\title{
Photoactivatable Prodrug-Backboned Polymeric Nanoparticles for Efficient Light-Controlled Gene Delivery and Synergistic Treatment of Platinum-Resistant Ovarian Cancer
}

Qingfei Zhang, ${ }^{\dagger,+}$ Gaizhen Kuang, ${ }^{\S}$ Shasha He, ${ }^{\dagger}$ Hongtong Lu, ${ }^{\dagger,+}$ Yilong Cheng, ${ }^{\&}$

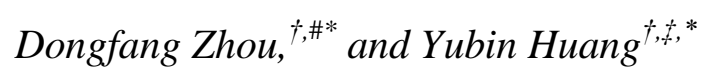

${ }^{\dagger}$ State Key Laboratory of Polymer Physics and Chemistry, Changchun Institute of Applied Chemistry, Chinese Academy of Sciences, Changchun 130022, P. R. China

$\$$ University of Science and Technology of China, Hefei 230026, P. R. China

${ }^{\S}$ Department of Medical Oncology, Affiliated Cancer Hospital of Zhengzhou University, Zhengzhou 450008, P. R. China

${ }^{\&}$ Department of Applied Chemistry, School of Science, Xi'an Jiaotong University, Xi'an 710049, P. R. China

\# School of Pharmaceutical Sciences, Southern Medical University, Guangzhou 510515, P. R. China

* Corresponding Authors:

Dongfang Zhou, E-mail: east@ciac.ac.cn; Phone: + 86-0431-85262538

Yubin Huang, E-mail: ybhuang@ ciac.ac.cn; Phone: + 86-0431-85262769 
TABLE OF CONTENTS

SUPPLEMENTAL MATERIALS AND METHODS .............................................4-28

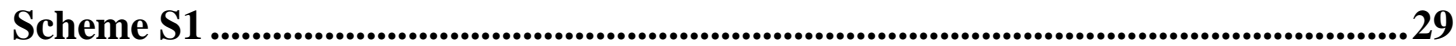

Figure S1 ..............................................................................................................................30

Figure S2 ..........................................................................................................................31

Figure S3 ............................................................................................................................32

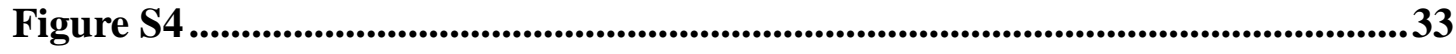

Figure S5 .......................................................................................................................34

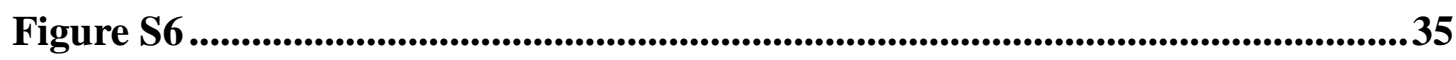

Figure S7 ..................................................................................................................36

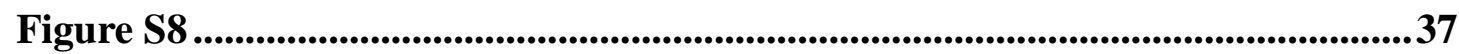

Figure S9...............................................................................................................38

Figure S10 ..................................................................................................................39

Figure S11 ................................................................................................................40

Figure S12 ..................................................................................................................41

Figure S13 ..................................................................................................................42

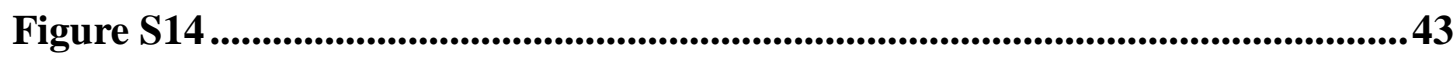

Figure S15 ...............................................................................................................44

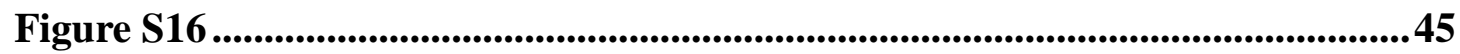

Figure S17 ..........................................................................................................................46

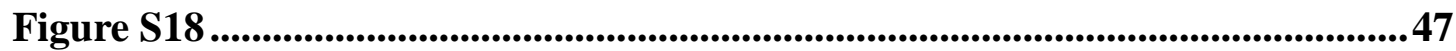

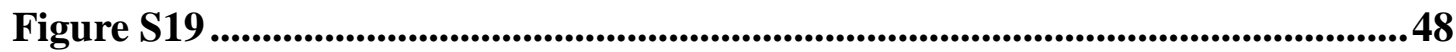

Figure S20 .................................................................................................................49

Figure S21 .....................................................................................................................50

Figure S22 ........................................................................................................................51

Figure S23 ......................................................................................................52

Figure S24 .....................................................................................................................53

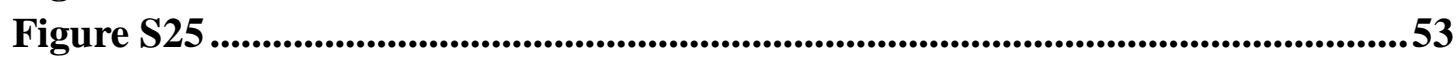

Figure S26 ........................................................................................................55-56

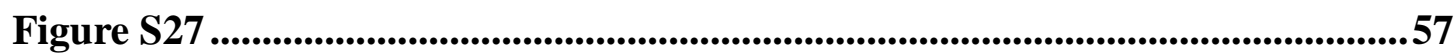

Figure S28 .............................................................................................................................58

Figure S29 ......................................................................................................................59

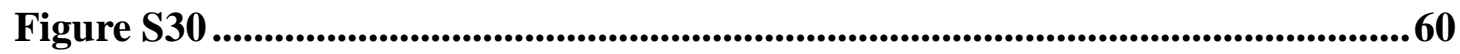

Figure S31 ....................................................................................................................61

Figure S32 .................................................................................................................62

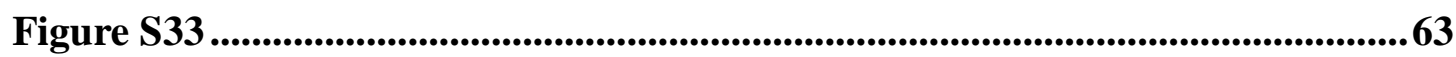

Figure S34 ..............................................................................................................64

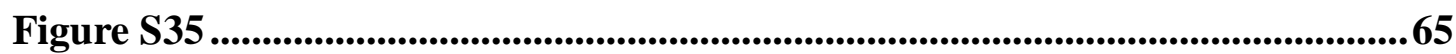

Figure S36 ............................................................................................................................66

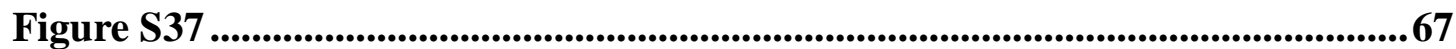

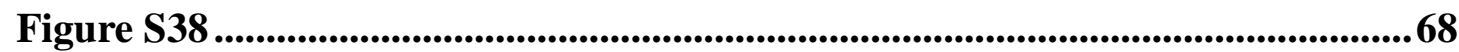

Figure S39 .................................................................................................................69

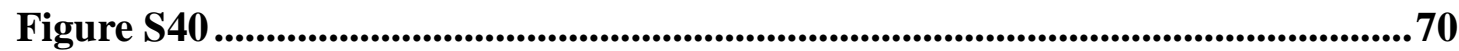

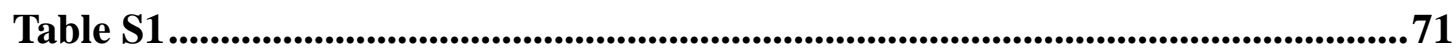




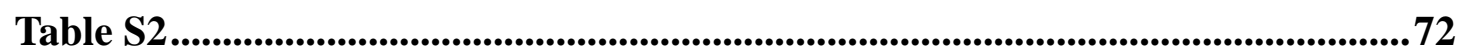

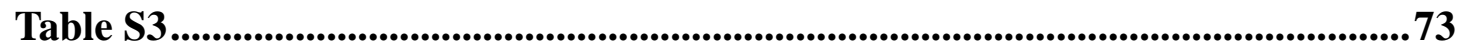

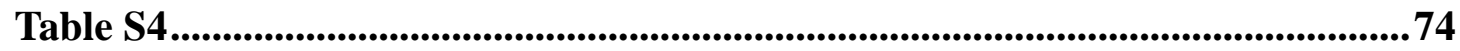




\section{SUPPLEMENTAL MATERIALS AND METHODS}

\section{Experimental section}

\section{Materials}

Cisplatin was bought from Shandong Boyuan Chemical Company, China. Branched oligomethylenimine (OEI) $(\mathrm{Mw} \sim 1800,99 \%)$, silver nitrate $\left(\mathrm{AgNO}_{3}\right)$, pyridine, sodium azide $\left(\mathrm{NaN}_{3}\right)$, hydrogen peroxide solution $\left(\mathrm{H}_{2} \mathrm{O}_{2}\right)$, 1-ethyl-3-[3-dimethylaminopropyl] carbodiimide hydrochloride $(\mathrm{EDC} \cdot \mathrm{HCl})$, N-hydroxysuccinimide (NHS) and tryptophan (Trp) were purchased from Aladdin. Sodium hyaluronate $(\mathrm{Mw} \sim 50 \mathrm{kDa})$ was purchased from Bloomage Freda Biopharm Co., Ltd. Guanosine 5'-monophosphate disodium salt and cyclobutane-1,2,3,4-tetracarboxylic dianhydride (CBTA) were purchased from Sanbang Medical Technology, China. 5,5-dimethyl-1-pyrroline N-oxide (DMPO), dichlorodihydrofluorescein diacetate (DCF-DA) and monomethoxy poly(ethylene glycol) (Mw 2000) was purchased from Sigma-Aldrich. Toluene and dimethyl sulfoxide (DMSO) were dried with calcium hydride for 7 days and then distilled under reduced pressure.

Hoechst 33258 and 3-(4,5-dimethylthiazol-2-yl)-2,5-diphenyltetrazolium bromide (MTT) were bought from Sigma-Aldrich. Enhanced bicinchoninic acid (BCA) protein assay kit, annexin V/PI apoptosis detection kit, acridine orange (AO), FITC-labeled goat anti-rabbit $\operatorname{IgG}(\mathrm{H}+\mathrm{L})$, horseradish peroxidase (HRP)-labeled goat anti-rabbit or anti-mouse secondary antibodies, enhanced electrochemiluminescence (ECL) western blotting detection reagents and diethylpyrocarbonate (DEPC) water were purchased 
from Beyotime Biotechnology, China. Heparin sodium, hematoxylin and eosin (H\&E) and animal tissues/cells genomic DNA extraction kit were purchased from Beijing Solarbio Science \& Technology Co., Ltd. Rabbit c-fos antibody and rabbit anti-phospho-histone H2AX (Ser139) antibody were purchased from Bioss Biotechnology Co., Ltd. Beijing, China. The DeadEnd" ${ }^{\mathrm{TM}}$ fluorometric TUNEL system for apoptosis detection was purchased from Promega Corporation. USA. Lyso-Tracker Red was bought from Invitrogen, USA. Calcein-AM/PI assay kit was purchased from Jiangsu KeyGEN Biotechnology Co., Ltd..

Small interfering RNAs (siRNAs) were purchased from GenePharma Co., Ltd., and the sequences were as follows: non-coding negative control siRNA (siNC) (sense, 5'-UUC UCC GAA CGU GUC ACG UTT-3'; antisense, 5'-ACG UGA CAC GUU CGG AGA ATT-3'); siRNA that targets c-fos mRNA (si(c-fos)) (sense, 5'-CAA GGU GGA ACA GUU AUC UTT-3'; antisense, 5'-AGA UAA CUG UUC CAC CUU GTT-3'). FAM or Cy3 labeled si(c-fos) were denoted as FAM-si(c-fos) or Cy3-si(c-fos). The control sequence did not match any human genome sequences.

\section{Measurements}

${ }^{1} \mathrm{H}-\mathrm{NMR}$ and ${ }^{13} \mathrm{C}-\mathrm{NMR}$ spectra were recorded at room temperature on a Bruker AVANCE DRX 400 spectrometer. Fourier Transform Infrared (FT-IR) measurements were performed on a Bruker Vertex70 Win-IR instrument. Electrospray ionization mass spectrometry (ESI-MS) measurements were conducted on a Watera Quattro Premier XE system. Inductively elemental analysis was measured on vario EL cube. Inductively coupled plasma mass spectrometry (ICP-MS, Xseries II, Thermoscientific, 
USA) was used for quantitative determination of platinum content. The molecular weight and polydispersity index of the synthetic polymers were determined by a gel permeation chromatograph (GPC) instrument. The oxidation state of Pt was identified by X-ray photoelectron spectroscopy (XPS, Thermo ESCALAB 250). Transmission electron microscopy (TEM) images were taken on JEOL JEM-1011 electron microscope with an acceleration voltage of $100 \mathrm{kV}$. Diameter and zeta potential were recorded by dynamic light scattering (DLS) using Malvern Zetasizer Nano ZS90 (Malvern instruments, UK). UV-visible absorption spectra were measured on a Varian Cary 300 UV-visible spectrophotometer. Visible light irradiation was performed by a xenon lamp source (CEL-S500, AuLight, China) equipped with a filter (365, 430 or $530 \mathrm{~nm}$ ) for a parallel light. The power outage was determined by a powermeter (FZ-A, AuLight, China). In vitro cellular and histological fluorescence imaging were observed on confocal laser scanning microscope (CLSM) imaging system (Zeiss710, Japan). Clinic parameters were measured by an automatic biochemical analyzer (Mindray BS-220, China). BioTek Cytation ${ }^{\mathrm{TM} 5}$ automated imaging and multi-mode microplate reading in one configurable instrument was used for cell viability assessment and histological section imaging observation. Western blotting assays were detected using an Imager (Tanon 5200). Quantitative analysis of cellular uptake was recorded by flow cytometry imaging system (Amnis).

\section{Synthesis and Characterization}

\section{Synthesis of trans,trans,trans-[Pt( $\left.\left.\mathbf{N}_{3}\right)_{2}(\mathrm{OH})_{2}(\mathbf{p y})\left(\mathbf{N H}_{3}\right)\right](\operatorname{Pt}(\mathrm{IV}))$}

$\mathrm{Pt}(\mathrm{IV})$ was synthesized according to the previous reference. ${ }^{1}$ Briefly, cisplatin $(0.9$ 
mg, $3 \mathrm{mmol}$ ) was suspended in $\mathrm{H}_{2} \mathrm{O}(50 \mathrm{~mL})$. Pyridine (py) $(2.37 \mathrm{~g}, 30 \mathrm{mmol})$ was added to the solution. After stirring at $75{ }^{\circ} \mathrm{C}$ for $2 \mathrm{~h}$, the clear solution was obtained and evaporated under high vacuum to get a white compound. The solution of $\mathrm{HCl}(2$ $\mathrm{M}, 10 \mathrm{~mL})$ in $\mathrm{H}_{2} \mathrm{O}(50 \mathrm{~mL})$ was added to above compound and stirred at $75{ }^{\circ} \mathrm{C}$ for 4 days. After cooling on ice, the yellow solid was filtered off, washed with minimal cold water, ethanol and diethyl ether and dried under vacuum to obtain trans- $\left[\mathrm{PtCl}_{2}\left(\mathrm{NH}_{3}\right)(\mathrm{py})\right]$. Trans- $\left[\mathrm{PtCl}_{2}\left(\mathrm{NH}_{3}\right)(\mathrm{py})\right]$ (1.086 g, 3 mol) was suspended in water $(50 \mathrm{~mL})$ and then $\mathrm{AgNO}_{3}(1.019 \mathrm{~g}, 6 \mathrm{~mol})$ was added. The suspension was stirred at room temperature for $24 \mathrm{~h}$ in the dark and filtrated to get a clear solution. $\mathrm{NaN}_{3}(0.39 \mathrm{~g}, 6 \mathrm{mmol})$ was added to the solution and stirred for another $6 \mathrm{~h}$ in the dark to get yellow precipitate. Then the yellow precipitate was filtered off, washed with minimal cold water, ethanol and diethyl ether and dried under vacuum to get trans- $\left[\mathrm{Pt}\left(\mathrm{N}_{3}\right)_{2}\left(\mathrm{NH}_{3}\right)(\mathrm{py})\right] . \quad$ Finally, trans, trans, trans- $\left[\mathrm{Pt}\left(\mathrm{N}_{3}\right)_{2}(\mathrm{OH})_{2}\left(\mathrm{NH}_{3}\right)(\mathrm{py})\right]$ was prepared by suspending trans- $\left[\mathrm{Pt}\left(\mathrm{N}_{3}\right)_{2}\left(\mathrm{NH}_{3}\right)(\mathrm{py})\right](0.75 \mathrm{~g}, 2 \mathrm{mmol})$ in $\mathrm{H}_{2} \mathrm{O}(30 \mathrm{ml})$ and adding $\mathrm{H}_{2} \mathrm{O}_{2}(20 \mathrm{~mL}, 30 \%)$. After stirring overnight at room temperature in the dark, the solution was filtrated and lyophilized to get the yellow powder product. ${ }^{1} \mathrm{H}$ NMR (400 MHz, DMSO-d ${ }^{6}$, ppm): 9.08 (a, NCH), 8.21 (c, CH), 7.81 (b, CH), 5.64 (d, $\mathrm{NH}_{3}$ ). ${ }^{1} \mathrm{H}$ NMR (400 MHz, D $\left.2 \mathrm{O}, \mathrm{ppm}\right): 8.63(\mathrm{a}, \mathrm{NCH}), 8.16$ (c, CH), 7.69 (b, CH). IR $\left(\mathrm{cm}^{-1}\right)$ : 3660-3160 (br, $\mathrm{NH}_{3}$ and $\left.\mathrm{OH}\right), 3080$ (sh, CH), 2040 (sh, $\mathrm{N}_{3}$ ), 560 (sh, Pt-OH). ESI-MS (m/z): $[\mathrm{M}+\mathrm{Na}]^{+}$432.1. Element analysis calculated for $\mathrm{C}_{5} \mathrm{H}_{10} \mathrm{~N}_{8} \mathrm{O}_{2} \mathrm{Pt}$ : C 14.67, H 2.44, N 27.38; Found C 15.55, H 2.45, N 27.22. ICP-OES analysis calculated for Pt 47.68; Found 47.52. 
*Caution!* Although no problems occurred during this process, heavy metal azides were heat and shock-sensitive detonators. Therefore, any platinum azide compounds must be handled carefully.

\section{Synthesis of photoactivatable Pt(IV) prodrug-backbone cationic polymer (PtCP)}

$\mathrm{PtCP}$ was synthesized using one-pot reaction. In general, $\mathrm{Pt}(\mathrm{IV})(94.2 \mathrm{mg}, 0.2$ mmol) and CBTA (39.2 mg, $0.2 \mathrm{mmol}$ ) were dissolved in dried DMSO (10 mL), and the solution was stirred at $60{ }^{\circ} \mathrm{C}$ for 3 days in dark condition. After cooling to room temperature, $1 \mathrm{~mL}$ of the reaction solution was extracted and precipitated in diethyl ether to obtain the photoactivatable $\mathrm{Pt}(\mathrm{IV})$ prodrug-backbone polymer (PtP). The number-average molecular weight $(M n)$ of PtP was measured by GPC. EDC $\cdot \mathrm{HCl}$ (153.4 $\mathrm{mg}, 0.8 \mathrm{mmol})$ and NHS $(92.0 \mathrm{mg}, 0.8 \mathrm{mmol})$ were added to the remanent reaction solution and stirred for $2 \mathrm{~h}$, and then $\mathrm{OEI}_{1.8 \mathrm{~K}}(100 \mathrm{mg}, 0.056 \mathrm{mmol})$ in DMSO (2 mL) was added and continuously stirred for another $48 \mathrm{~h}$ in the dark. The crude product was purified by dialyzing against deionized water using spectra/por regenerated cellulose membrane $(\mathrm{MwCO}=7000)$ for 3 days. The solution was lyophilized to get the final product PtCP. Characterization of PtP, ${ }^{1} \mathrm{H}$ NMR (400 MHz, DMSO-d $\left.{ }^{6}, \mathrm{ppm}\right): 12.47$ (g, COOH), $8.63(\mathrm{a}, \mathrm{NCH}), 8.16$ (c, CH), 7.69 (b, CH), 6.68 (f, $\left.\mathrm{NH}_{3}\right), 3.50(\mathrm{~d}+\mathrm{e}, \mathrm{CHCH})$. ICP-OES analysis calculated for Pt 31.98; Found 30.12. The number-average molecular weight $(M n)$ of PtP was determined by GPC to be $63.4 \times 10^{3} \mathrm{~g} \mathrm{~mol}^{-1}(\mathrm{Mw} / \mathrm{Mn}=1.11)$ and the mean degree of polymerization was 104. Characterization of PtCP, ${ }^{1} \mathrm{H}$ NMR (400 MHz, DMSO-d ${ }^{6}$, ppm): 8.73 (a, NCH), 8.18 (c, $\mathrm{CH}), 7.75(\mathrm{~b}, \mathrm{CH}), 3.30(\mathrm{~d}+\mathrm{e}, \mathrm{CHCH}), 3.20-2.10\left(\mathrm{CH}_{2} \mathrm{CH}_{2}\right.$ of $\left.\mathrm{OEI}\right)$. The 
number-average molecular weight $(M n)$ of PtCP was determined by GPC to be $99.2 \times$ $10^{3} \mathrm{~g} \mathrm{~mol}^{-1}(\mathrm{Mw} / \mathrm{Mn}=1.14)$ and the grafted $\mathrm{OEI}_{1.8 \mathrm{~K}}$ number was $20 . \mathrm{IR}\left(\mathrm{cm}^{-1}\right): 3560$, 3440, 3250 (br, $\mathrm{NH}_{3}, \mathrm{NH}_{2}$ and $\mathrm{OH}$ ), 3050 (sh, $\mathrm{CH}$ ), 2030 (sh, $\mathrm{N}_{3}$ ), 565 (sh, Pt-OH). ICP-OES analysis calculated for Pt 20.44; Found 16.80.

\section{Synthesis of rhodamine B (RhB)-labelled PtCP (RhB-PtCP)}

RhB (19.2 mg, $0.04 \mathrm{mmol}), \mathrm{EDC} \cdot \mathrm{HCl}(15.3 \mathrm{mg}, 0.08 \mathrm{mmol})$ and NHS (18.4 mg, $0.08 \mathrm{mmol})$ were dissolved in $5 \mathrm{~mL}$ DMSO. After stirring for $60 \mathrm{~min}, \mathrm{PtCP}(100 \mathrm{mg})$ in $5 \mathrm{~mL}$ of DMSO was added. The mixed solution was continuously stirred for another $24 \mathrm{~h}$ at room temperature. The final solution was dialyzed $(\mathrm{MwCO}=7000)$ against deionized water for $72 \mathrm{~h}$ to remove unreacted RhB and DMSO and then freeze-dried for further usage. The yield of RhB-PtCP was about $80 \%$.

\section{Synthesis of $\mathbf{m P E G}_{2 \mathrm{k}}-\mathrm{NH}_{2}$}

Triethylamine (TEA, $0.202 \mathrm{~g}, 2 \mathrm{mmol}$ ) was injected to the solution of $\mathrm{mPEG}_{2 \mathrm{k}}-\mathrm{OH}$ (2 g, $1 \mathrm{mmol}$ ) in $\mathrm{CH}_{2} \mathrm{Cl}_{2}$ (40 mL). Methylsufonyl chloride was dropwise added to above solution with constant pressure liquid funnel under stirring at ice bath in $1 \mathrm{~h}$. After stirring for another $24 \mathrm{~h}$, the reaction solution was concentrated by vacuum rotary evaporation, and the residual mixture was poured into $500 \mathrm{~mL}$ of cold diethyl ether to obtain a white precipitate. The white precipitate was filtered and dried under vacuum to obtain $\mathrm{mPEG}_{2 \mathrm{k}}-\mathrm{OMs}$. $\mathrm{mPEG}_{2 \mathrm{k}}-\mathrm{OMs}$ was redissolved in $100 \mathrm{~mL} \mathrm{NH}{ }_{3} \cdot \mathrm{H}_{2} \mathrm{O}$ with $2 \mathrm{~g} \mathrm{NH}_{4} \mathrm{Cl}$. After stirring at room temperature for 3 days, the solution was extracted with total $200 \mathrm{~mL} \mathrm{CH} \mathrm{Cl}_{2}$ for three times. The obtained organic phase was washed with a small amount of saturated $\mathrm{NaCO}_{3}, \mathrm{KHSO}_{4}$ and $\mathrm{NaCl}$ solution for three 
times, respectively, and then dried with anhydrous $\mathrm{MgSO}_{4}$. After filtration, the organic phase was concentrated by vacuum rotary evaporation, and the residual mixture was precipitated in $200 \mathrm{~mL}$ of cold diethyl ether. Finally, the product of $\mathrm{mPEG}_{2 \mathrm{k}}-\mathrm{NH}_{2}$ was isolated by filtration and dried under vacuum.

\section{Synthesis of HA-PEG (HP)}

Sodium hyaluronate $(100 \mathrm{mg}), \mathrm{EDC} \cdot \mathrm{HCl}(38.3 \mathrm{mg})$ and NHS $(23 \mathrm{mg})$ were dissolved in $50 \mathrm{~mL}$ water to active carboxyl groups for $2 \mathrm{~h}$. Then $\mathrm{mPEG}_{2 \mathrm{k}}-\mathrm{NH}_{2}(100$ $\mathrm{mg}$ ) in $2 \mathrm{~mL}$ water was added, and the solution was allowed to react for another $24 \mathrm{~h}$. The product HA-PEG was dialyzed against deionized water using cellulose membrane $(\mathrm{MwCO}=14000)$ and lyophilized for further use.

\section{Light source and irradiation conditions}

Irradiations were carried out using a xenon lamp source (CEL-S500, AuLight, China) equipped with filters for a parallel monochromatic light at $365 \mathrm{~nm}, 430 \mathrm{~nm}$ or $530 \mathrm{~nm}$. The power outage of light was measured at $20 \mathrm{~mW} / \mathrm{cm}^{2}$ using a power meter (FZ-A, AuLight, China). The irradiation time was conducted according to the requirements of different experiments.

\section{Preparation and photosensitivity of PtCP nanoparticles (NPPtCP)}

$\mathrm{NP}_{\mathrm{PtCP}}$ were prepared by a nanoprecipitation method. Briefly, the lyophilized product of PtCP $(30 \mathrm{mg})$ was dissolved in DMSO $(5 \mathrm{~mL})$, and then water $(30 \mathrm{~mL})$ was dropwise added into it under stirring to obtain a micellar solution. The solution was dialyzed against deionized water and freeze-dried. The morphology of the nanoparticle was observed from TEM and the size was measured by DLS. The 
platinum content of the nanoparticle was measured by ICP-OES.

Aqueous solutions of $\mathrm{Pt}(\mathrm{IV})$ and $\mathrm{NP}_{\mathrm{PtCP}}$ were irradiated $(365 \mathrm{~nm}, 430 \mathrm{~nm}, 530 \mathrm{~nm}$, $20 \mathrm{~mW} / \mathrm{cm}^{3}$ ) for the indicated time intervals, and the corresponding UV-Vis spectra were measured. The morphology and size distribution changes of $\mathrm{NP}_{\mathrm{PtCP}}$ were also monitored by TEM and DLS, respectively.

Aqueous solutions of $\mathrm{Pt}(\mathrm{IV})$ and $\mathrm{NP}_{\mathrm{PtCP}}$ were irradiated $\left(430 \mathrm{~nm}, 20 \mathrm{~mW} / \mathrm{cm}^{3}\right)$ for 60 min and lyophilized for XPS measurement.

PtCP was dissolved in DMSO and the solution was irradiated $\left(430 \mathrm{~nm}, 20 \mathrm{~mW} / \mathrm{cm}^{3}\right)$ for 0 or $60 \mathrm{~min}$, then the number-average molecular weight $(\mathrm{Mn})$ changes of PtCP were measured by GPC.

\section{Buffering capacity of PtCP}

Acid-base titration was used to determinate the buffering capacity of PtCP according to the reference. ${ }^{2}$ In details, $12 \mathrm{mg}$ of $\mathrm{PtCP}$ was dissolved in $\mathrm{NaCl}$ solution $(150 \mathrm{mM})$ and alkalized with $0.1 \mathrm{M}$ of $\mathrm{NaOH}$ solution to $\mathrm{pH} 10.0$, which was adjusted to a final volume of $10 \mathrm{~mL}$ with deionized water at the final concentration of 1.2 $\mathrm{mg} / \mathrm{mL} \mathrm{PtCP}(10 \mathrm{mM}$ nitrogen atoms). The solution was titrated slowly with $\mathrm{HCl}$ solution $(0.1 \mathrm{M})$ at $37^{\circ} \mathrm{C}$, and the $\mathrm{pH}$ value of the solution was recorded until the final $\mathrm{pH}$ value was $2.0 . \mathrm{NaCl}$ solution $(150 \mathrm{mM})$ and $\mathrm{OEI}(10 \mathrm{mM}$ nitrogen atoms $)$ were also titrated accordingly for comparison. The buffering capacity of PtCP was calculated according to the equation as below:

$$
\text { Buffering capability }=\Delta \mathrm{V}(\mathrm{HCl}) \times \frac{0.1 \mathrm{M}}{\mathrm{N} \mathrm{mol}} \times 100 \%
$$

$\Delta \mathrm{V}(\mathrm{HCl})$ : the volume of $\mathrm{HCl}(0.1 \mathrm{M})$ used for titration from $\mathrm{pH} 7.4$ to 5.0. $\mathrm{N} \mathrm{mol}$ : 
the moles of nitrogen atoms of PtCP in solution.

\section{Preparation and characterization of $\mathbf{N P}_{\mathbf{P t C P} / \mathrm{si} \text { (c-fos) }}$}

$\mathrm{NP}_{\mathrm{PtCP}}$ were dissolved in DEPC water at various concentrations, then the si(c-fos) solutions were added, and the solutions were vortexed for 10 seconds to produce $\mathrm{NP}_{\mathrm{PtCP} / \mathrm{si}(\mathrm{c}-\mathrm{fos})}$ at various weigh ratios of PtCP to si(c-fos) $\left(\mathrm{W}_{\mathrm{PtCP}} / \mathrm{W}_{\mathrm{si} \text { (c-fos })}\right)$. Then the solutions were incubated at room temperature away from light for $30 \mathrm{~min}$ before further characterization. si(c-fos) binding ability was evaluated by gel retardation assay. The complex nanoparticles of $\mathrm{NP}_{\mathrm{PtCP} / \mathrm{si}(\mathrm{c}-\mathrm{fos})}$ were electrophoresed on a $1 \%$ agarose gel at a constant voltage of $100 \mathrm{~V}$ for $30 \mathrm{~min}$ in tris acetate-EDTA buffer. The si(c-fos) bands were stained with ethidium bromide (EB) and visualized under an ultraviolet transilluminator. The morphology of $\mathrm{NP}_{\mathrm{PtCP} / \mathrm{si}(\mathrm{c}-\mathrm{fos})}$ was visualized using TEM and the size and zeta potential were measured by DLS measurement.

\section{Preparation and characterization of $\mathrm{CNP}_{\mathrm{PtCP} / \mathrm{si} \text { (c-fos) }}$}

$\mathrm{NP}_{\mathrm{PtCP} / \mathrm{si}(\mathrm{c}-\mathrm{fos})}$ were prepared at the optimal weight ratios of $20\left(\mathrm{~W}_{\mathrm{PtCP}} / \mathrm{W}_{\mathrm{si}(\mathrm{c}-\mathrm{fos})}=20\right)$, then a certain volume of HP solutions were added at various weigh ratios of HP to $\mathrm{PtCP}\left(\mathrm{W}_{\mathrm{HP}} / \mathrm{W}_{\mathrm{PtCP}}\right)$ and incubated for $30 \mathrm{~min}$ to get $\mathrm{CNP}_{\mathrm{PtCP} / \mathrm{si}(\mathrm{c}-\mathrm{fos})}$. The size and zeta potential of $\mathrm{CNP}_{\mathrm{PtCP} / \mathrm{si}(\mathrm{c}-\text { fos })}$ were measured by DLS, and the morphology was observed by TEM. Gel retardation assay was used for evaluating the stability of the si(c-fos) in $\mathrm{CNP}_{\mathrm{PtCP} / \mathrm{si} \text { (c-fos). }}$

To investigate loading efficiency of si(c-fos) in $\mathrm{CNP}_{\mathrm{PtCP} / \mathrm{si}(\mathrm{c}-\mathrm{fos})}$, the nanoparticles of $\mathrm{CNP}_{\mathrm{PtCP} / \mathrm{Cy} 3 \text {-si(c-fos) }}\left(\mathrm{W}_{\mathrm{PtCP}} / \mathrm{W}_{\mathrm{Cy} 3 \text {-si(c-fos })}=20, \mathrm{~W}_{\mathrm{HP}} / \mathrm{W}_{\mathrm{PtCP}}=5\right)$ was prepared according to above method. After the formation of $\mathrm{CNP}_{\mathrm{PtCP} / \mathrm{Cy} 3 \text {-si(c-fos), the nanoparticle was }}$ 
centrifuged at $15000 \mathrm{rpm}$ for $30 \mathrm{~min}$, and the weight of Cy3-si(c-fos) in the supernatant can be quantified by the UV-vis spectrum. The loading efficiency of si(c-fos) can be determined before and after the formation of $\mathrm{CNP}_{\mathrm{PtCP} / \mathrm{Cy} 3-\mathrm{si}(\mathrm{c}-\mathrm{fos}) \text {, and }}$ calculated by the following equation: $\mathrm{LE} \%=[($ total $\mathrm{Cy} 3-\mathrm{si}(\mathrm{c}-\mathrm{fos})-$ free Cy3-si(c-fos))/total Cy3-si(c-fos)] * 100.

\section{Anti-anion displacement assay}

$\mathrm{NP}_{\mathrm{PtCP} / \mathrm{si}(\mathrm{c}-\mathrm{fos})}\left(\mathrm{W}_{\mathrm{PtCP}} / \mathrm{W}_{\mathrm{si}(\mathrm{c}-\mathrm{fos})}=20\right)$ and $\mathrm{CNP}_{\mathrm{PtCP} / \mathrm{si} \text { (c-fos })}\left(\mathrm{W}_{\mathrm{PtCP}} / \mathrm{W}_{\mathrm{si} \text { (c-fos })}=20, \mathrm{~W}_{\mathrm{HP}} /\right.$ $\mathrm{W}_{\mathrm{PtCP}}=5$ ) were incubated with heparin sodium in a series of weight ratios of heparin to $\mathrm{si}$ (c-fos) $\left(\mathrm{W}_{\text {heparin }} / \mathrm{W}_{\mathrm{si}(\mathrm{c}-\mathrm{fos})}\right)$ for $30 \mathrm{~min}$ at room temperature and analyzed using gel retardation assay.

\section{Stability of NP $\mathrm{PtCP}_{\mathbf{P}}, \mathrm{NP}_{\mathrm{PtCP} / \mathrm{si}(\mathrm{c}-\mathrm{fos})}$ and $\mathrm{CNP}_{\mathbf{P t C P} / \mathrm{si}(\mathrm{c}-\mathrm{fos})}$}

The same concentration and volume solutions of $\mathrm{NP}_{\mathrm{PtCP}}, \mathrm{NP}_{\mathrm{PtCP} / \mathrm{si} \text { (c-fos })}$ and $\mathrm{CNP}_{\mathrm{PtCP} / \mathrm{si} \text { (c-fos) }}$ were added to PBS or RPMI-1640 medium (with 10\% FBS) and incubated for predetermined time points, respectively, and the size and size distribution were measured by DLS.

For anti-protein adsorption assay, $1 \mathrm{~mL}$ of $\mathrm{NP}_{\mathrm{PtCP}}, \mathrm{NP}_{\mathrm{PtCP} / \mathrm{si}(\mathrm{c}-f \circ s)}$ or $\mathrm{CNP}_{\mathrm{PtCP} / \mathrm{si}(\mathrm{c}-f o s)}$ solutions $(1 \mathrm{mg} / \mathrm{mL})$ were mixed with $0.5 \mathrm{~mL}$ of bovine serum albumin (BSA) solutions $(2 \mathrm{mg} / \mathrm{mL})$. After timed incubation at $37{ }^{\circ} \mathrm{C}$, the mixtures were centrifuged at $4{ }^{\circ} \mathrm{C}$ with $12000 \mathrm{rpm}$. The supernatant fraction was collected, and the BSA concentrations were detected using BCA protein assay kit and the percentages of residual BSA were calculated.

\section{The inertness of $\mathrm{Pt}(\mathrm{IV})$}


To verify the stability of Pt(IV) when co-delivering with si(c-fos), the interaction of $\mathrm{Pt}(\mathrm{IV})$ and single-stranded si(c-fos) (ss-si(c-fos)) or gene mimic 5'-GMP was investigated, the divalent intermediate trans, trans-[Pt( $\left.\left.\mathrm{NH}_{3}\right)(\mathrm{Py})\left(\mathrm{NO}_{3}\right)_{2}\right]\left(\mathrm{Pt}(\mathrm{II})-\mathrm{NO}_{3}\right)$ and cisplatin were selected as control.

$\mathrm{Pt}(\mathrm{IV})$ or $\mathrm{Pt}(\mathrm{II})-\mathrm{NO}_{3}$ were prepared in $\mathrm{D}_{2} \mathrm{O}$ at the final of $\mathrm{Pt}$ concentration as 10 $\mathrm{mM}$, and then mixed with 5'-GMP $\mathrm{D}_{2} \mathrm{O}$ solution $(20 \mathrm{mM})$. After being incubated in a $37{ }^{\circ} \mathrm{C}$ thermostatic shaker for predetermined time points, the reaction of $\mathrm{Pt}(\mathrm{IV})$ or $\mathrm{Pt}(\mathrm{II})-\mathrm{NO}_{3}$ with 5'-GMP were monitored by ${ }^{1} \mathrm{H}-\mathrm{NMR}$ spectra and ESI-MS.

Ss-si(c-fos) $(100 \mu \mathrm{M})$ in diethy pyrocarbonate (DEPC) water $(10 \mu \mathrm{L})$ was mixed with $\mathrm{Pt}(\mathrm{IV})(1 \mathrm{mM} \mathrm{Pt})$ or cisplatin $(1 \mathrm{mM} \mathrm{Pt})$ in DEPC water $(10 \mu \mathrm{L})$, respectively. After incubation in a $37^{\circ} \mathrm{C}$ thermostatic shaker for $1,6,12$, and $24 \mathrm{~h}, 1 \mu \mathrm{L}$ of the mixture solution was withdrawn for matrix-assisted laser desorption/ionization time of flight mass spectrometry (MALDI/TOF-MS) measurement, respectively.

\section{Photosensitivity of NP $P_{\mathrm{PtCP} / \mathrm{si}(\mathrm{c}-\mathrm{fos})}$ and $\mathrm{CNP}_{\mathrm{PtCP} / \mathrm{si}(\mathrm{c}-\mathrm{fos})}$}

The same concentration and volume solutions of $\mathrm{NP}_{\mathrm{PtCP} / \mathrm{si} \text { (c-fos) }}$ and $\mathrm{CNP}_{\mathrm{PtCP} / \mathrm{si} \text { (c-fos) }}$ $\left(\mathrm{W}_{\mathrm{PtCP}} / \mathrm{W}_{\mathrm{si}(\mathrm{c}-\mathrm{fos})}=20, \mathrm{~W}_{\mathrm{HP}} / \mathrm{W}_{\mathrm{PtCP}}=5\right)$ were dissolved in water and irradiated $(430 \mathrm{~nm}$, $20 \mathrm{~mW} / \mathrm{cm}^{3}$ ) for the indicated time intervals, respectively, and the corresponding morphology and size distribution changes of $\mathrm{NP}_{\mathrm{PtCP} / \mathrm{si}(\mathrm{c}-\mathrm{fos})}$ and $\mathrm{CNP}_{\mathrm{PtCP} / \mathrm{si}(\mathrm{c}-\mathrm{fos})}$ were monitored by TEM and DLS.

Gel retardation assay was used for monitoring the disassembly of $\mathrm{NP}_{\mathrm{PtCP} / \mathrm{si}(\mathrm{c}-\mathrm{fos})}$ and $\mathrm{CNP}_{\mathrm{PtCP} / \mathrm{si} \text { (c-fos). }}$ In details, aqueous solutions of $\mathrm{NP}_{\mathrm{PtCP} / \mathrm{si}(\mathrm{c}-\text { fos })}\left(\mathrm{W}_{\mathrm{PtCP}} / \mathrm{W}_{\mathrm{si}(\mathrm{c}-\mathrm{fos})}=20\right)$ and $\mathrm{CNP}_{\mathrm{PtCP} / \mathrm{si}(\mathrm{c}-\mathrm{fos})}\left(\mathrm{W}_{\mathrm{PtCP}} / \mathrm{W}_{\mathrm{si}(\mathrm{c}-\mathrm{fos})}=20, \mathrm{~W}_{\mathrm{HP}} / \mathrm{W}_{\mathrm{PtCP}}=5\right)$ were irradiated $(430 \mathrm{~nm}, 20$ 
$\mathrm{mW} / \mathrm{cm}^{3}$ ) for indicated time intervals, respectively, and electrophoresed on a $1 \%$ agarose gel at a constant voltage of $100 \mathrm{~V}$ for $30 \mathrm{~min}$ in tris acetate-EDTA buffer. The released si(c-fos) was visualized under an ultraviolet transilluminator.

\section{Detection of azidyl radical $\left(\mathrm{N}_{3}{ }^{\circ}\right)$}

Firstly, ${ }^{1} \mathrm{H}-\mathrm{NMR}$ spectra were used to detect the $\mathrm{N}_{3}$ generated from $\mathrm{Pt}(\mathrm{IV})$ or PtCP. In details, $\mathrm{Pt}(\mathrm{IV})$ and $\mathrm{PtCP}$ were dissolved in $\mathrm{D}_{2} \mathrm{O}$ at the final $\mathrm{Pt}$ concentration of 10 $\mathrm{mM}$, then added to the DMPO solution $(20 \mathrm{mM})$ in the absence or presence of $\operatorname{Trp}(2$ $\mathrm{mM}$ ), respectively. The obtained solutions were divided into dark group (the one maintained in the dark all the time) and irradiation group (the one irradiated for 30 min). At last, all the samples in $\mathrm{D}_{2} \mathrm{O}$ were measured by ${ }^{1} \mathrm{H}-\mathrm{NMR}$.

DCF-DA was then used to detect the $\mathrm{N}_{3}{ }^{\circ}$ generated from $\mathrm{CNP}_{\mathrm{PtCP} / \mathrm{si} \text { (c-fos) }}$ in aqueous solution and in vitro. $\mathrm{N}_{3}{ }^{\circ}$ can oxidized the non-fluorescent DCF-DA to its fluorescent product of DCF. For aqueous solution detection, the DCF-DA in DMSO was added to $1 \mathrm{~mL}$ of $0.01 \mathrm{M} \mathrm{NaOH}$ at the final concentration of DCF-DA as $0.4 \mathrm{mM}$ and allowed to stir for $30 \mathrm{~min}$. Then the hydrolysate was added to $10 \mathrm{~mL} \mathrm{PBS}$ at $\mathrm{pH} 7.4$ and stored on ice for further use. $100 \mu \mathrm{L}$ of the above solution was mixed with $2 \mathrm{~mL}$ of $\mathrm{CNP}_{\mathrm{PtCP} / \mathrm{si} \text { (c-fos })}(0.1 \mathrm{mg} / \mathrm{mL})$ and irradiated for different time intervals. The fluorescence change was measured upon excitation at $488 \mathrm{~nm}$ and the emission was collected from 510 to $600 \mathrm{~nm}$. For intracellular detection, A2780 ${ }^{\mathrm{DDP}}$ cells were seeded in 6-well plates at a density of $2.5 \times 10^{5}$ cells per well and incubated overnight. The medium was replaced with fresh medium with $\mathrm{CNP}_{\mathrm{PtCP} / \mathrm{si} \text { (c-fos })}(\mathrm{Pt}$ : $10.8 \mu \mathrm{M}, \mathrm{RNA}$ : $0.625 \mu \mathrm{g} / \mathrm{mL}$ ) in the absence or presence of Vitamin C (VC) and incubated for $4 \mathrm{~h}$. 
The medium was then replaced with medium containing $10 \mu \mathrm{M}$ DCF-DA and incubated for another $20 \mathrm{~min}$. The cells were washed with medium and treated with or without irradiation before CLSM observation.

\section{The influence of $\mathrm{N}_{3}{ }^{\circ}$ to genes}

The influence of $\mathrm{N}_{3}{ }^{\circ}$ to si(c-fos) was measured by agarose gel electrophoresis and MALDI/TOF-MS. For agarose gel electrophoresis measurement, $\mathrm{CNP}_{\mathrm{PtCP} / \mathrm{si}(\mathrm{c}-\mathrm{fos})}$ $\left(\mathrm{W}_{\mathrm{PtCP}} / \mathrm{W}_{\mathrm{si}(\mathrm{c}-\mathrm{fos})}=20, \mathrm{~W}_{\mathrm{HP}} / \mathrm{W}_{\mathrm{PtCP}}=5\right)$ were dissolved in water and irradiated for 0,10 , 20, and 30 min. After irradiation, the si(c-fos) in $\mathrm{CNP}_{\mathrm{PtCP} / \mathrm{si}(\mathrm{c}-\mathrm{fos})}$ was displaced by the addition of sodium heparin and the si(c-fos) bands were observed using agarose gel electrophoresis. Instead of si(c-fos), the plasmid DNA (pDNA) was also used to detect the influence of $\mathrm{N}_{3}{ }^{\circ}$ to genes.

For MALDI/TOF-MS measurement, single strand si(c-fos) (ss-si(c-fos)) (100 $\mu \mathrm{M})$ was added with different concentrations of iodobenzene diacetate and sodium azide $(0$, 1 and $10 \mu \mathrm{M})$ or $\mathrm{Pt}(\mathrm{IV})(0,1$ and $10 \mu \mathrm{M})$. The mixed solution of ss-si(c-fos) and Pt(IV) was irradiated for $30 \mathrm{~min}$, and then the molecular weight of the ss-si(c-fos) was measured by matrix-assisted laser desorption/ionization time of flight mass spectrometry (MALDI/TOF-MS). Using the same method, the molecular weight of UGG (a model ss-oligonucleotide of si(c-fos)) was also measured by ESI-MS to detect the influence of $\mathrm{N}_{3}{ }^{\circ}$ to genes.

Besides, 2D $\left[{ }^{1} \mathrm{H},{ }^{13} \mathrm{C}\right]$ HSQC NMR spectrum was used to investigate the influence of $\mathrm{N}_{3}{ }^{\circ}$ to 5'-GMP. Pt(IV) (20.45 mg) and 5'-GMP were dissolved in $1 \mathrm{~mL} \mathrm{D}_{2} \mathrm{O}$ and the solution was irradiation for 0,15 and 30 min before being monitored by NMR 
spectrum.

\section{Photoresponsive platinum $(\mathbf{P t})$ and si(c-fos) release}

For platinum release measurement, the DEPC water solutions of Cy3-si(c-fos) contained $\mathrm{CNP}_{\mathrm{PtCP} / \mathrm{Cy} 3-\mathrm{si}(\mathrm{c}-\text { fos })}\left(2 \mathrm{mg}\right.$ of $\left.\mathrm{PtCP}, \mathrm{W}_{\mathrm{PtCP}} / \mathrm{W}_{\mathrm{si} \text { (c-fos) }}=20, \mathrm{~W}_{\mathrm{HP}} / \mathrm{W}_{\mathrm{PtCP}}=5\right)$ with or without pre-irradiated $\left(430 \mathrm{~nm}, 20 \mathrm{~mW} / \mathrm{cm}^{3}\right)$ for $30 \mathrm{~min}$ were introduced in a pre-swelled dialysis bag $(\mathrm{MwCO}=1000)$ and immersed into corresponding DEPC water solution $(19 \mathrm{~mL})$. Then the dialysis was conducted at $37{ }^{\circ} \mathrm{C}$ in a shaking culture incubator in dark condition. After timed incubation, $1 \mathrm{ml}$ of dialysate was withdrawn and the platinum content was measured by ICP-OES before the addition of fresh DEPC water solution $(1 \mathrm{~mL})$. The relative percentage of the released platinum from $\mathrm{CNP}_{\mathrm{PtCP} / \mathrm{Cy} 3-\mathrm{si}(\mathrm{c}-\mathrm{fos})}$ was calculated as a function of time.

For si(c-fos) release measurement, the DEPC solutions of $\mathrm{CNP}_{\mathrm{PtCP} / \mathrm{Cy} 3-\mathrm{si}(\mathrm{c}-\mathrm{fos})}$ with or without pre-irradiated $\left(430 \mathrm{~nm}, 20 \mathrm{~mW} / \mathrm{cm}^{3}\right)$ for $30 \mathrm{~min}$ were transferred to an RNase-free centrifuge tube with a filter membrane $(\mathrm{MwCO}=200 \mathrm{KDa})$ and conducted at $37{ }^{\circ} \mathrm{C}$ in a shaking culture incubator in dark condition. At predetermined time points, the tubes were centrifuged at $10000 \mathrm{rpm}$ for $30 \mathrm{~min}$ and the residual $\mathrm{CNP}_{\mathrm{PtCP} / \mathrm{Cy} 3 \text {-si(c-fos) }}$ on the filter membrane were re-dissolved in DEPC water for UV-Vis spectra detection of Cy3-si(c-fos). Then, the relative percentage of si(c-fos) release content was calculated.

\section{Cell culture}

Ovarian cancer cell line A2780 and its platinum-resistant derivative of A2780 ${ }^{\text {DDP }}$ were purchased from institute of biochemistry and cell biology, Chinese Academy of 
Sciences, Shanghai, China. The cells were cultured in a humidified atmosphere containing $5 \% \mathrm{CO}_{2}$ at $37{ }^{\circ} \mathrm{C}$ using RPMI-1640 medium supplemented with $10 \%$ fetal bovine serum, $60 \mathrm{mg} / \mathrm{mL}$ penicillin and $100 \mathrm{mg} / \mathrm{mL}$ streptomycin. Persistent cisplatin screening pressure of $15 \mu \mathrm{M}$ was imposed to the $\mathrm{A} 2780^{\mathrm{DDP}}$ cells during the cultivation.

\section{Cellular uptake of NPPtCP/Cy3-si(c-fos) and $\mathrm{CNP}_{\mathrm{PtCP} / \mathrm{Cy} 3-\mathrm{si}(\mathrm{c}-\mathrm{fos})}$}

The expression level of CD44 receptor in $\mathrm{A} 2780^{\mathrm{DDP}}$ cells was first determined by flow cytometry as previously described. ${ }^{3}$ Briefly, FITC-conjugated anti-CD44 antibody or IgG 2a isotype control was incubated with $\mathrm{A} 2780^{\mathrm{DDP}}$ cells on ice for 30 min. Thereafter, cells were washed with PBS and analyzed by flow cytometry.

In the cellular uptake analysis, A2780 ${ }^{\mathrm{DDP}}$ cells were seeded in 6-well plates at a density of $2.5 \times 10^{5}$ cells per well in $2 \mathrm{~mL}$ medium and incubated overnight. The medium was then replaced with $2 \mathrm{~mL}$ of fresh medium without serum. The solutions $(250 \mu \mathrm{L})$ of $\mathrm{NP}_{\mathrm{PtCP} / \mathrm{Cy} 3-\mathrm{si}(\mathrm{c}-\mathrm{fos})}$ and $\mathrm{CNP}_{\mathrm{PtCP} / \mathrm{Cy} 3-\mathrm{si}(\mathrm{c}-\mathrm{fos})}(\mathrm{Pt}: 10.8 \mu \mathrm{M}$ and $\mathrm{Cy} 3$-si(c-fos): $1.25 \mu \mathrm{g}$ ) were added and incubated for $0.5 \mathrm{~h}, 2 \mathrm{~h}$ and $4 \mathrm{~h}$. In the competitive assay, the cells were pre-incubated with $10 \mathrm{mg} / \mathrm{mL}$ of free HA for $1 \mathrm{~h}$ to block the CD44 receptor. Prior to observation with CLSM, the cells were washed with cold PBS for three times, fixed with $4 \%$ paraformaldehyde for $15 \mathrm{~min}$ at room temperature, and then the nuclei were stained with Hoechst 33258 for another 8 min. Finally, the cells were washed three times with cold PBS and observed by CLSM. For flow cytometry analysis, the medium was removed and the cells were rinsed with PBS, harvested by trypsin treatment. After two cycles of washing and centrifuging at $1,000 \mathrm{rpm}$ for 5 
min at $4{ }^{\circ} \mathrm{C}$, the cells were re-suspended in $100 \mu \mathrm{L}$ PBS, and analyzed immediately using flow cytometry.

\section{Endo/lysosomal damage induced by $\mathrm{N}_{3}{ }^{\circ}$}

$\mathrm{A} 2780^{\mathrm{DDP}}$ cells were seeded in 6 -well plates at a density of $2.5 \times 10^{5}$ cells per well in $2 \mathrm{~mL}$ medium and incubated overnight. The medium was replaced with $2 \mathrm{~mL}$ of fresh medium without serum. Following incubation with $\mathrm{CNP}_{\mathrm{PtCP} / \mathrm{si}(\mathrm{c}-\mathrm{fos})}(\mathrm{Pt}: 10.8 \mu \mathrm{M}$, si(c-fos): $0.625 \mu \mathrm{g} / \mathrm{mL}$ ) for $4 \mathrm{~h}$, the medium was refreshed and the cells were treated with or without irradiation for different time intervals. Then the cells were stained with AO (100 $\mu \mathrm{g} / \mathrm{mL})$ for $10 \mathrm{~min}$ and washed three times with PBS before imaged by BioTek Cytation ${ }^{\mathrm{TM}} 5$.

\section{Light-controlled intercellular endo/lysosomal escape and si(c-fos) unpacking}

The light-controlled si(c-fos) endo/lysosomal escape and unpacking were visualized by CLSM. For si(c-fos) endo/lysosomal escape experiment, A2780 ${ }^{\text {DDP }}$ cells were seeded onto $12 \mathrm{~mm}$ coverslips in 24 -well plates at a density of $5 \times 10^{4}$ cells per well in $0.5 \mathrm{~mL}$ medium and incubated overnight. The medium was then replaced with RPMI 1640 medium without serum. The solution $(250 \mu \mathrm{L})$ of medium containing $\mathrm{CNP}_{\text {PtCP/FAM-si(c-fos) }}(\mathrm{FAM}$-si(c-fos): $0.25 \mu \mathrm{g}$ ) was added into each well. Then the cells were divided into two groups. After incubated for determined time intervals $(0.5,2,4$ 6 and $12 \mathrm{~h}$ ), the medium was replaced with fresh medium. For one group, the cells were incubated in the dark. The cells of the other group were irradiated with visible light for 10 or 20 min after $0.5,2$ or 4 h incubation. Thereafter, Lyso-Tracker Red probe was used to stain endo/lysosomes and the nuclei were stained by Hoechst 
33258. Finally, the cells were washed three times with cold PBS, and fixed with $4 \%$ paraformaldehyde for $15 \mathrm{~min}$ at room temperature before imaged on a CLSM.

For si(c-fos) unpacking study, A2780 ${ }^{\mathrm{DDP}}$ cells were incubated with $\mathrm{CNP}_{\text {RhB-PtCP/FAM-si(c-fos) }}($ FAM-si(c-fos): $0.25 \mu \mathrm{g}$ ) for 4,6 or $12 \mathrm{~h}$. The cells were treated with or without irradiation for predetermined time intervals $(0,10$ and $20 \mathrm{~min})$ after the $4 \mathrm{~h}$ incubation. The other groups $(6$, or $12 \mathrm{~h})$ were always maintained in the dark. Then, the cell nuclei were stained using Hoechst 33258, and the cells were washed three times with cold PBS, fixed with $4 \%$ paraformaldehyde and finally visualized by CLSM.

\section{Cytotoxicity assay}

Cytotoxicity was assessed using a standard MTT assay.

For verify the safety of azidyl radicals, L929 cells incubated with Pt(IV), $\mathrm{CNP}_{\mathrm{PtCP} / \mathrm{siNC}}$ and $\mathrm{CNP}_{\mathrm{PtCP} / \mathrm{si}(\mathrm{c}-\mathrm{fos})}(\mathrm{Pt}$ concentration from 1.56 to $100 \mu \mathrm{M}$ ) for $4 \mathrm{~h}$ before irradiated for $20 \mathrm{~min}$, and then the cell viability was tested according to the standard MTT protocol after further incubation for 2 or $4 \mathrm{~h}$. L929 cells incubated with Pt(IV), $\mathrm{CNP}_{\mathrm{PtCP} / \text { sinC }}$ and $\mathrm{CNP}_{\mathrm{PtCP} / \mathrm{si}(\mathrm{c}-\text { fos })}(\mathrm{Pt}$ concentration was $50 \mu \mathrm{M})$ for $4 \mathrm{~h}$ before irradiated for $20 \mathrm{~min}$. Then cells were divided into two groups, one group of cells were co-stained with calcein AM and propidium iodide (PI), and the other group of cells were used for comet assay after further incubation for $4 \mathrm{~h}$.

The in vitro anti-cancer efficacy of $\mathrm{CNP}_{\mathrm{PtCP} / \mathrm{si}(\mathrm{c}-\mathrm{fos})}$ was then performed on $\mathrm{A} 2780$ and $\mathrm{A} 2780^{\mathrm{DDP}}$ cells. The cells were seeded in 96-well plates at an intensity of 5000 cells per well and incubated for $24 \mathrm{~h}$. The medium was then replaced with fresh 
medium without serum and then cisplatin, $\mathrm{Pt}(\mathrm{IV}), \mathrm{CNP}_{\mathrm{PtCP} / \mathrm{siNC}}$ and $\mathrm{CNP}_{\mathrm{PtCP} / \mathrm{si}(\mathrm{c}-\mathrm{fos})}$ with a final Pt concentration from 1.56 to $100 \mu \mathrm{M}$ (si(c-fos) concentration from 90.62 to $5800 \mu \mathrm{g} / \mathrm{L}$ ) were applied to cells. After $4 \mathrm{~h}$ incubation, the medium was changed back to fresh medium with $10 \%$ FBS and the cells were treated with or without irradiation. For irradiation group, the cells were irradiated for $20 \mathrm{~min}$, and then all groups were continuously incubated for another $48 \mathrm{~h}$ or $72 \mathrm{~h}$. Then $20 \mathrm{~mL}$ of MTT solution $(20 \mu \mathrm{L}, 5 \mathrm{mg} / \mathrm{mL})$ was added and the cells were further incubated for another $4 \mathrm{~h}$, allowing viable cells to change the yellow tetrazolium salt into dark blue formazan crystals. The culture medium was replaced by $150 \mu \mathrm{L}$ DMSO to dissolve the formed formazan crystals and the absorbance of the formazan product was detected at $490 \mathrm{~nm}$ using a microplate reader.

The phototoxicity of the $430 \mathrm{~nm}$ light was also investigated against A2780 and $\mathrm{A} 2780^{\mathrm{DDP}}$ cells. The seeded cells were irradiated for 10, 20, 30 and $60 \mathrm{~min}$ and further incubated to $48 \mathrm{~h}$, MTT assay was used to evaluate the phototoxicity of the light.

Combination index analysis of $\mathrm{Pt}$ and si(c-fos)

Combination index (CI) was calculated with the equation as below:

$$
\mathrm{CI}=\frac{\mathrm{Ca}, \mathrm{x}}{\mathrm{ICx}, \mathrm{a}}+\frac{\mathrm{Cb}, \mathrm{x}}{\mathrm{ICx}, \mathrm{b}}
$$

$\mathrm{C}_{\mathrm{a}, \mathrm{x}}$ and $\mathrm{C}_{\mathrm{b}, \mathrm{x}}$ are the concentrations of drug $\mathrm{A}(\mathrm{Pt})$ and drug $\mathrm{B}(\mathrm{si}(\mathrm{c}-\mathrm{fos}))$ used in combination to achieve $\mathrm{x} \%$ drug effect under irradiation. $\mathrm{IC}_{\mathrm{x}, \mathrm{a}}$ and $\mathrm{IC}_{\mathrm{x}, \mathrm{b}}$ are the concentrations for $\mathrm{CNP}_{\mathrm{PtCP} / \mathrm{si} \text { (c-fos) }}$ under irradiation and in dark condition to achieve the same effect, respectively. The CI values lower than, equal to, and higher than 1 denote synergism, additivity, and antagonism, respectively. 


\section{Cell apoptosis}

A2780 and $\mathrm{A} 2780^{\mathrm{DDP}}$ cells were seeded in 6-well plates at a density of $2.5 \times 10^{5}$ cells per well and incubated overnight. The medium was replaced with fresh medium containing cisplatin $(10.8 \mu \mathrm{M}), \mathrm{Pt}(\mathrm{IV})(10.8 \mu \mathrm{M}), \mathrm{CNP}_{\mathrm{PtCP} / \mathrm{siNC}}(\mathrm{Pt}: 10.8 \mu \mathrm{M}$, siNC: $0.625 \mu \mathrm{g} / \mathrm{mL})$ or $\mathrm{CNP}_{\mathrm{PtCP} / \mathrm{si} \text { (c-fos) }}(\mathrm{Pt}: 10.8 \mu \mathrm{M}$, si(c-fos): $0.625 \mu \mathrm{g} / \mathrm{mL})$ and incubated for $4 \mathrm{~h}$. Then the medium was replaced with fresh medium and treated with or without irradiation. For irradiation group, the cells were irradiated for $20 \mathrm{~min}$ and the cells were incubated for another $20 \mathrm{~h}$. The cells of the other group were incubated to $24 \mathrm{~h}$ in dark condition. After that, the cells were harvested by trypsin treatment and collected by centrifugation and suspended in binding buffer. Finally, the cells were stained by annexin V/PI apoptosis detection kit according to the manufacturer's protocol for flow cytometry detection.

\section{Western blotting assay}

A 2780 or $\mathrm{A} 2780^{\mathrm{DDP}}$ cells were seeded into 6-well plates at a density of $2.5 \times 10^{5}$ cells per well in $2 \mathrm{~mL}$ medium and incubated overnight to reach confluence. The medium was replaced with fresh medium without serum and different drugs (PBS, cisplatin $(10.8 \mu \mathrm{M}), \mathrm{Pt}(\mathrm{IV})(10.8 \mu \mathrm{M}), \mathrm{CNP}_{\mathrm{PtCP} / \mathrm{siNC}}(\mathrm{Pt}: 10.8 \mu \mathrm{M}$, siNC: $0.625 \mu \mathrm{g} / \mathrm{mL})$ and $\mathrm{CNP}_{\mathrm{PtCP} / \mathrm{si}(\mathrm{c}-\mathrm{fos})}(\mathrm{Pt}: 10.8 \mu \mathrm{M}$, si(c-fos): $\left.0.625 \mu \mathrm{g} / \mathrm{mL})\right)$ were applied to cells. After $4 \mathrm{~h}$ incubation, the medium was replaced with fresh medium with $10 \% \mathrm{FBS}$, and the cells were divided into two groups. For one group, the cells were further incubated to $48 \mathrm{~h}$ in dark condition. For the other group, the cells were irradiated for $20 \mathrm{~min}$ and incubated to $48 \mathrm{~h}$ as well. Then the cells of both groups were lysed in $100 \mu \mathrm{L}$ lysis 
buffer and the total protein content was detected using BCA protein assay. The protein samples were added with loading buffer and incubated for 15 min at $95{ }^{\circ} \mathrm{C}$, and then $40 \mu \mathrm{g}$ of proteins were separated on a $12 \%$ SDS-polyacrylamide gels electrophoresis, followed by electrotransfering to a polyvinylidene fluoride (PVDF) membrane. The membrane was incubated firstly with $5 \%$ nonfat milk powder in tris buffered saline with Tween-20 (TBST) to block the nonspecific binding sites and then incubated with primary antibodies for $2 \mathrm{~h}$. Then, the membrane was rinsed in TBST and incubated with horseradish peroxidase labeled secondary antibodies at the dilution of 1:1000 for 1.5 h. Finally, the protein bands were detected with ECL detection system. The expression levels of proteins were normalized to $\beta$-actin protein.

\section{Cellular uptake of Pt}

$\mathrm{A} 2780$ or $\mathrm{A} 2780^{\mathrm{DDP}}$ cells were seeded in 6-well plates at a density of $2.5 \times 10^{5}$ cells per well and incubated for $24 \mathrm{~h}$, respectively. The cells were treated with cisplatin, $\mathrm{Pt}(\mathrm{IV}), \mathrm{CNP}_{\mathrm{PtCP} / \mathrm{siNC}}$ or $\mathrm{CNP}_{\mathrm{PtCP} / \mathrm{si} \text { (c-fos) }}$ with a final Pt concentration of $10.8 \mu \mathrm{M}$ for $4 \mathrm{~h}$ at $37{ }^{\circ} \mathrm{C}$ in the absence or presence of light irradiation. For determination of cellular platinum uptake, the cells were washed with PBS three times and then digested. After counting, the cells were lysed by lysis buffer and the bioactive platinum content in the cell lysis samples was determined using ICP-MS. In order to evaluate the platinum content adducted to DNA, the cells were washed with PBS three times and replaced with fresh medium for another $24 \mathrm{~h}$, and then the DNA in the cells was isolated according to DNA determination reagent kit. After DNA determination, the platinum content was determined using ICP-MS 


\section{Establishment of tumor model}

Female nude BALB/c mice (4 - 5 weeks old, 16 - 20 g) were bought from Beijing Huafukang Biological Technology Co., Ltd. Animal studies were approved by Ethical Committee of Changchun Institute of Applied Chemistry, Chinese Academy of Sciences. All the mice were maintained at required conditions and had free access to food and water throughout the experiments.

To evaluate the tumor inhibition ability of $\mathrm{CNP}_{\mathrm{PtCP} / \mathrm{si}(\mathrm{c} \text {-fos) }}$ in vivo, female nude BALB/c mice bearing A2780 ${ }^{\mathrm{DDP}}$ xenograft model (7 - 8 weeks old) were established. In details, $4 \times 10^{6} \mathrm{~A} 2780^{\mathrm{DDP}}$ cells were inoculated subcutaneously into the right flank of nude mice. After 3 weeks, the tumor nodules were grown to a volume about 100 $\mathrm{mm}^{3}$ for further use.

\section{Biodistribution of platinum in mice}

The tumor-bearing nude mice were randomly divided into cisplatin $(2.77 \mathrm{mg} \mathrm{Pt} / \mathrm{kg}$, without irradiation) $(\mathrm{n}=9), \mathrm{NP}_{\mathrm{PtCP} / \mathrm{si}(\mathrm{c}-\text {-fos })}(2.77 \mathrm{mg} \mathrm{Pt} / \mathrm{kg}$, without irradiation $)(\mathrm{n}=9)$ and $\mathrm{CNP}_{\mathrm{PtCP} / \mathrm{si}(\mathrm{c}-\text { fos })}(2.77 \mathrm{mg} \mathrm{Pt} / \mathrm{kg}$, without irradiation $)(\mathrm{n}=9)$ groups. After once intravenous injection, the mice were sacrificed at different time points $(1 \mathrm{~h}, 12 \mathrm{~h}$ and 24 h). Major tissues of heart, liver, spleen, lung, kidney and tumor were collected and weighted. To investigate whether the platinum accumulation can influenced by light treatment, tumor-bearing mice were irradiated for $30 \mathrm{~min}$ at the tumor site after intravenous injection with $\mathrm{CNP}_{\mathrm{PtCP} / \mathrm{si}(\mathrm{c}-\text { fos })}(2.77 \mathrm{mg} \mathrm{Pt} / \mathrm{kg})(\mathrm{n}=6)$ for $1 \mathrm{~h}$, and then the mice were sacrificed at different time points $(12 \mathrm{~h}$ or $24 \mathrm{~h})$. All the tissues were added with $\mathrm{HNO}_{3}$ and $\mathrm{H}_{2} \mathrm{O}_{2}$ and heated to obtain clear solutions. The platinum concentration 
of the solutions was measured by ICP-MS and the content in each tissue was calculated.

\section{In vivo tumor inhibition assay}

After the tumor-bearing nude mice were divided into six groups randomly ( $\mathrm{n}=5$ per group), the initial weight and tumor volume were measured and recorded. Next, the mice were treated with saline (without irradiation), Cispatin $(2.77 \mathrm{mg} \mathrm{Pt} / \mathrm{kg}$, without irradiation), $\mathrm{CNP}_{\mathrm{PtCP} / \mathrm{siNC}}(2.77 \mathrm{mg} \mathrm{Pt} / \mathrm{kg}, 825 \mu \mathrm{g} \quad \mathrm{siNC} / \mathrm{kg}$, without irradiation), $\mathrm{CNP}_{\mathrm{PtCP} / \mathrm{sinC}}(2.77 \mathrm{mg} \mathrm{Pt} / \mathrm{kg}, 825 \mu \mathrm{g}$ siNC/kg, with irradiation), $\mathrm{CNP}_{\mathrm{PtCP} / \mathrm{si}(\mathrm{c}-\mathrm{fos})}(2.77 \mathrm{mg} \mathrm{Pt} / \mathrm{kg}, 825 \mu \mathrm{g} \quad \mathrm{si}(\mathrm{c}-\mathrm{fos}) / \mathrm{kg}$, without irradiation) or $\mathrm{CNP}_{\mathrm{PtCP} / \mathrm{si} \text { (c-fos) }}(2.77 \mathrm{mg} \mathrm{Pt} / \mathrm{kg}, 825 \mu \mathrm{g}$ si(c-fos)/kg, with irradiation) via tail vein injection at day 0 , day 3 and day 6 . For irradiation groups, after $12 \mathrm{~h}$ intravenous injection each time, the mice were irradiated with visible light for $30 \mathrm{~min}$ at the tumor site, while the other groups were maintained in the dark all the time. The body weight and tumor volume of each mouse were measured every three days, and the tumor volume was calculated using the following equation: tumor volume $=$ length $\times$ width $\times$ width $/ 2$.

At the end of the test, the mice from each group were sacrificed and the tumor were excised and collected for further analysis.

In vivo oxidizing radical generation induced by $\mathrm{N}_{3}{ }^{\cdot}$ and the intracellular endo/lysosomes damage of tumor tissue

$\mathrm{BALB} / \mathrm{c}$ mice bearing $\mathrm{A} 2780^{\mathrm{DDP}}$ xenograft model at $100 \mathrm{~mm}^{3}$ were intravenous injected with $\mathrm{CNP}_{\mathrm{PtCP} / \mathrm{si}(\mathrm{c}-\mathrm{fos})}(2.77 \mathrm{mg} \mathrm{Pt} / \mathrm{kg})(\mathrm{n}=3)$ and saline as control. After $12 \mathrm{~h}$ 
injection, the mice were irradiated with or without visible light for $30 \mathrm{~min}$ at the tumor site. The tumors were peeled from the sacrificed mice and immersed into the Krebs-Ringer buffer, and then cut into pieces and shaken to get monodispersed cells. The tumor cells were filtrate through nylon mesh and then centrifuged at $1000 \mathrm{rpm}$ for 5 min. After washed with Krebs-Ringer buffer, the cells were stained with DCF-DA $(20 \mu \mathrm{M})$ in fresh serum-free culture medium. Then the tumor intracellular oxidizing radical level was analyzed immediately using flow cytometry imaging system (Amnis). ${ }^{4}$

To observe the tumor intracellular endo/lysosomes damage, the tumor tissues separated from the sacrificed mice were fixed in glutaraldehyde (4\%), embedded in resin, cut to ultrathin sections, stained by osmic acid, uranyl acetate and lead citrate, finally visualized using a Hitachi H-7650 TEM (Japan). ${ }^{5}$

\section{Histological and immunohistochemical analyses}

At the end of tumor inhibition study, the tumors and major organs (heart, liver, spleen, lung and kidney) were collected and fixed with $4 \%$ neutral buffered paraformaldehyde, embedded in paraffin, and then the tissues were cut into slices at 2 $\mu \mathrm{m}$ thick using microtome YD-1508A and mounted onto glass slides.

For histological analysis, all the tissues were stained with $H \& E$ and visualized by BioTek Cytation ${ }^{\mathrm{TM}} 5$.

For immunohistochemical analysis, the tumor sections were incubated with $1 \%$ BSA in phosphate buffered saline tween-20 (PBST) for 30 min to block unspecific binding of antibodies, and incubated with antibody c-fos and $\gamma \mathrm{H} 2 \mathrm{AX}$ (1: 500 diluted 
in $1 \%$ BSA in PBST) for $2 \mathrm{~h}$ at $37^{\circ} \mathrm{C}$ in a humidified chamber, respectively, followed by incubation with the corresponding secondary antibody for $1 \mathrm{~h}$ at $37{ }^{\circ} \mathrm{C}$ in dark condition. Finally, samples were visualized under a CLSM system.

\section{TUNEL assay}

The aforementioned sliced tumor tissue sections were used for in situ nick-end labelling of nuclear DNA fragmentation with a TUNEL apoptosis detection kit according to the supplier's instructions and analyzed by CLSM.

\section{Statistical analysis}

Data were presented as mean \pm standard deviation (SD). The statistical significance was carried out by two-tailed Student's t-test and significant differences between groups were indicated by $* \mathrm{p}<0.05, * * \mathrm{p}<0.01, * * * \mathrm{p}<0.001$, respectively.

\section{References}

(1) Mackay, F. S.; Woods, J. A.; Heringová, P.; Kašpárková, J.; Pizarro, A. M.; Moggach, S. A.; Parsons, S.; Brabec, V.; Sadler, P. J. A potent cytotoxic photoactivated platinum complex. Proc. Natl. Acad. Sci. USA 2007, 104, 2074320748.

(2) Yin, Q.; Gao, Y.; Zhang, Z. W.; Zhang, P. C.; Li, Y. P. Bioreducible poly ( $\beta$-amino esters)/shRNA complex nanoparticles for efficient RNA delivery. $J$. Control. Release 2011, 151, 35-44.

(3) Cohen, Z. R.; Ramishetti, S.; Peshes-Yaloz, N.; Goldsmith, M.; Wohl, A.; Zibly, Z.; Peer, D. Localized RNAi therapeutics of chemoresistant grade IV glioma using hyaluronan-grafted lipid-based nanoparticles. ACS Nano 2015, 9, $1581-1591$. 
(4) Ma, P. a.; Xiao, H.; Yu, C.; Liu, J.; Cheng, Z.; Song, H.; Zhang, X.; Li, C.; Wang, J.; Gu, Z. Enhanced cisplatin chemotherapy by iron oxide nanocarrier-mediated generation of highly toxic reactive oxygen species. Nano Lett. 2017, 17, 928-937.

(5) Ma, P. a.; Xiao, H.; Li, X.; Li, C.; Dai, Y.; Cheng, Z.; Jing, X.; Lin, J. Rational design of multifunctional upconversion nanocrystals/polymer nanocomposites for cisplatin (IV) delivery and biomedical imaging. Adv. Mater. 2013, 25, 4898-4905. 
A

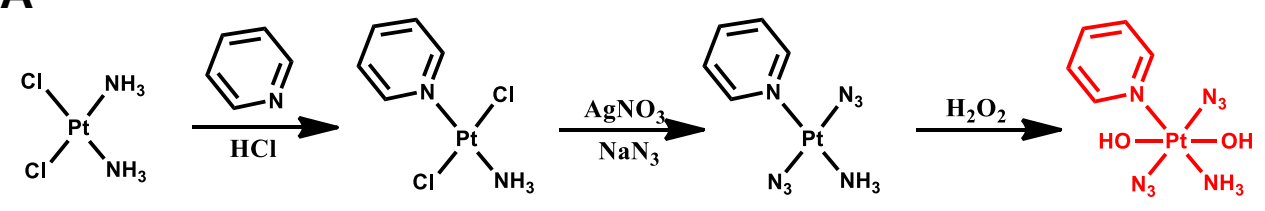

Cisplatin

Pt(IV)

B

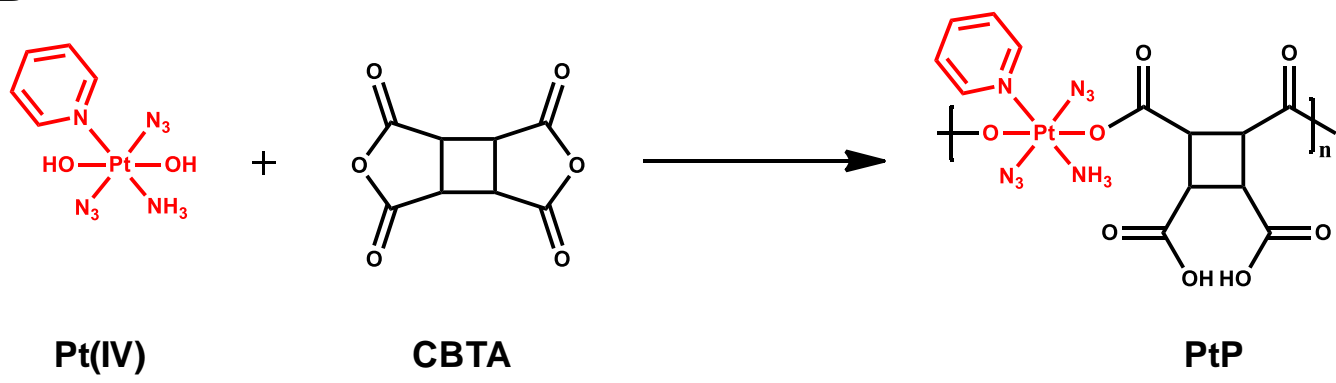

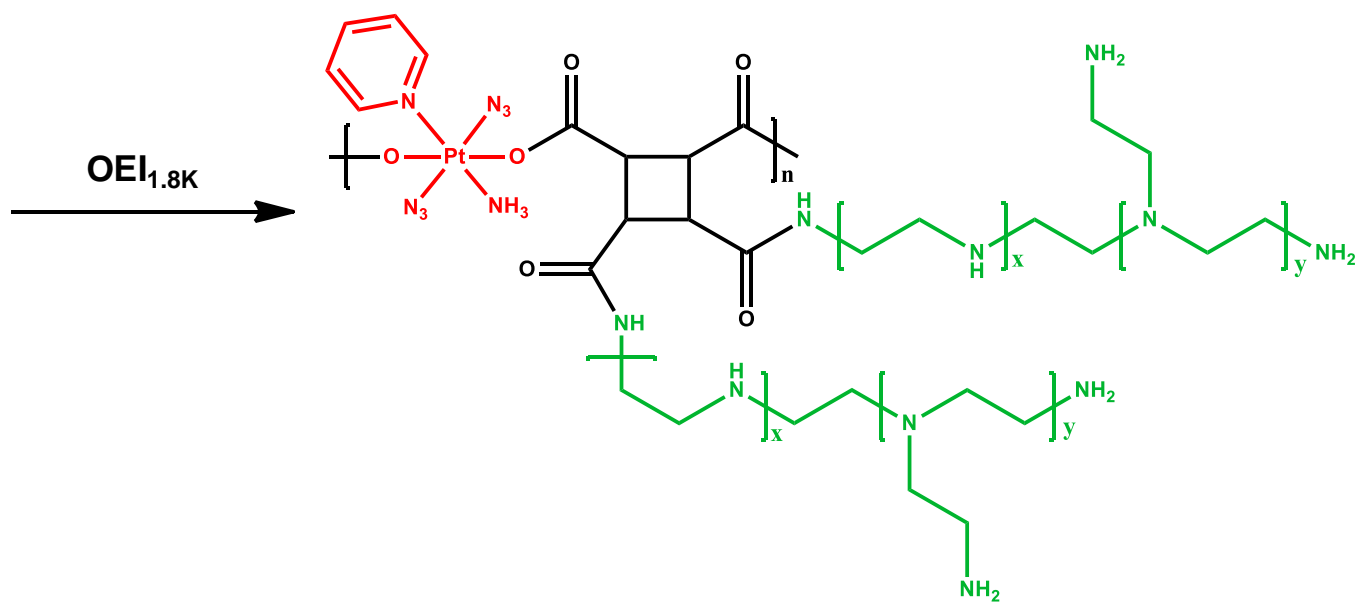

PtCP

Scheme S1. Synthesis routs and chemical structures of (A) Pt(IV) and (B) PtCP. 
A

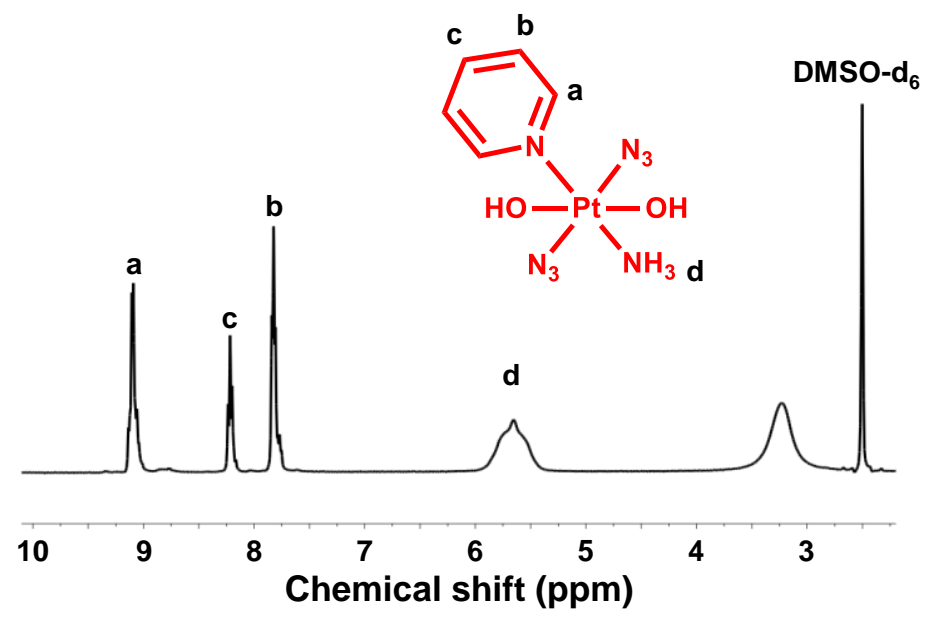

B

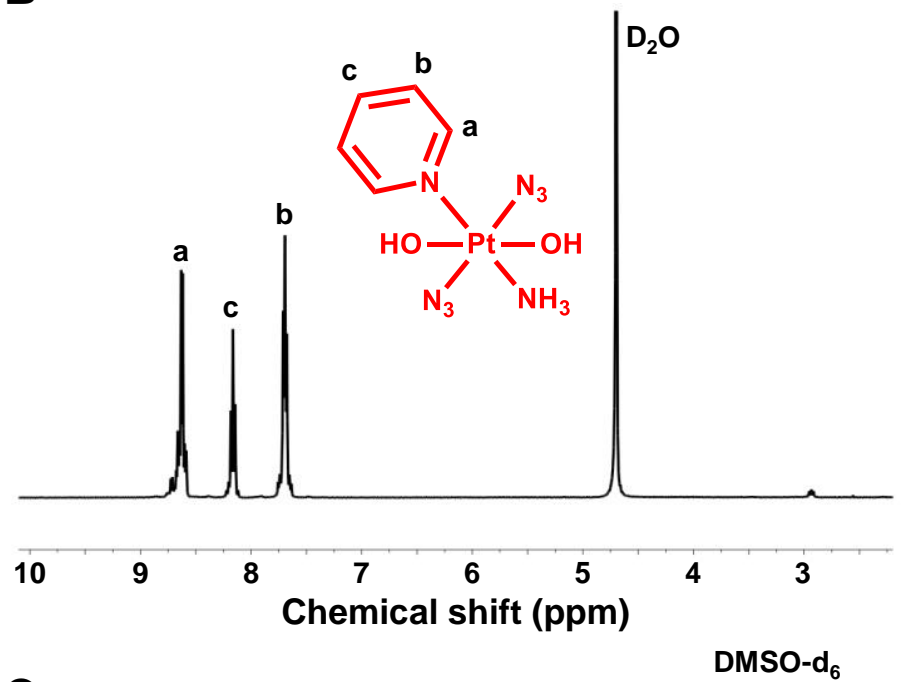

C
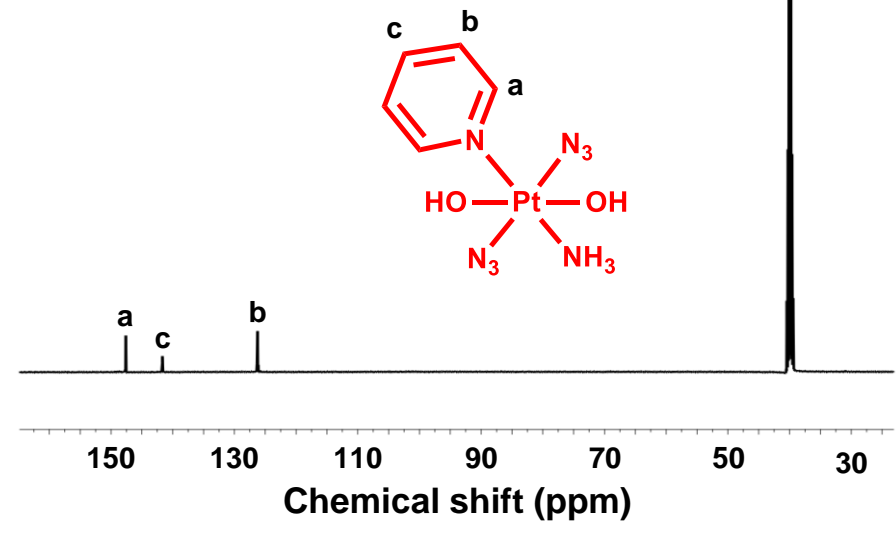

Figure S1. Characterization of Pt(IV) by NMR. (A) ${ }^{1} \mathrm{H}$ NMR spectra in $\mathrm{d}^{6}$-DMSO. (B) ${ }^{1} \mathrm{H}$ NMR spectra in $\mathrm{D}_{2} \mathrm{O}$. (C) ${ }^{13} \mathrm{C}$ NMR spectra in $\mathrm{d}^{6}$-DMSO. 


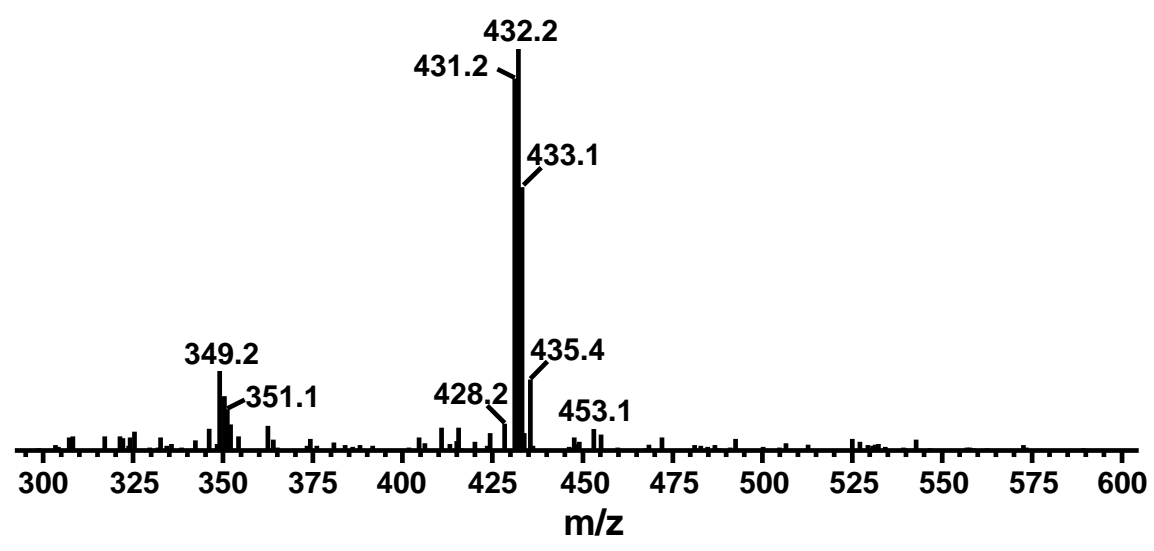

Figure S2. Characterization of Pt(IV) by ESI-MS. 


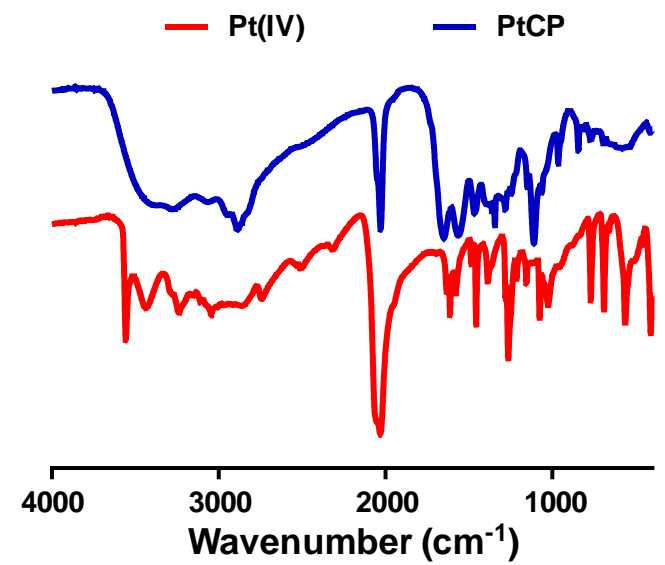

Figure S3. FT-IR spectra of Pt(IV) and PtCP. 


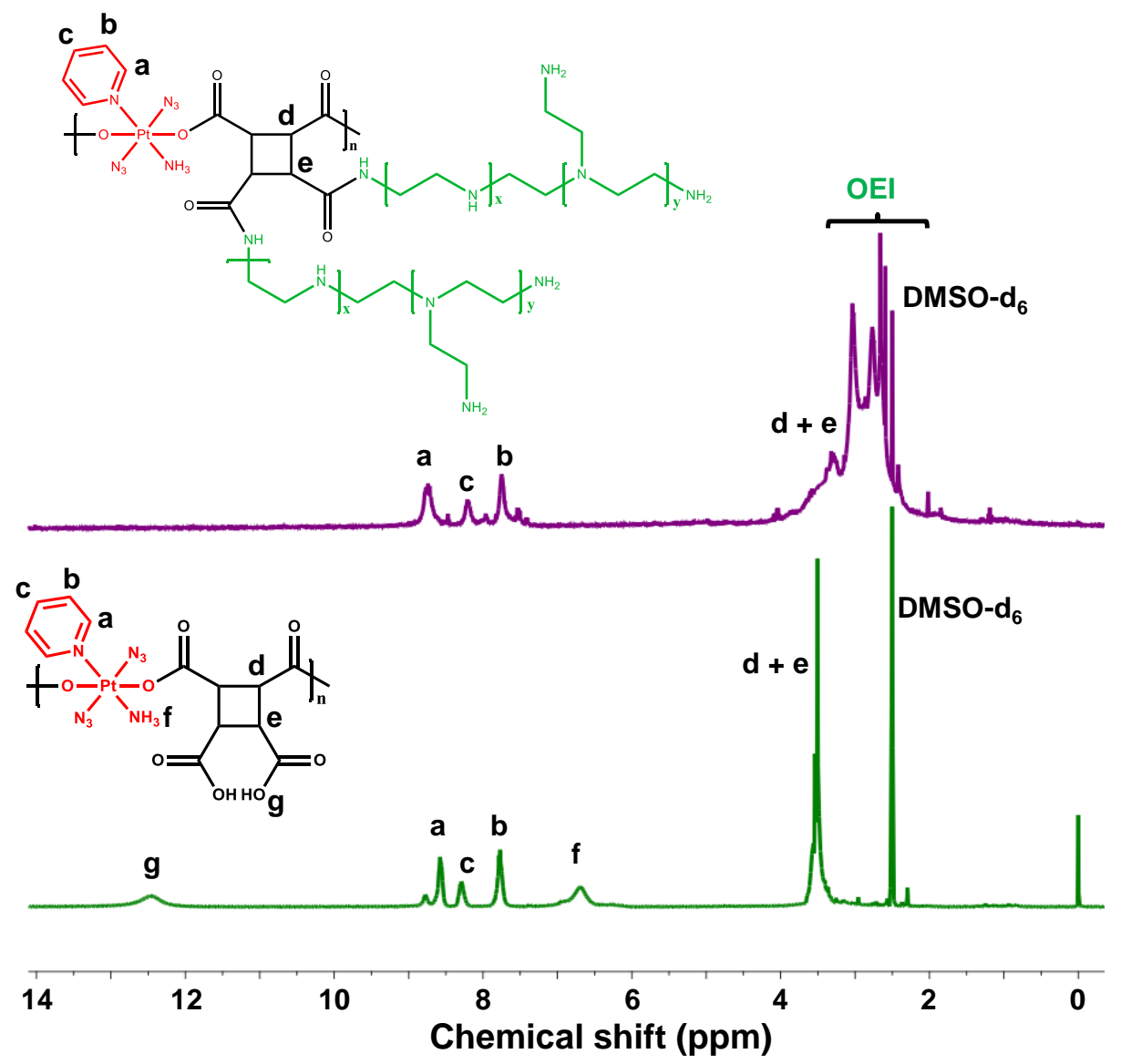

Figure S4. Characterization of PtP and PtCP by ${ }^{1} \mathrm{H}$ NMR spectra in $\mathrm{d}^{6}$-DMSO. 


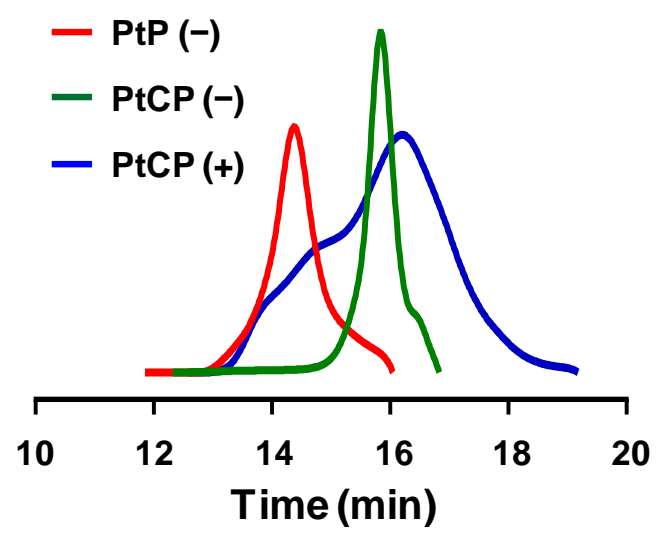

Figure S5. GPC curves of PtP and PtCP. "-" indicates in the dark, "+" indicates with irradiation. Light source: $430 \mathrm{~nm}, 20 \mathrm{~mW} / \mathrm{cm}^{2}, 60 \mathrm{~min}$. 

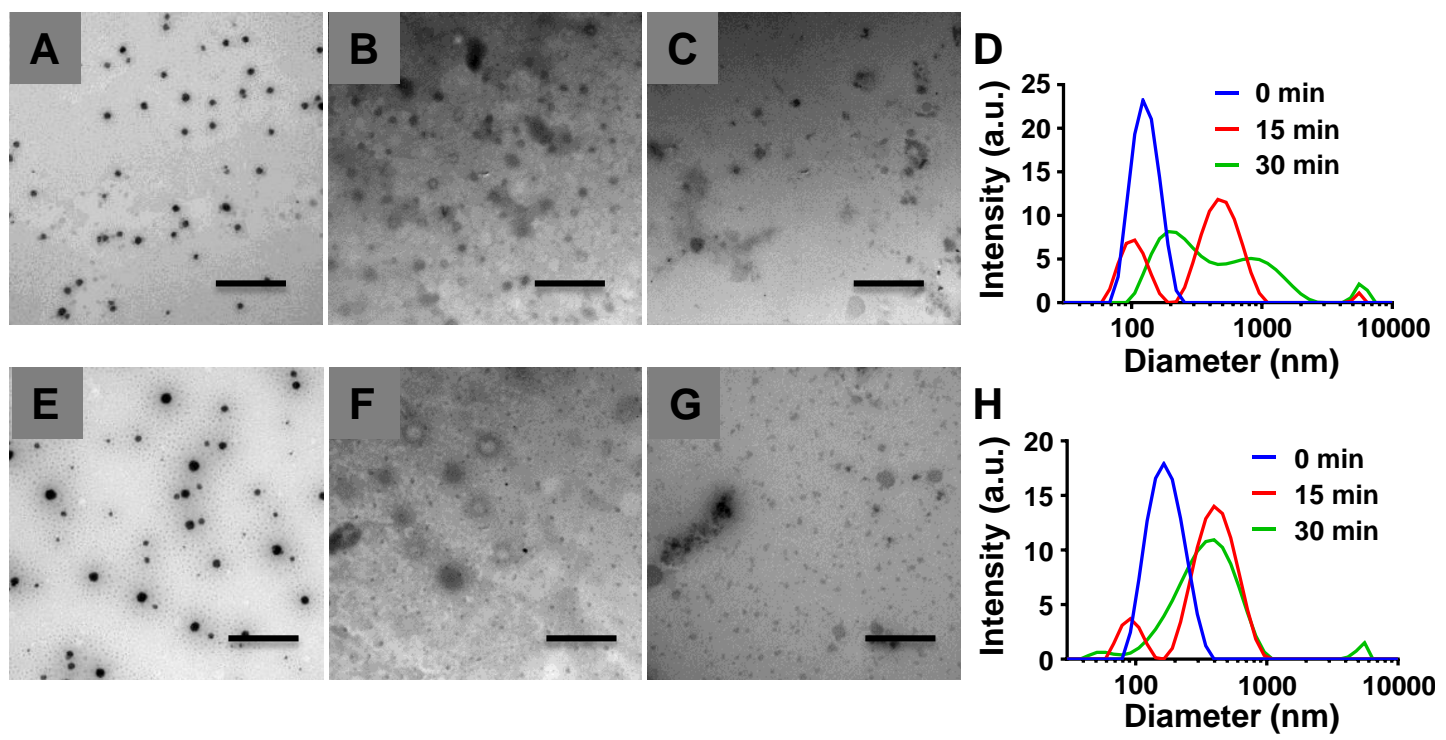

Figure S6. TEM images of $\mathrm{NP}_{\mathrm{PtCP}}$ after irradiation for indicated time intervals: 0 min (A), $15 \mathrm{~min}(\mathrm{~B})$ and $30 \mathrm{~min}(\mathrm{C})$. (D) The corresponding size distribution of $\mathrm{NP}_{\mathrm{PtCP}}$ after light irradiation. TEM images of $\mathrm{NP}_{\mathrm{PtCP} / \mathrm{si}(\mathrm{c}-\mathrm{fos})}$ after irradiation for indicated time intervals: $0 \mathrm{~min}(\mathrm{E}), 15 \mathrm{~min}(\mathrm{~F})$ and $30 \mathrm{~min}(\mathrm{G})$. (H) The corresponding size distribution of $\mathrm{NP}_{\mathrm{PtCP} / \mathrm{si}(\mathrm{c}-\mathrm{fos})}$ after light irradiation. Light source: $430 \mathrm{~nm}, 20 \mathrm{~mW} / \mathrm{cm}^{2}$. Scale bar $=500 \mathrm{~nm}$. 


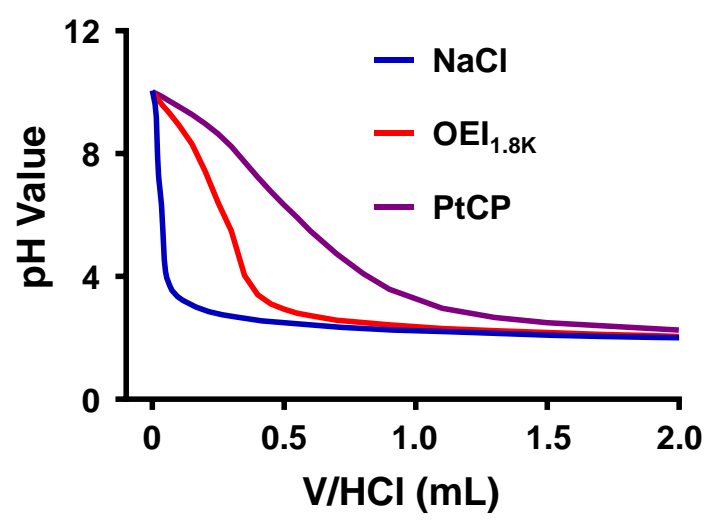

Figure S7. The buffering capacity of PtCP by titration of PtCP in $150 \mathrm{mM} \mathrm{NaCl}$ solution with $0.1 \mathrm{M} \mathrm{HCl}$. 
A

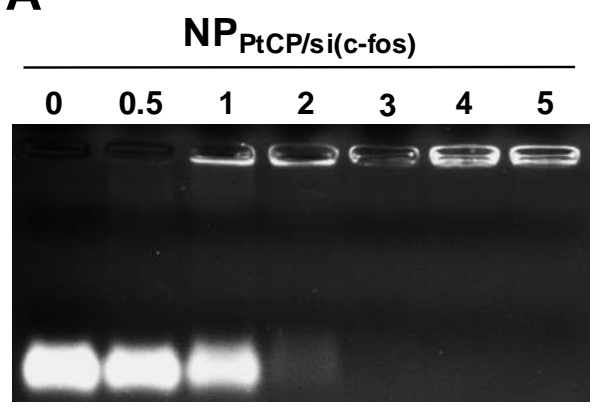

B

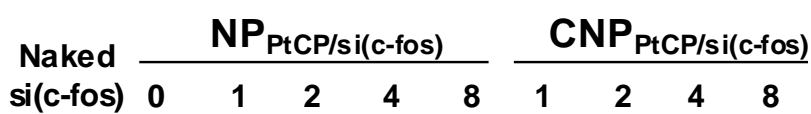

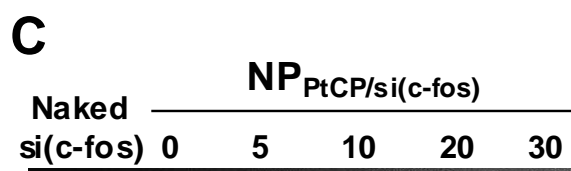

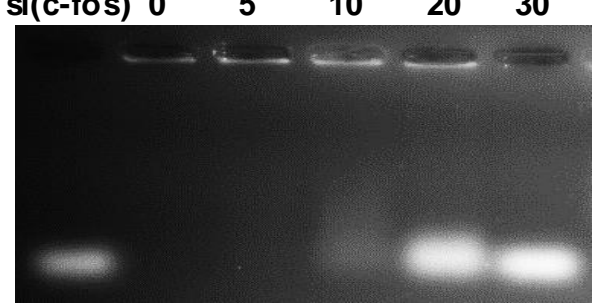

D

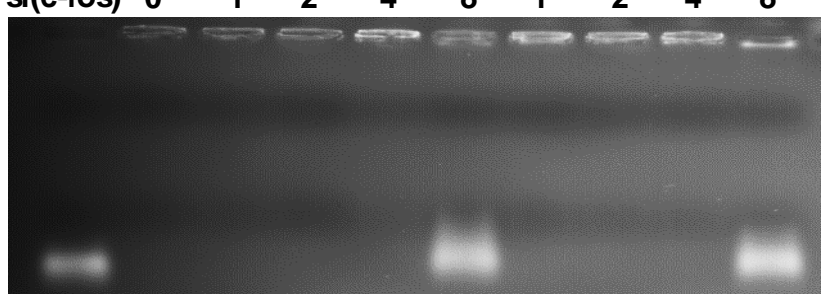

Figure S8. (A) Gel retardation assay of $\mathrm{NP}_{\mathrm{PtCP} / \mathrm{si}(\mathrm{c}-\text {-fos })}$ at various weight ratios of $\mathrm{PtCP}$ to si(c-fos). (B) Anti-anion displacement assay of $\mathrm{NP}_{\mathrm{PtCP} / \mathrm{si}(\mathrm{c}-\text { fos })}$ and $\mathrm{CNP}_{\mathrm{PtCP} / \mathrm{si}(\mathrm{c}-\mathrm{fos})}$ at various weight ratios of sodium heparin to si(c-fos). Photoresponsive dissociation of $\mathrm{NP}_{\mathrm{PtCP} / \mathrm{si}(\mathrm{c}-\mathrm{fos})}$ and $\mathrm{CNP}_{\mathrm{PtCP} / \mathrm{si}(\mathrm{c}-\mathrm{fos})}$. (C) $\mathrm{NP}_{\mathrm{PtCP} / \mathrm{si}(\mathrm{c}-\text { fos })}$ were preirradiated for different time intervals $(0,5,10,20$ and $30 \mathrm{~min})$ and analyzed by gel retardation assay; (D) $\mathrm{NP}_{\mathrm{PtCP} / \mathrm{si}(\mathrm{c} \text {-fos) }}$ and $\mathrm{CNP}_{\mathrm{PtCP} / \mathrm{si}(\mathrm{c}-\mathrm{fos})}$ were pre-irradiated for $10 \mathrm{~min}$, then incubated with various weight ratios of sodium heparin to si(c-fos) and analyzed by gel retardation assay. Light source: $430 \mathrm{~nm}, 20 \mathrm{~mW} / \mathrm{cm}^{2}$. 


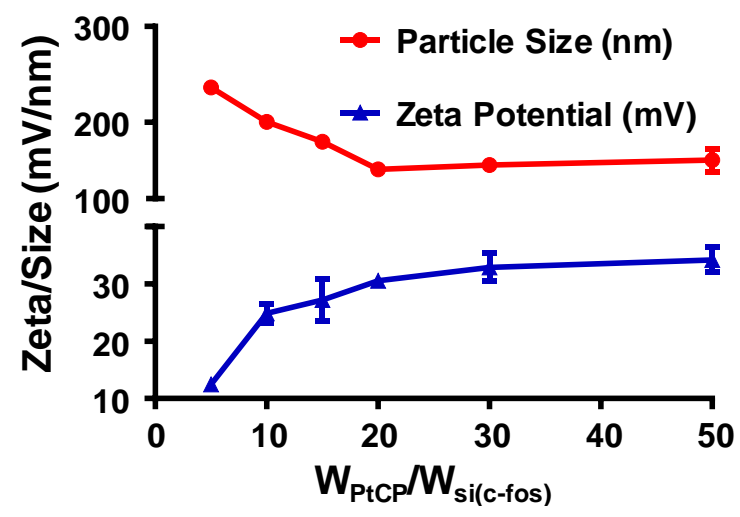

Figure S9. Diameter and zeta potential changes of $\mathrm{NP}_{\mathrm{PtCP} / \mathrm{si}(\mathrm{c}-\mathrm{fos})}$ at various weight ratios of PtCP to si(c-fos). 

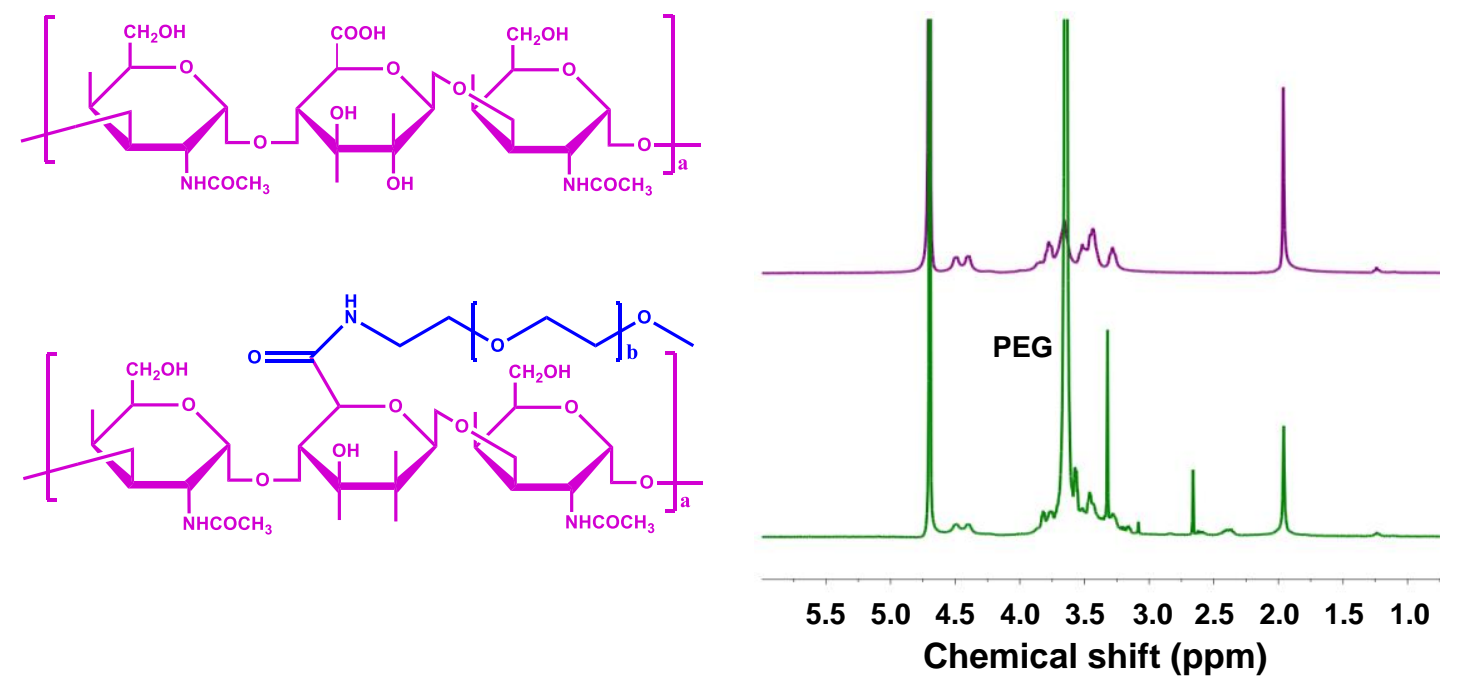

Figure S10. Chemical structures and ${ }^{1} \mathrm{H}$ NMR spectra characterization of HA and HA-PEG (HP). 

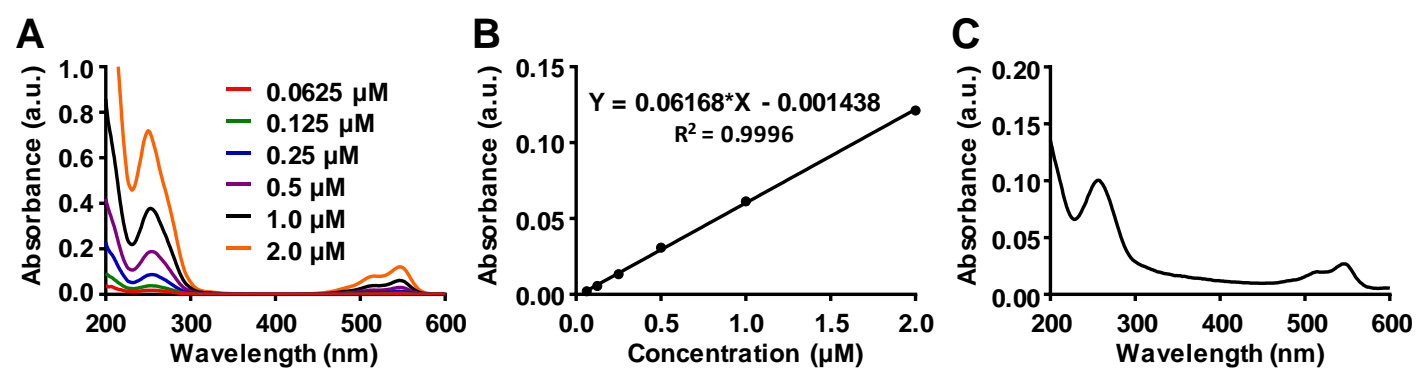

Figure S11. (A) UV-vis spectrum of the different concentration of Cy3-si(c-fos). (B) The standard curve of Cy3-si(c-fos) at $547 \mathrm{~nm}$. (C) UV-vis spectrum of Cy3-si(c-fos) in the supernatant after centrifuging from the $\mathrm{CNP}_{\mathrm{PtCP} / \mathrm{Cy} 3 \text {-si(c-fos) }}$ solution. The loading efficiency of si(c-fos) was determined by the absorption peak and the standard curve of Cy3-si(c-fos) at $547 \mathrm{~nm}$. 
A
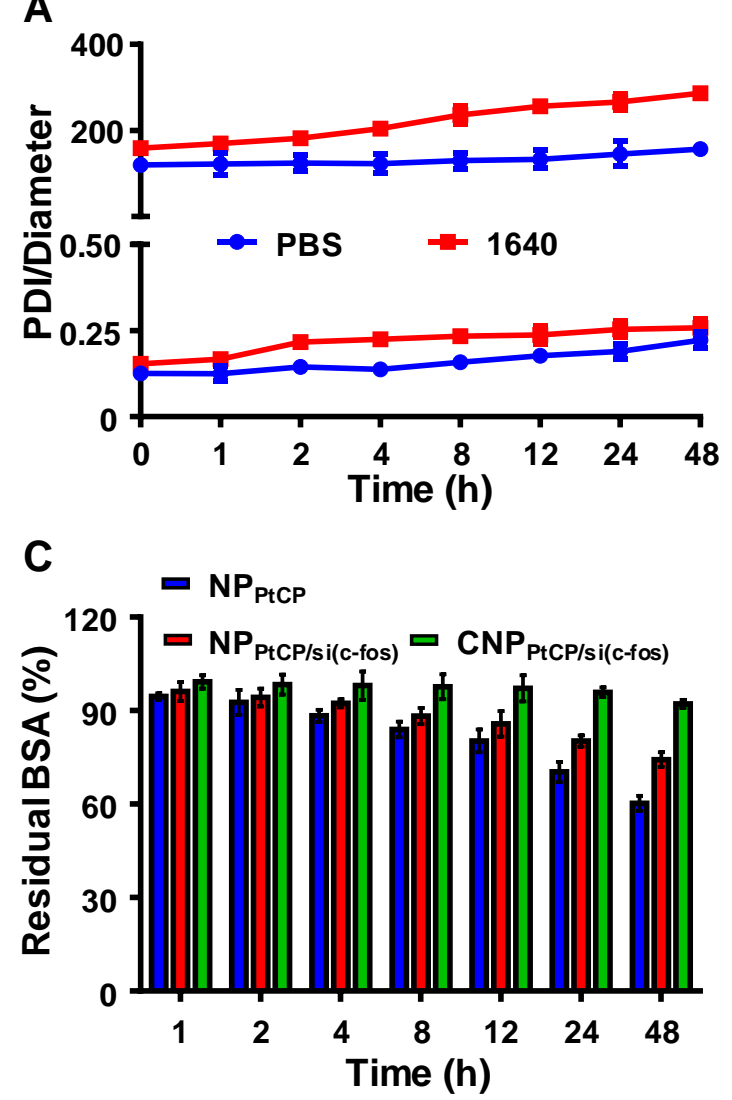

B

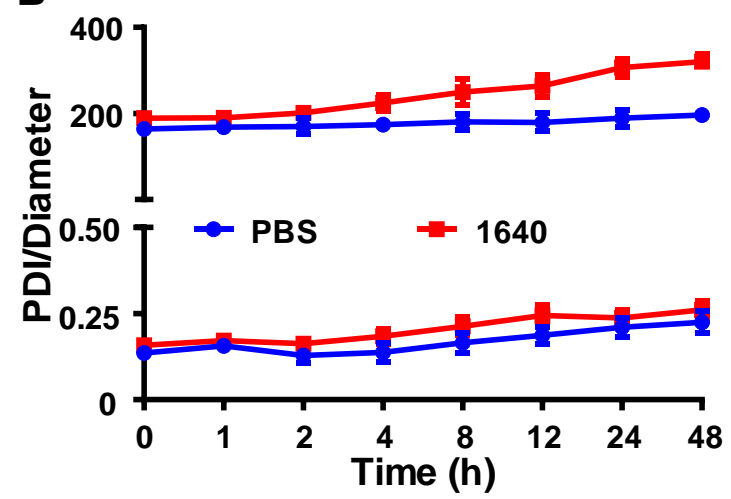

D

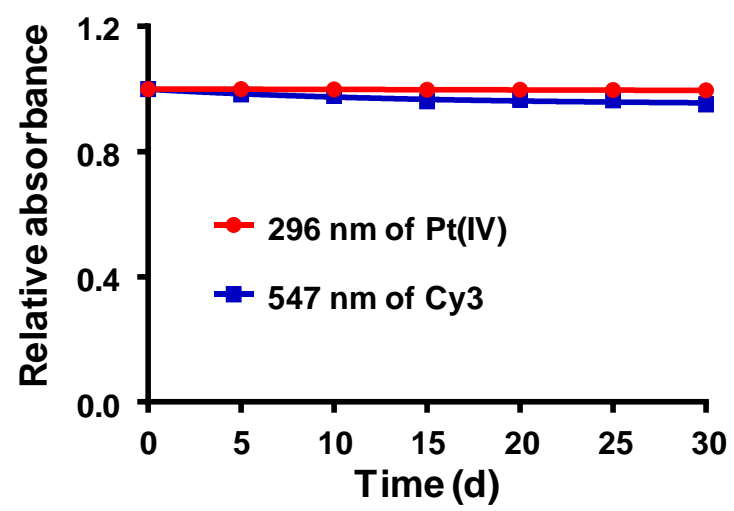

Figure S12. The particle size and PDI changes of (A) $\mathrm{NP}_{\mathrm{PtCP}}$ and (B) $\mathrm{NP}_{\mathrm{PtCP} / \mathrm{si}(\mathrm{c}-\mathrm{fos})}$ in PBS or RPMI 1640 medium (containing 10\% FBS) within 48 h. (C) Anti-protein adsorption ability of $\mathrm{NP}_{\mathrm{PtCP}}, \mathrm{NP}_{\mathrm{PtCP} / \mathrm{si} \text { (c-fos) }}$ and $\mathrm{CNP}_{\mathrm{PtCP} / \mathrm{si} \text { (c-fos). }}$ (D) The dark stability of $\mathrm{CNP}_{\mathrm{PtCP} / \mathrm{Cy} 3 \text {-si(c-fos) }}$ in water by monitoring the characteristic absorbance of $\mathrm{Pt}(\mathrm{IV})$ at $298 \mathrm{~nm}$ and Cy3 at $547 \mathrm{~nm}$. 

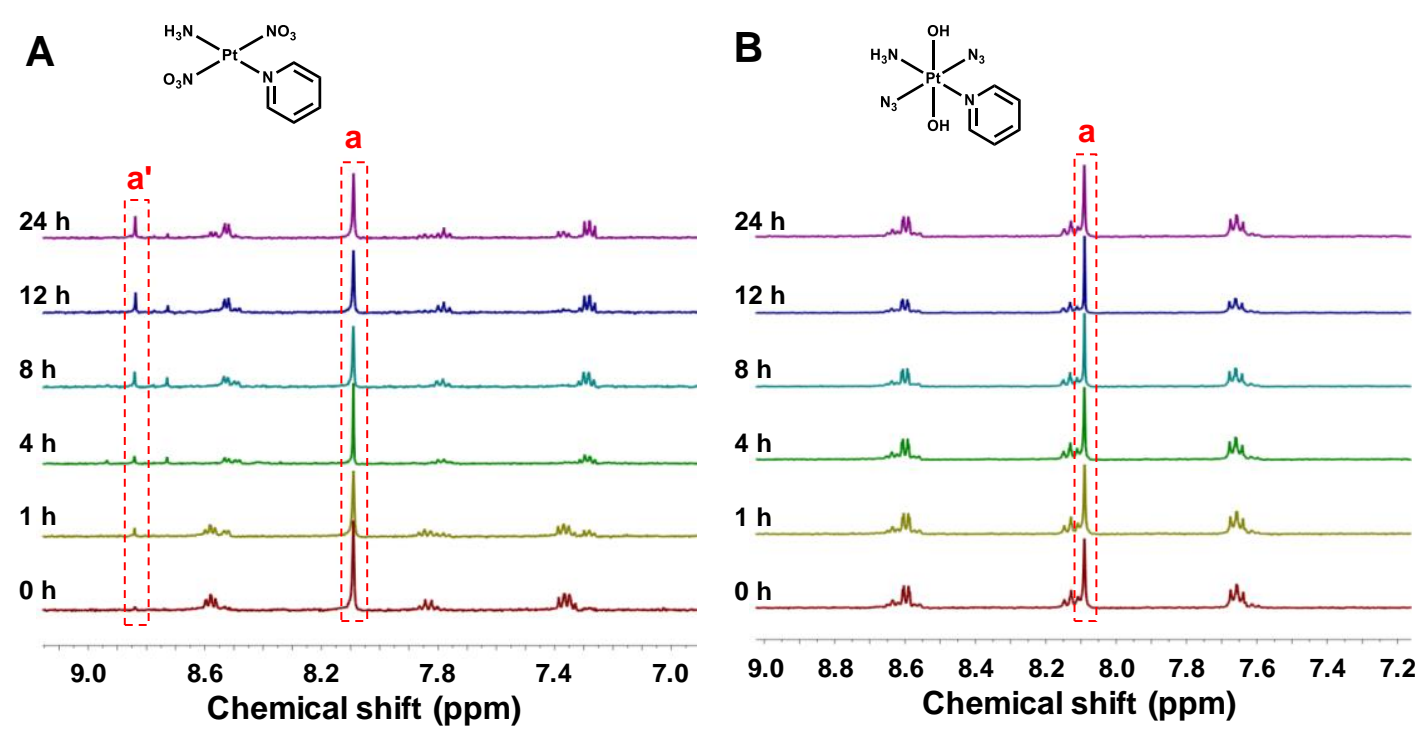

\section{C}

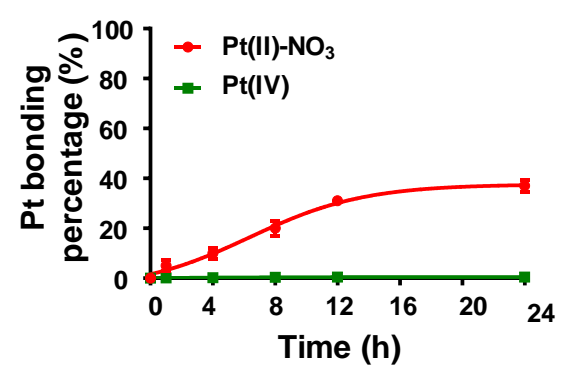

D

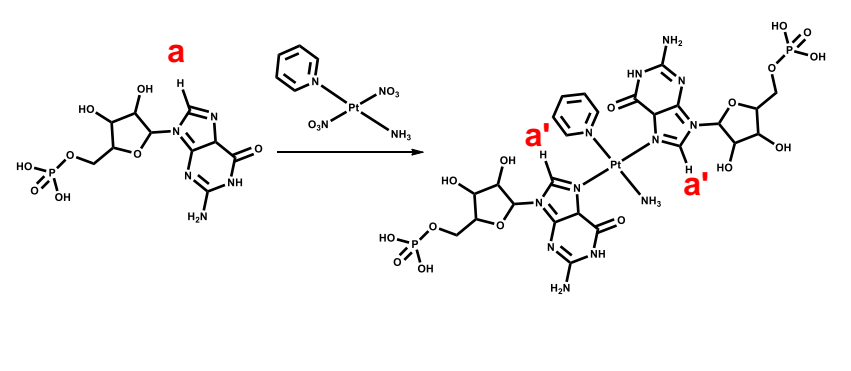

Figure S13. Monitoring the interaction of $\mathrm{Pt}(\mathrm{II})-\mathrm{NO}_{3}$ and $\mathrm{Pt}(\mathrm{IV})$ with 5'-GMP by ${ }^{1} \mathbf{H}$ NMR spectra. ${ }^{1} \mathrm{H}$ NMR trace the reaction of (A) $\mathrm{Pt}(\mathrm{II})-\mathrm{NO}_{3}$ and (B) $\mathrm{Pt}(\mathrm{IV})$ with 5'-GMP. (C) The bonding percentage of $\mathrm{Pt}(\mathrm{II})-\mathrm{NO}_{3}$ and $\mathrm{Pt}(\mathrm{IV})$ with 5'-GMP. (D) The reaction schematic of Pt(II) with 5'-GMP. 
A

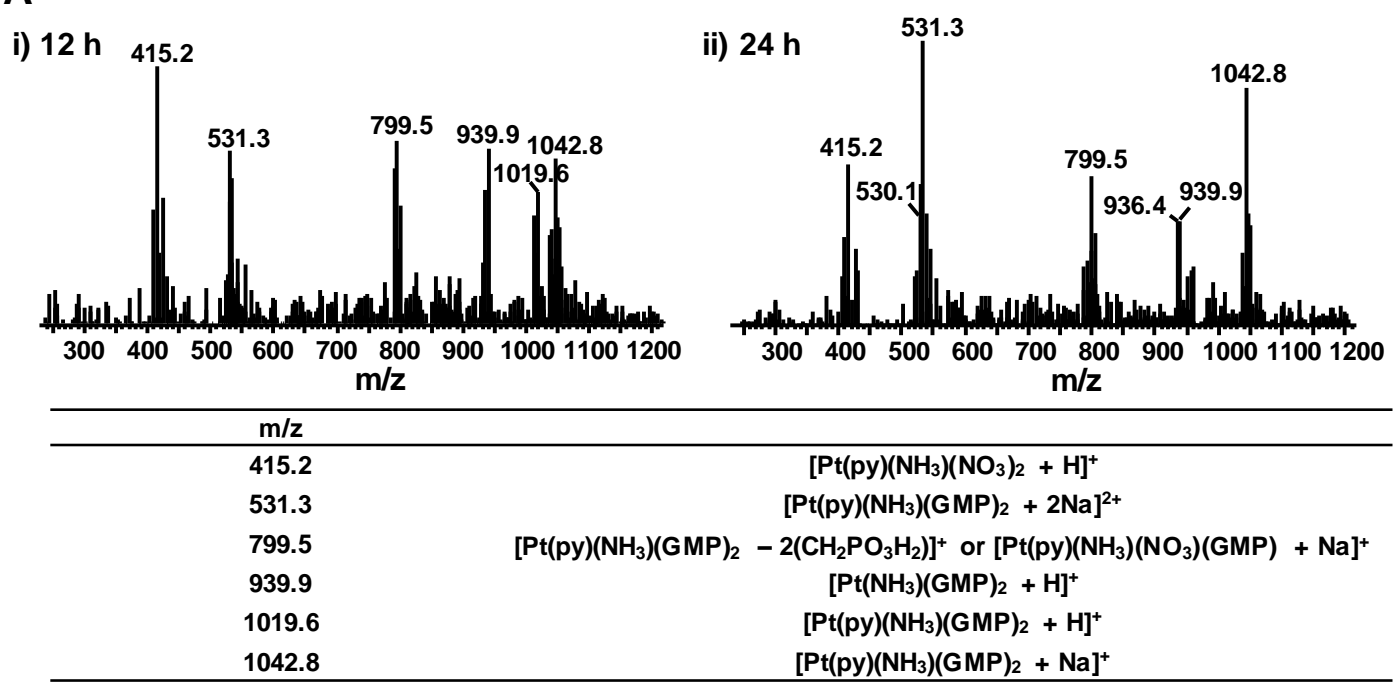

B
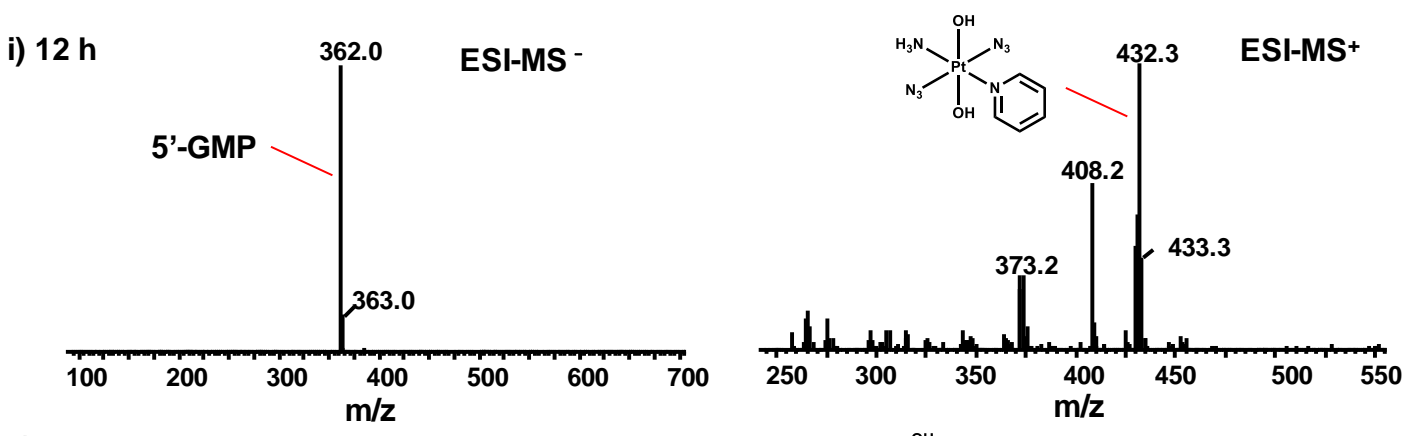

ii) $24 \mathrm{~h}$
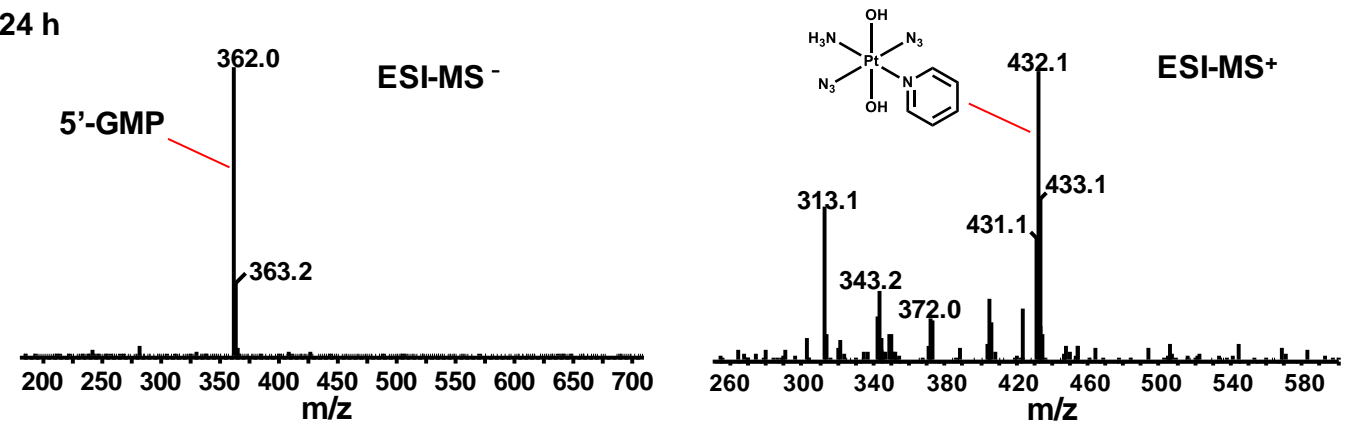

Figure S14. Monitoring the interaction of $\mathrm{Pt}(\mathrm{II})-\mathrm{NO}_{3}$ and $\mathrm{Pt}(\mathrm{IV})$ with 5'-GMP by

ESI-MS. (A) Pt(II) and 5'-GMP incubated for $12 \mathrm{~h}$ (i) and $24 \mathrm{~h}$ (ii). The Pt/5'-GMP adducts are detail list in the table. (B) Pt(IV) and 5'-GMP incubated for (i) $12 \mathrm{~h}$ and (ii) 24 h. No Pt/5'-GMP adducts are appeared and the 5'-GMP or Pt(IV) only can be separate detected by ESI-MS ${ }^{-}$or ESI-MS ${ }^{+}$. 

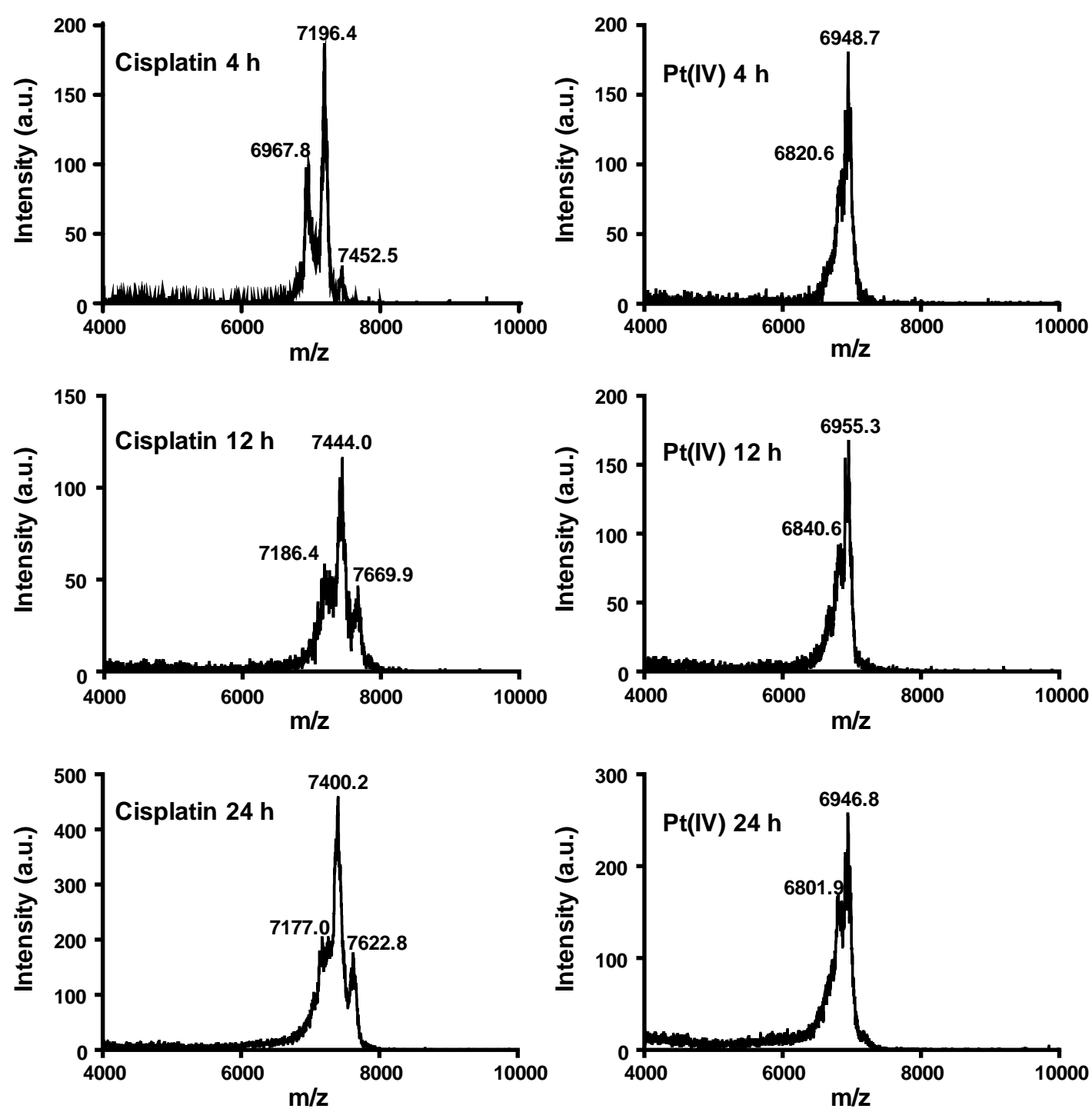

Figure S15. Monitoring the reaction of cisplatin and $\operatorname{Pt}(\mathrm{IV})$ with ss-si(c-fos) by MALDI/TOF-MS. With incubation time prolonged, the intensity of Pt/ss-si(c-fos) adducts was gradually strengthened after interaction between ss-si(c-fos) and cisplatin. While no Pt/ss-si(c-fos) adducts could be detected all the incubation time of ss-si(c-fos) and Pt(IV). 
A

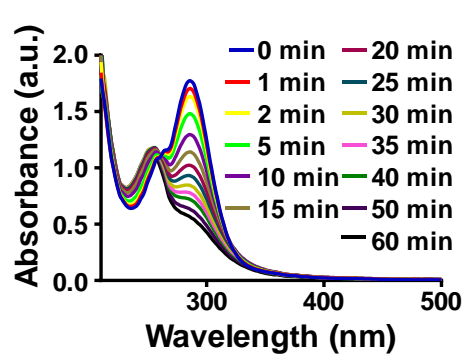

D

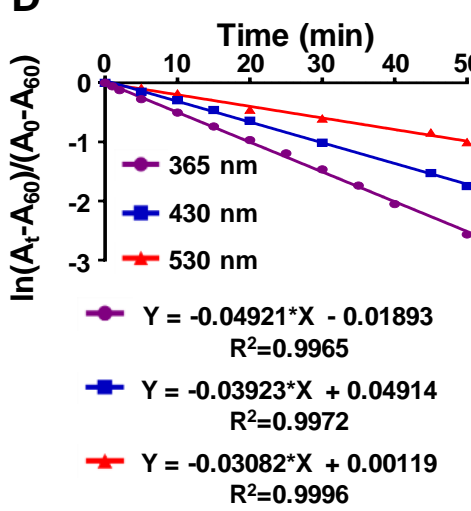

B

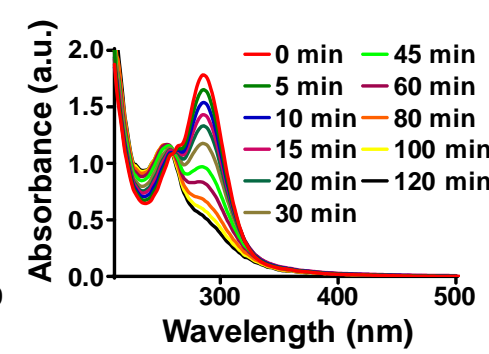

E

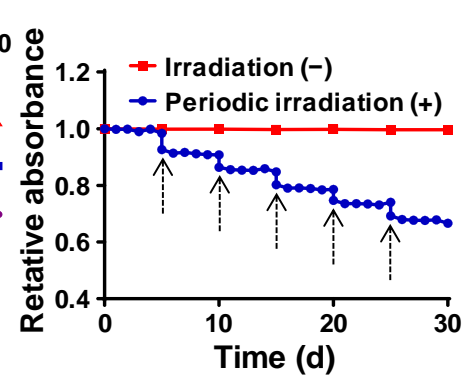

C

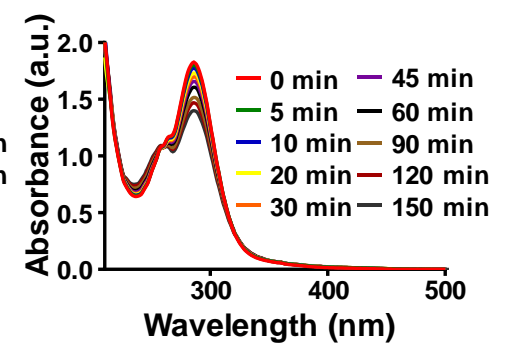

F

- Irradiation (-)
-Irradiation (+)

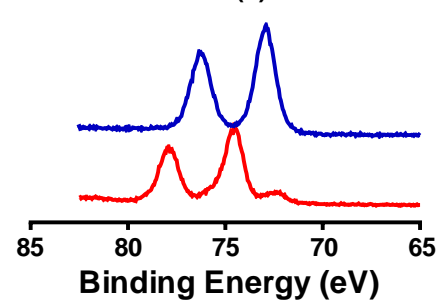

Figure S16. Photo-sensitivity of $\mathrm{Pt}(\mathrm{IV})$. UV-vis spectra changes of $\mathrm{Pt}(\mathrm{IV})$ with different wavelength light irradiation for indicated time intervals: (A) $365 \mathrm{~nm}$, (B) $430 \mathrm{~nm}$ and (C) $530 \mathrm{~nm}$. (D) The first order kinetics of Pt(IV) degradation with visible light irradiation. (E) UV-vis absorption of $\mathrm{Pt}(\mathrm{IV})$ at $290 \mathrm{~nm}$ upon periodic irradiation (irradiation was turned on for 5 min then turned off for 5 days). (F) XPS changes of $\mathrm{Pt}(\mathrm{IV})$ after irradiation for 0 or $60 \mathrm{~min}$. "-" indicated in the dark, “+” indicated with irradiation. Light source: $20 \mathrm{~mW} / \mathrm{cm}^{2}$. 
A

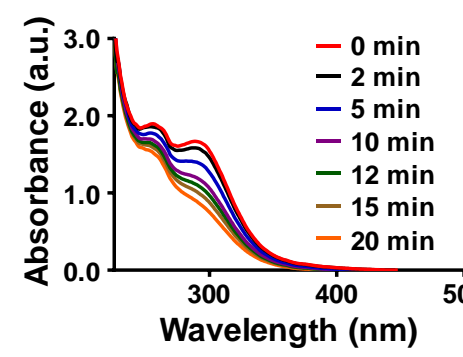

D

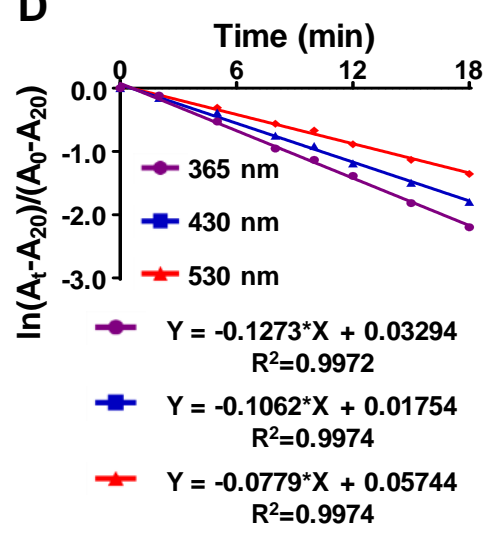

B

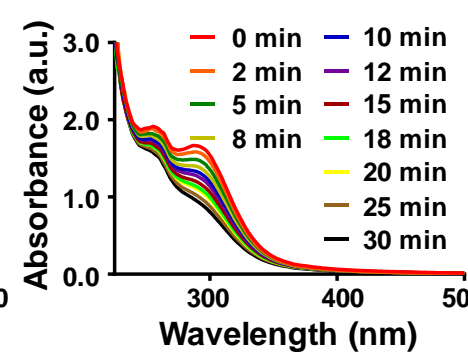

$\mathrm{E}$

$18 \stackrel{8}{8}$

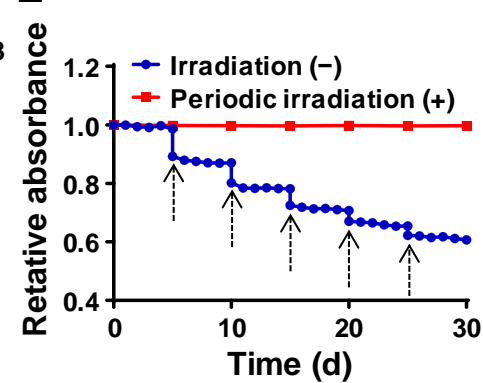

C

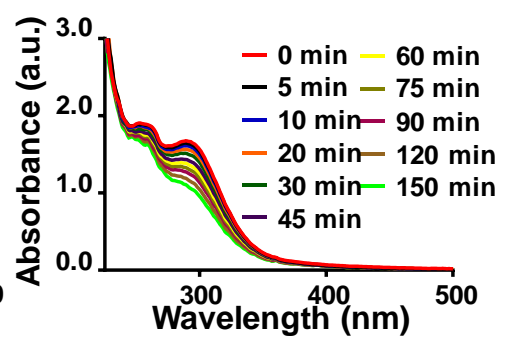

$\mathbf{F}$

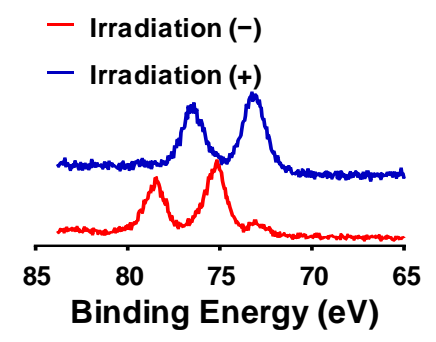

Figure S17. Photo-sensitivity of PtCP. UV-vis spectra changes of PtCP irradiated with different wavelengths of light for indicated time intervals: (A) $365 \mathrm{~nm}$, (B) 430 $\mathrm{nm}$ and (C) $530 \mathrm{~nm}$. (D) The first order kinetics of PtCP degradation with visible light irradiation. (E) UV-vis absorption of PtCP at $290 \mathrm{~nm}$ upon periodic irradiation (irradiation was turned on for 5 min then turned off for 5 days). (F) XPS changes of PtCP after irradiation for 0 or 60 min. "-” indicated in the dark, “+” indicated with irradiation. Light source: $20 \mathrm{~mW} / \mathrm{cm}^{2}$. 
A

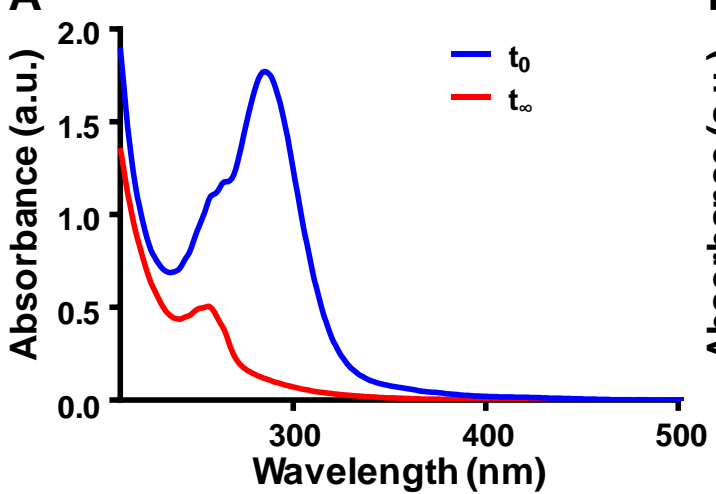

B

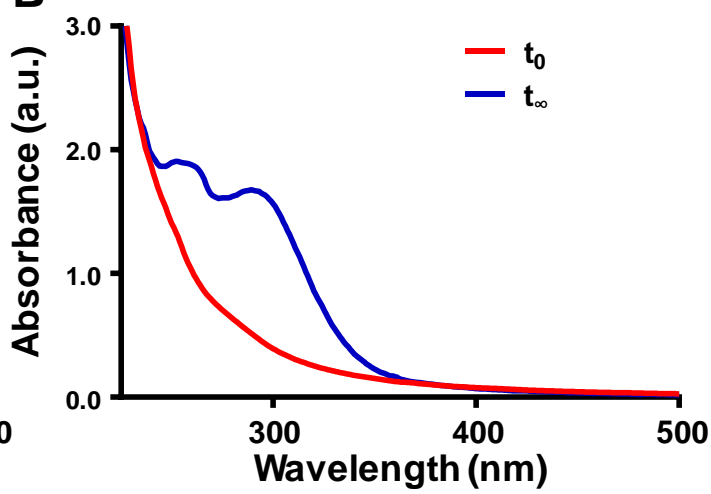

Figure S18. UV-vis spectrum of (A) $\mathrm{Pt}(\mathrm{IV})$ and (B) $\mathrm{PtCP}$ without irradiation and total degradation by light irradiation. Light source: $430 \mathrm{~nm}, 20 \mathrm{~mW} / \mathrm{cm}^{2}$. 
A

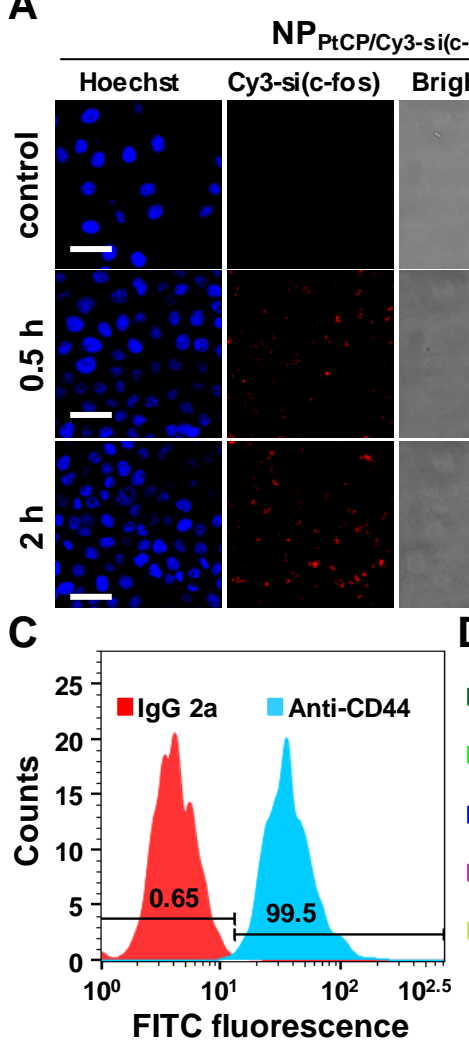

B \begin{tabular}{lll}
\multicolumn{3}{c}{ CNP $_{\text {PtCP/Cy3-si(c-fos) }}$} \\
\hline Hoechst $\quad$ Cy3-si(c-fos) Bright field $\quad$ Merged
\end{tabular}

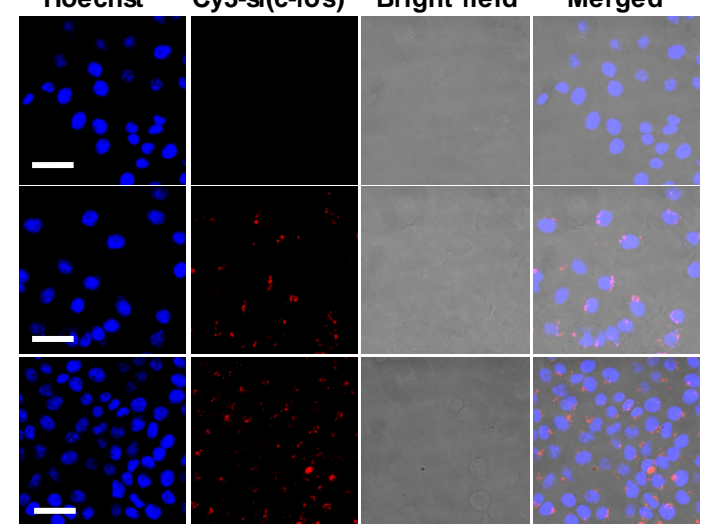

E

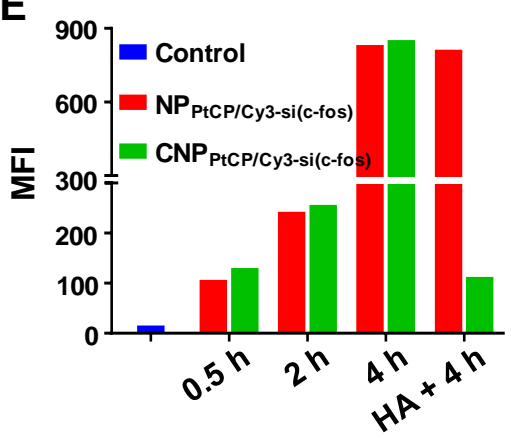

Figure S19. Cellular uptake of $\mathrm{NP}_{\mathrm{PtCP} / \mathrm{Cy} 3 \text {-si(c-fos) }}$ and $\mathrm{CNP}_{\mathrm{PtCP} / \mathrm{Cy} 3-\mathrm{si}(\mathrm{c}-\mathrm{fos})}$. CLSM images of $\mathrm{A} 2780^{\mathrm{DDP}}$ cells after incubation with (A) $\mathrm{NP}_{\mathrm{PtCP} / \mathrm{Cy} 3 \text {-si(c-fos) }}$ or (B) $\mathrm{CNP}_{\mathrm{PtCP} / \mathrm{Cy} 3 \text {-si(c-fos) }}$ for different time intervals (Scale bar $=40 \mu \mathrm{m}$ ). (C) The expression level of CD44 in A $2780^{\mathrm{DDP}}$ cells by flow cytometry. (D) The cellular uptake efficiency of $\mathrm{NP}_{\mathrm{PtCP} / \mathrm{Cy} 3-\mathrm{si}(\mathrm{c}-\mathrm{fos})}$ or $\mathrm{CNP}_{\mathrm{PtCP} / \mathrm{Cy} 3 \text {-si(c-fos) }}$ for different time intervals by flow cytometry. $(\mathrm{E})$ The mean fluorescence intensity (MFI) of cells pre-treated with or without HA and then incubated with $\mathrm{NP}_{\mathrm{PtCP} / \mathrm{Cy} 3-\mathrm{si}(\mathrm{c}-\mathrm{fos})}$ or $\mathrm{CNP}_{\mathrm{PtCP} / \mathrm{Cy} 3-\mathrm{si}(\mathrm{c}-\mathrm{fos})}$ for different time intervals. 
<smiles></smiles>

Pt(IV)<smiles>CC1(C)CCC=[N+]1[O-]</smiles>

DMPO

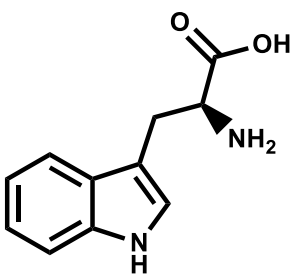

Trp

A
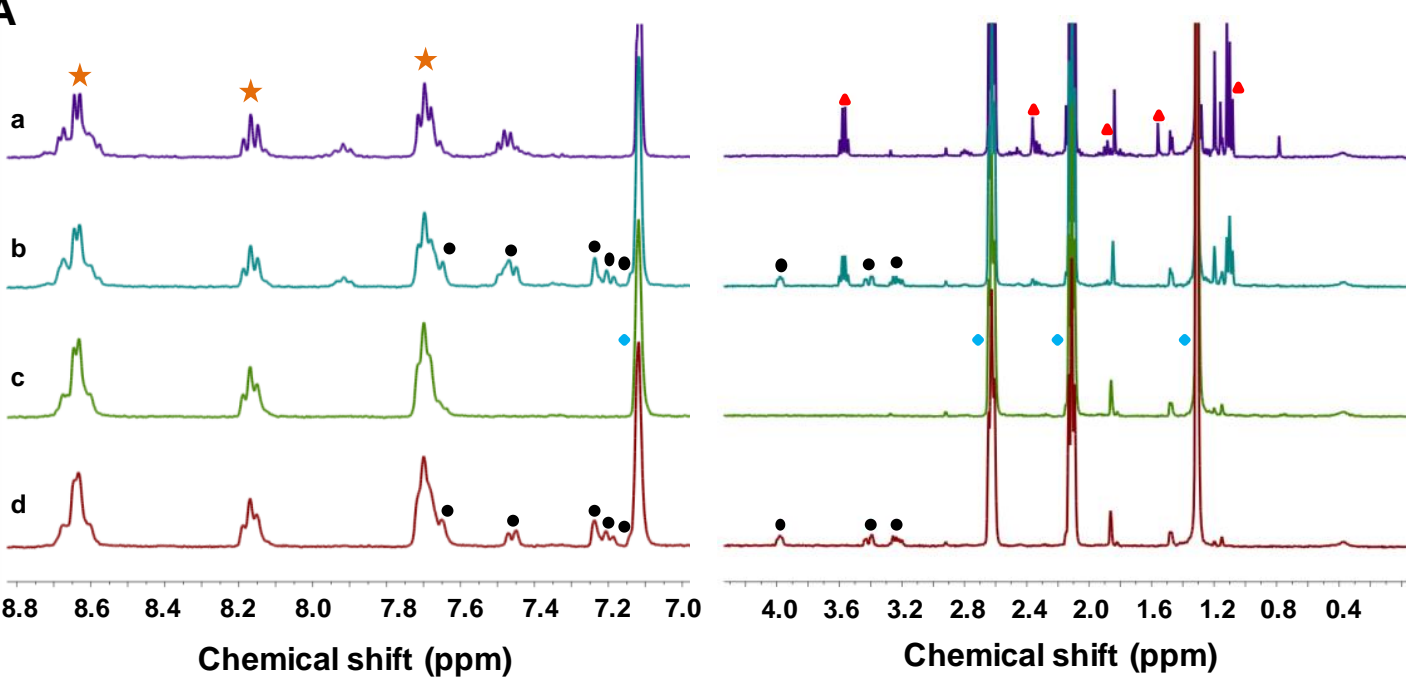

B

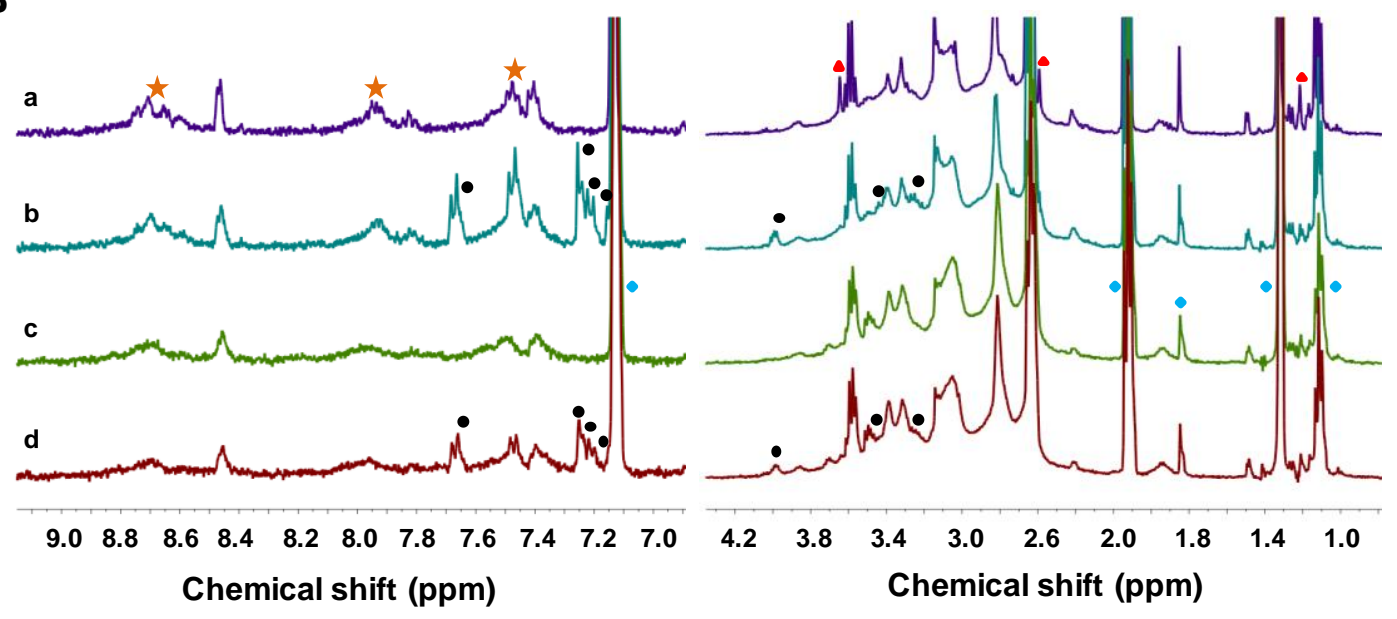

Figure S20. Detection of azidyl radical generated from $\mathrm{Pt}(\mathrm{IV})$ and $\mathrm{PtCP}$ by ${ }^{1} \mathrm{H}$ NMR spectra. (A) ${ }^{1} \mathrm{H}$ NMR spectra of $\mathrm{Pt}(\mathrm{IV})$ and DMPO in $\mathrm{D}_{2} \mathrm{O}$ : (a, c) in the absence of $\operatorname{Trp},(b, d)$ in the presence of $\operatorname{Trp},(a, b)$ irradiation for $30 \mathrm{~min},(\mathrm{c}, \mathrm{d})$ under dark condition. (B) ${ }^{1} \mathrm{H}$ NMR spectra of PtCP and DMPO in $\mathrm{D}_{2} \mathrm{O}$ : $(\mathrm{a}, \mathrm{c})$ in the absence of $\operatorname{Trp},(b, d)$ in the presence of $\operatorname{Trp},(a, b)$ irradiation for $30 \mathrm{~min},(\mathrm{c}, \mathrm{d})$ under dark condition. $\star,{ }^{1} \mathrm{H}$ peaks of $\mathrm{Pt}(\mathrm{IV}) ; \bullet,{ }^{1} \mathrm{H}$ peaks of DMPO; $\bullet,{ }^{1} \mathrm{H}$ peaks of Trp; $\boldsymbol{\Delta}$, ${ }^{1} \mathrm{H}$ peaks of photoproducts of DMPO and azidyl radicals. Light source: $430 \mathrm{~nm}, 20$ $\mathrm{mW} / \mathrm{cm}^{2}$. 


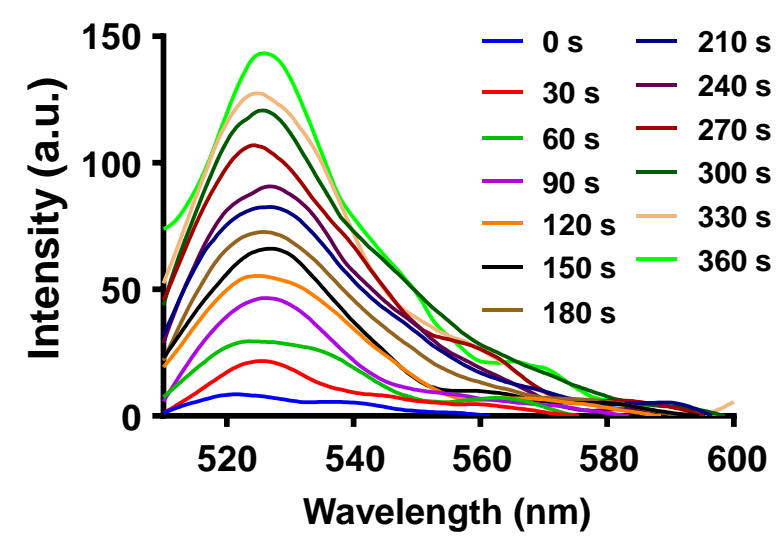

Figure S21. Time-dependent $\mathrm{DCF}$ fluorescence spectra of $\mathrm{CNP}_{\mathrm{PtCP} / \mathrm{si}(\mathrm{c}-\mathrm{fos})}$ with the presence of VC upon irradiation. Light source: $430 \mathrm{~nm}, 20 \mathrm{~mW} / \mathrm{cm}^{2}$. 
A
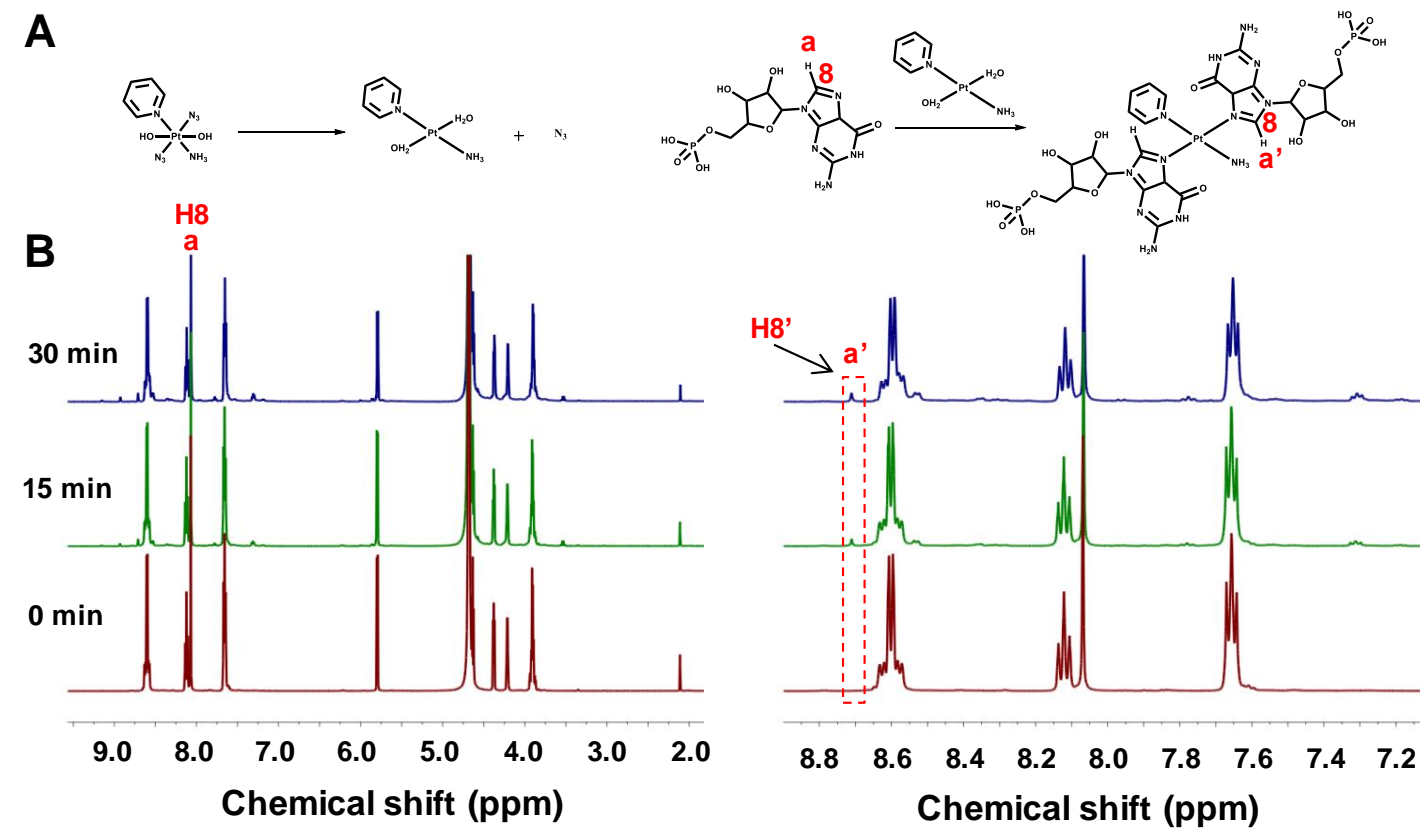

C
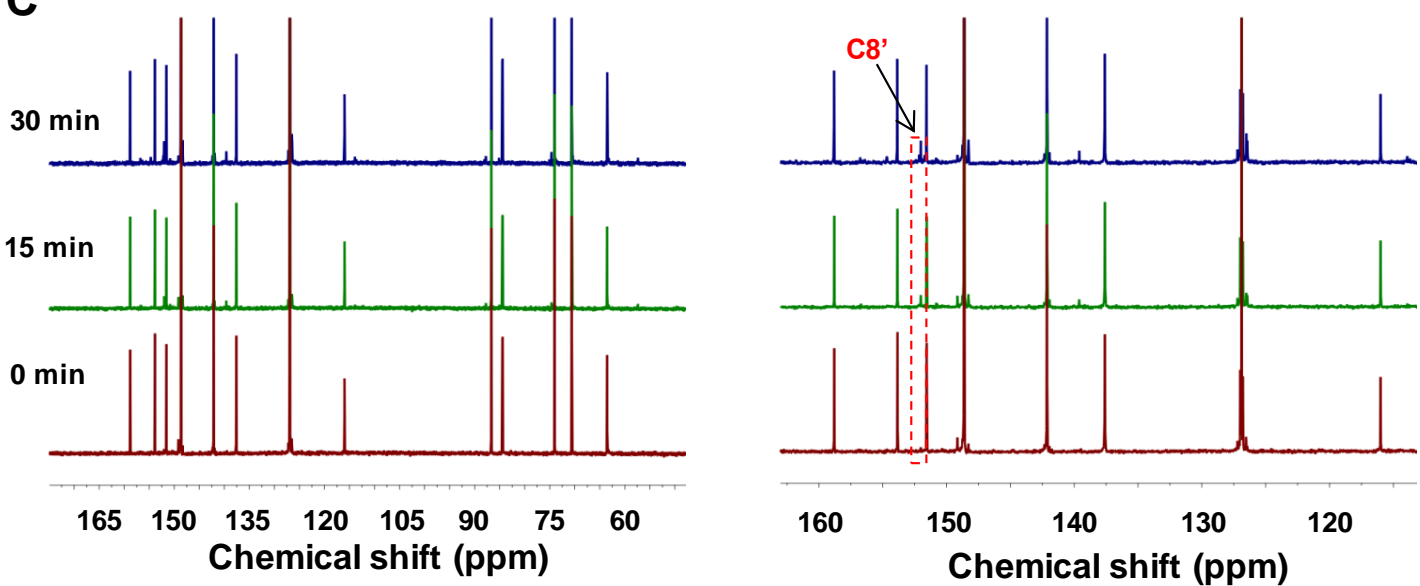

D
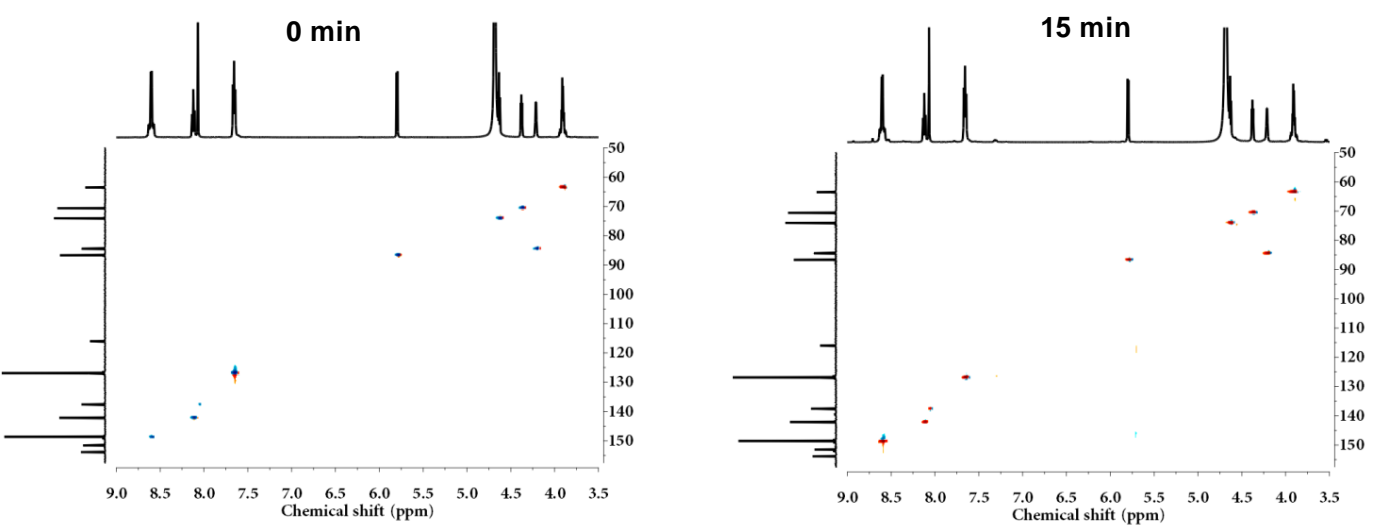

Figure S22. (A) The proposed photodegradation process of $\mathrm{Pt}(\mathrm{IV})$ and the possible interaction of Pt(II) and 5'-GMP. (B) ${ }^{1} \mathrm{H}$ NMR, (C) ${ }^{13} \mathrm{C}$ NMR and (D) $2 \mathrm{D}\left[{ }^{1} \mathrm{H},{ }^{13} \mathrm{C}\right]$ HSQC NMR of the mixed solution of Pt(IV) and 5'-GMP after irradiation for different time intervals. Light source: $430 \mathrm{~nm}, 20 \mathrm{~mW} / \mathrm{cm}^{2}$. 

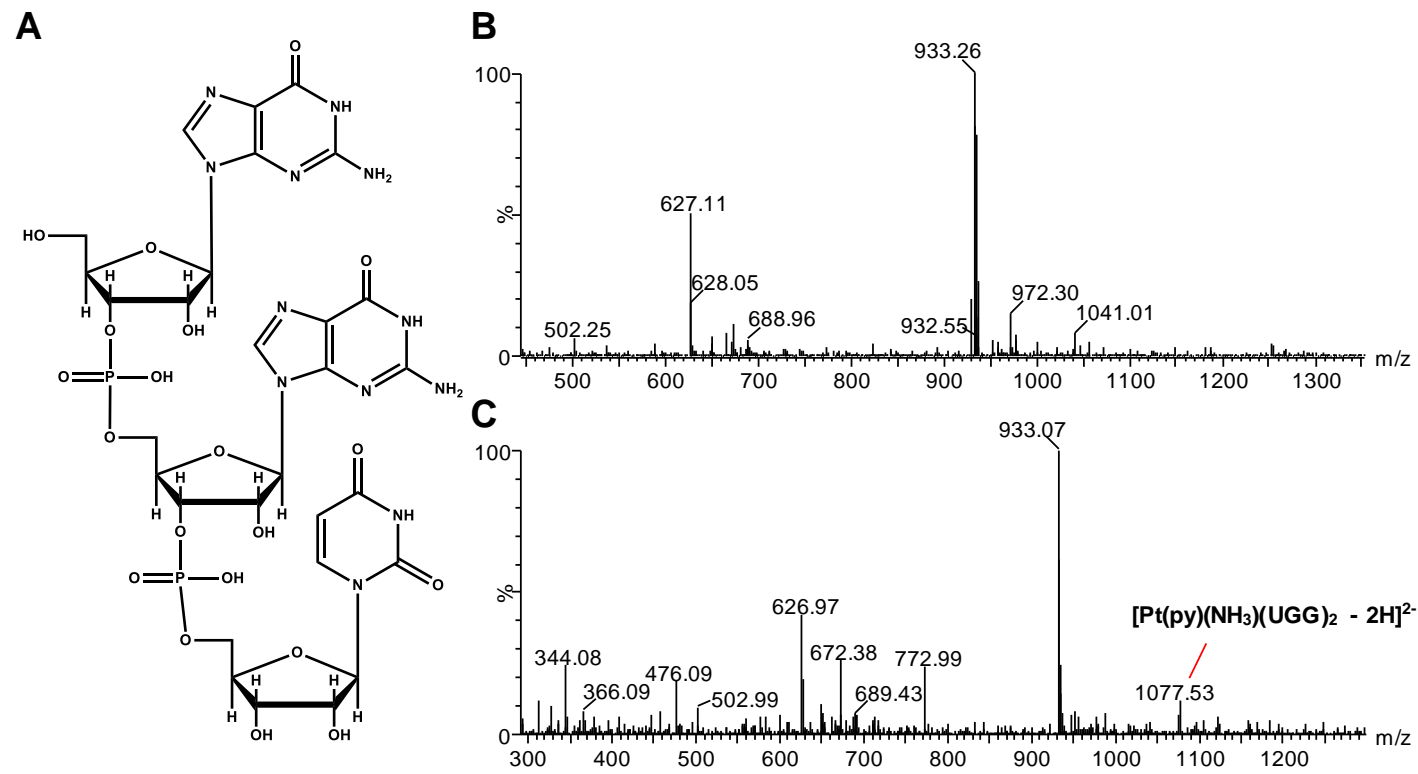

Figure S23. (A) The structural formula of UGG. (B) The mass spectrometry (MS) result of UGG detected by ESI-MS. (C) The MS result of UGG mixed with $1 \mu \mathrm{M}$ of $\mathrm{Pt}(\mathrm{IV})$ after irradiation for different $30 \mathrm{~min}$. Light source: $430 \mathrm{~nm}, 20 \mathrm{~mW} / \mathrm{cm}^{2}$. 
A

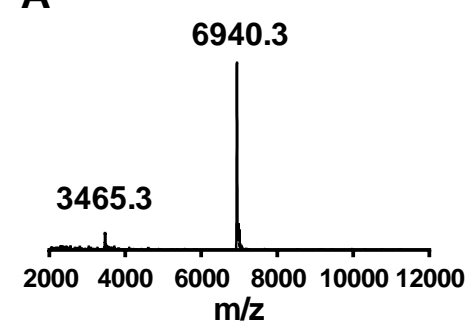

D

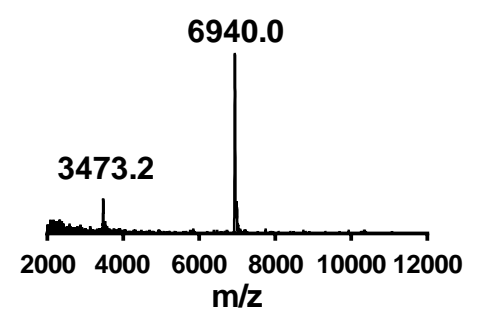

B

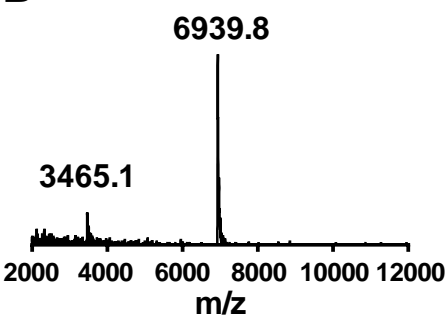

E

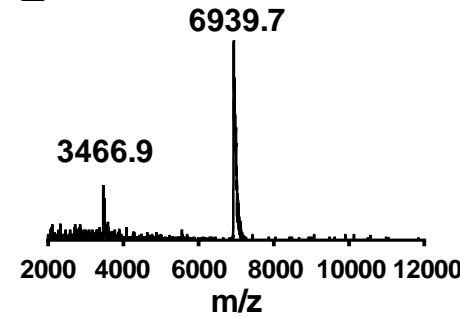

C

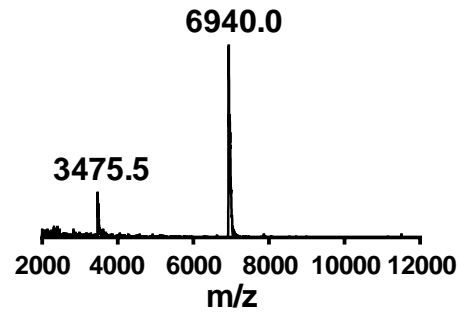

Figure S24. The molecular weight of single strand si(c-fos) after treatment with different concentrations of iodobenzene diacetate and sodium azide ((A) $0 \mu \mathrm{M}$, (B) 1 $\mu \mathrm{M}$ and (C) $10 \mu \mathrm{M})$ or coincubated with different concentrations of $\mathrm{Pt}(\mathrm{IV})((\mathrm{D}) 0 \mu \mathrm{M}$ and (E) $1 \mu \mathrm{M}$ ) and irradiation for $30 \mathrm{~min}$. Light source: $430 \mathrm{~nm}, 20 \mathrm{~mW} / \mathrm{cm}^{2}$. 
A

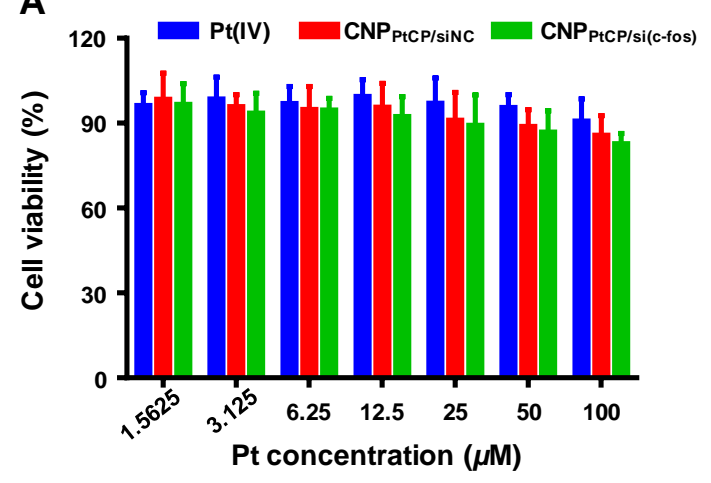

C

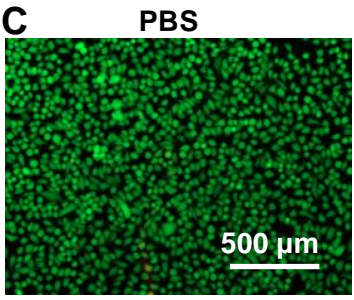

B

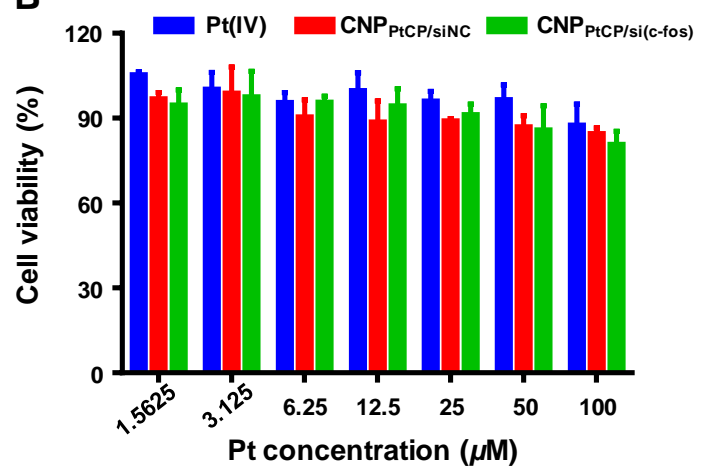

CNP $_{\mathrm{PtCP} / \mathrm{sinC}}$

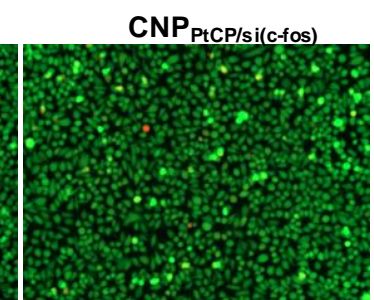

Figure S25. Cell viability curves of different drugs against L929 cells for 2 h (A) or 4

h (B) after light irradiation for 20 min. (C) Fluorescence microscopic images of L929 cells co-stained with calcein AM (green, live cells) and propidium iodide (red, dead cells) after incubation with different drugs at Pt concentration of $50 \mu \mathrm{M}$ with light irradiation for $20 \mathrm{~min}$ and further incubated for $4 \mathrm{~h}$. Light Source: $430 \mathrm{~nm}, 20$ $\mathrm{mW} / \mathrm{cm}^{2}$. 

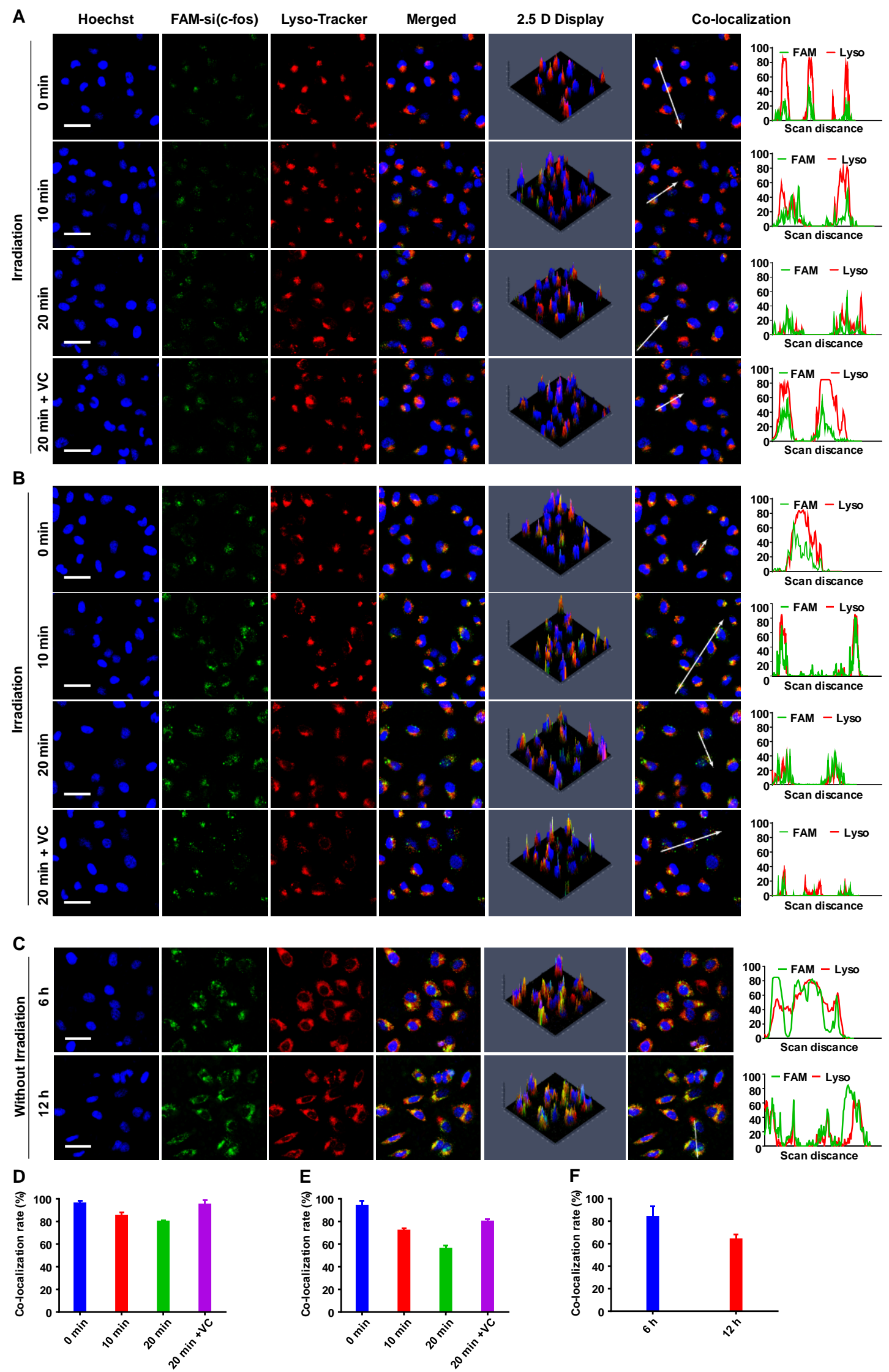
Figure S26. Light-controlled endo/lysosomal escape of CNPPtCP/FAM-si(c-fos). CLSM images and $2.5 \mathrm{D}$ display, the corresponding co-localization fluorescence-intensity-profile analysis and co-localization ratio between FAM-si(c-fos) (green fluorescence) and endo/lysosomes (red fluorescence) in A2780 ${ }^{\mathrm{DDP}}$ cells after treatment with $\mathrm{CNP}_{\mathrm{PtCP} / \mathrm{FAM} \text {-si(c-fos) }}$ in the absence or presence of $\mathrm{VC}$ for $0.5 \mathrm{~h}(\mathrm{~A}, \mathrm{D})$ and $2 \mathrm{~h}(\mathrm{~B}, \mathrm{E})$ with or without irradiation for different time intervals. Scale bar $=40$ $\mu \mathrm{m}$. (C, F) CLSM images and 2.5 D display, the corresponding co-localization fluorescence-intensity-profile analysis and co-localization ratio between FAM-si(c-fos) (green fluorescence) and endo/lysosomes (red fluorescence) in $\mathrm{A} 2780^{\mathrm{DDP}}$ cells after treatment with $\mathrm{CNP}_{\mathrm{PtCP} / \mathrm{FAM} \text {-si(c-fos) }}$ for 6 or $12 \mathrm{~h}$ without irradiation. Scale bar $=40 \mu \mathrm{m}$. Light source: $430 \mathrm{~nm}, 20 \mathrm{~mW} / \mathrm{cm}^{2}$. 


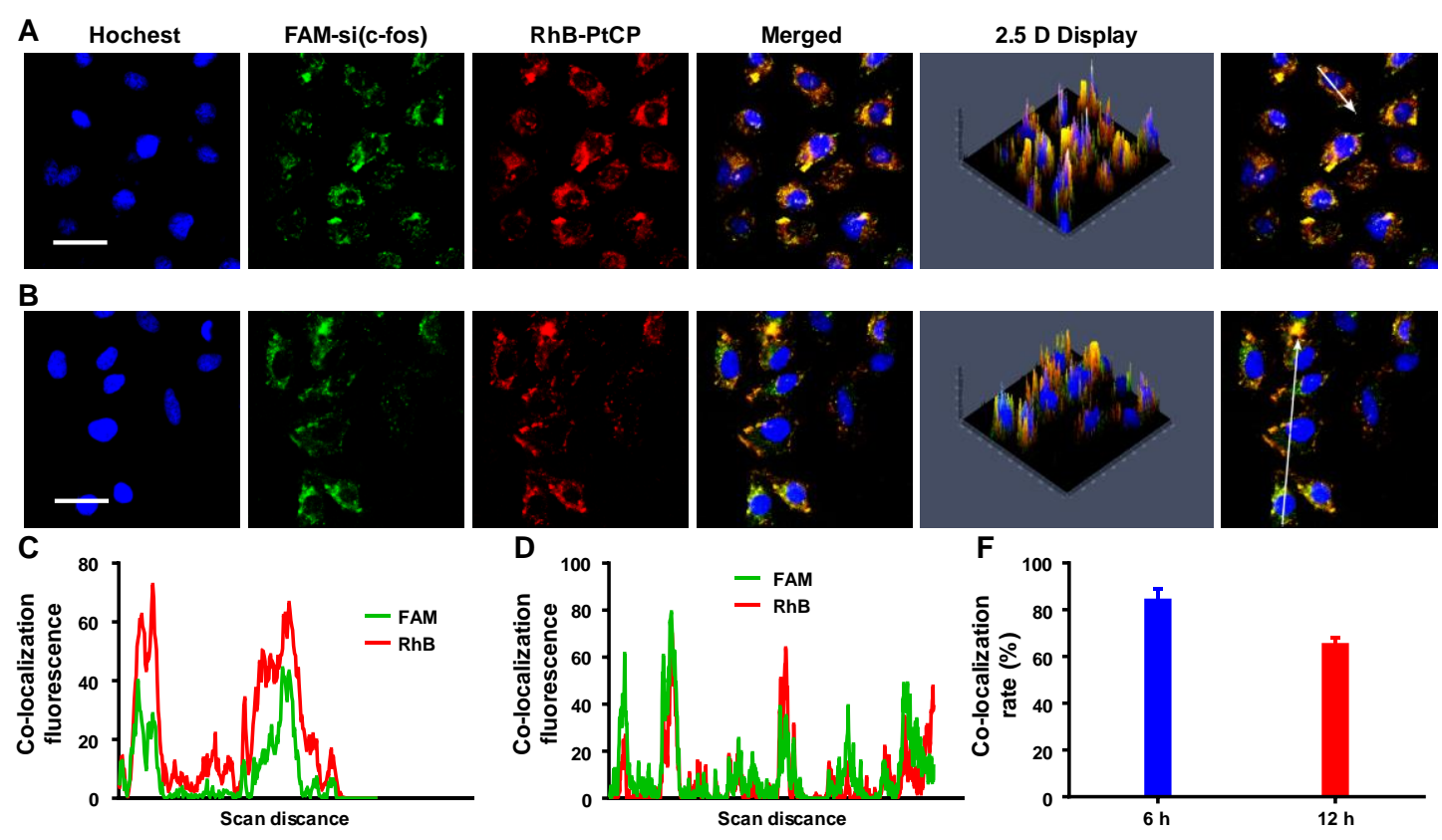

Figure S27. CLSM images and 2.5 D display, the corresponding co-localization fluorescence intensity profile, and co-localization ratio (F) between FAM-si(c-fos) (green fluorescence) and RhB-PtCP (red fluorescence) in $\mathrm{A} 2780^{\mathrm{DDP}}$ cells after $\mathrm{CNP}_{\mathrm{RhB}-\mathrm{PtCP} / \mathrm{FAM} \text {-si(c-fos) }}$ treatment for $6 \mathrm{~h}(\mathrm{~A}, \mathrm{C})$ or $12 \mathrm{~h}(\mathrm{~B}, \mathrm{D})$ without irradiation. Scale bar $=40 \mu \mathrm{m}$. 


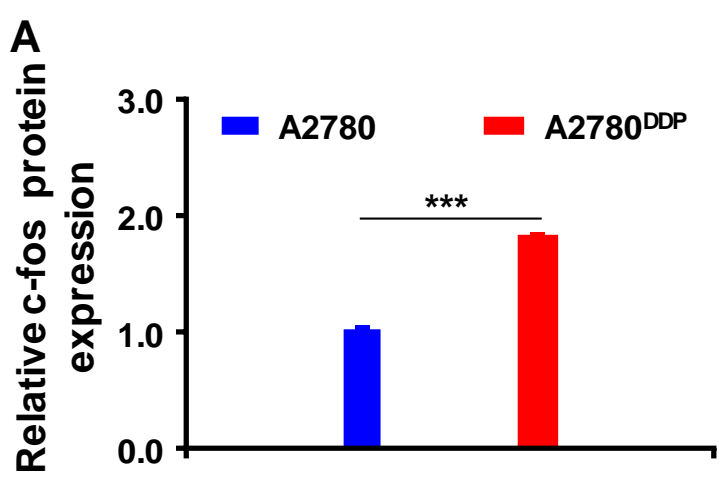

B

Figure S28. The c-fos protein expression levels of A2780 and A2780 ${ }^{\mathrm{DDP}}$ cells by (A) western blotting and (B) immunofluorescence assays. 
A
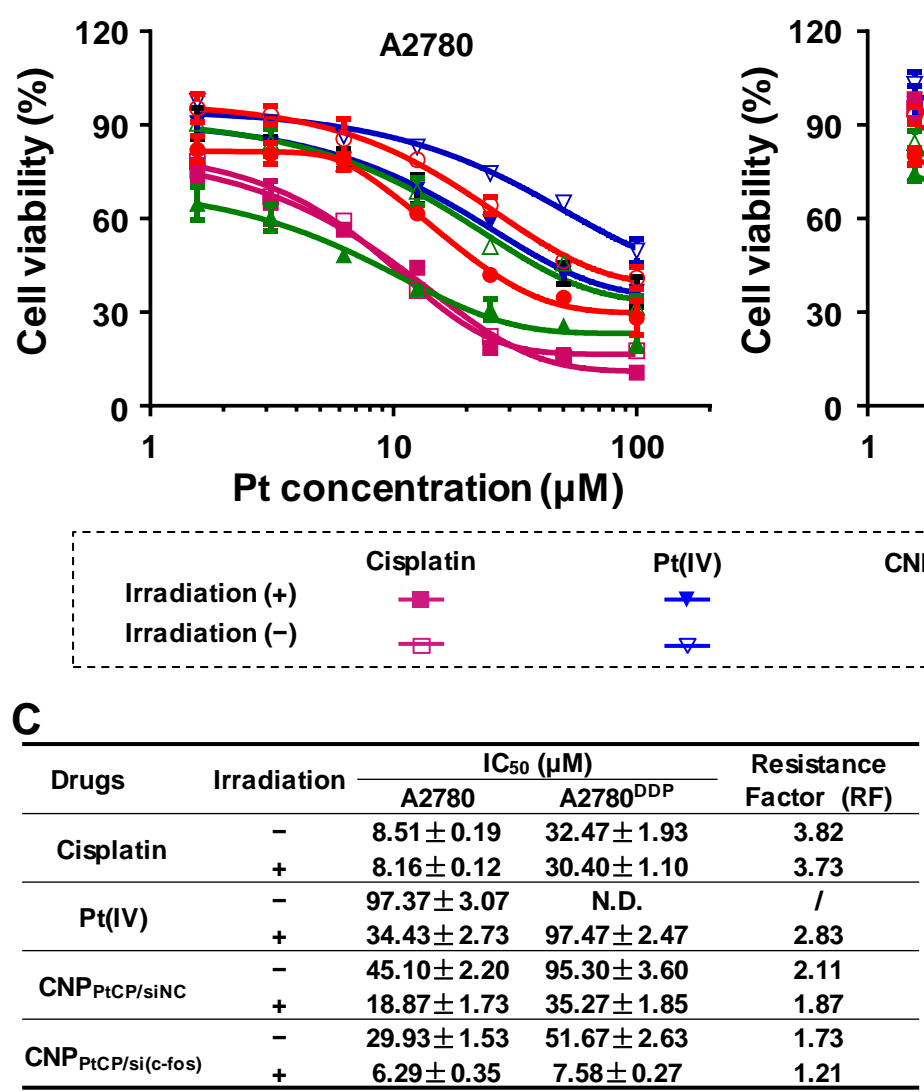

B

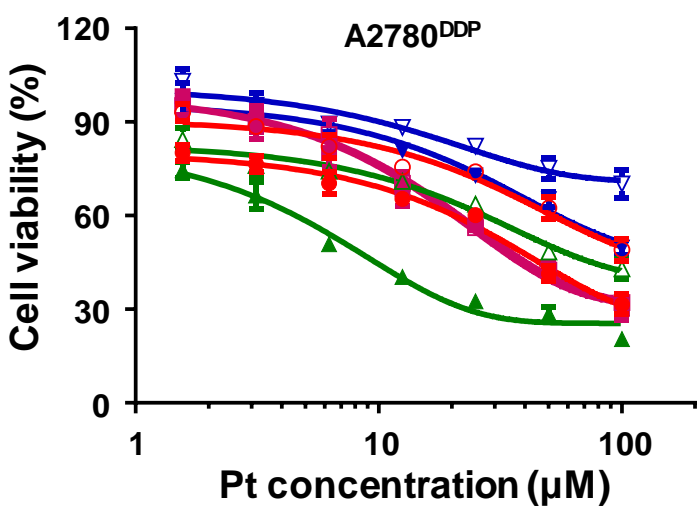

\section{Pt concentration $(\mu \mathrm{M})$}
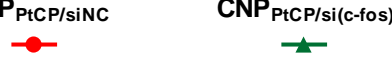

$\odot$

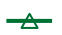

D

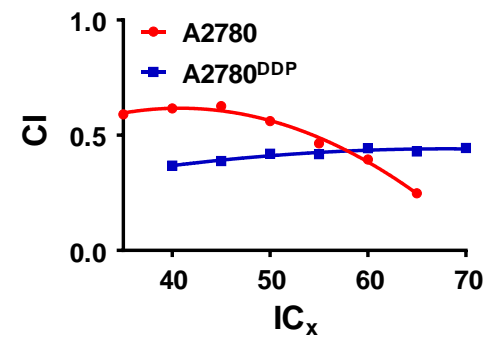

Figure S29. Cytotoxicity of $\mathrm{CNP}_{\mathrm{PtCP} / \mathrm{si}(\mathrm{c} \text {-fos) }}$ against $\mathrm{A} 2780$ and $\mathrm{A} 2780^{\mathrm{DDP}}$ cells for 48 $\mathrm{h}$ incubation with or without irradiation. Cell viability curves of (A) A2780 and (B) $\mathrm{A} 2780^{\mathrm{DDP}}$ after incubation with different drugs. (C) $\mathrm{IC}_{50}$ values $(\mu \mathrm{M})$ and resistance factors (RF) of different drugs against different cells (N.D. indicated not detected). (D) Combination index (CI) curves of $\mathrm{Pt}(\mathrm{IV})$ and si(c-fos) in $\mathrm{CNP}_{\mathrm{PtCP} / \mathrm{si}(\mathrm{c}-\mathrm{fos})}$ against different cells after $48 \mathrm{~h}$ incubation under irradiation. "_" indicated in the dark, "+" indicated with irradiation. Light source: $430 \mathrm{~nm}, 20 \mathrm{~mW} / \mathrm{cm}^{2}, 20 \mathrm{~min}$. 


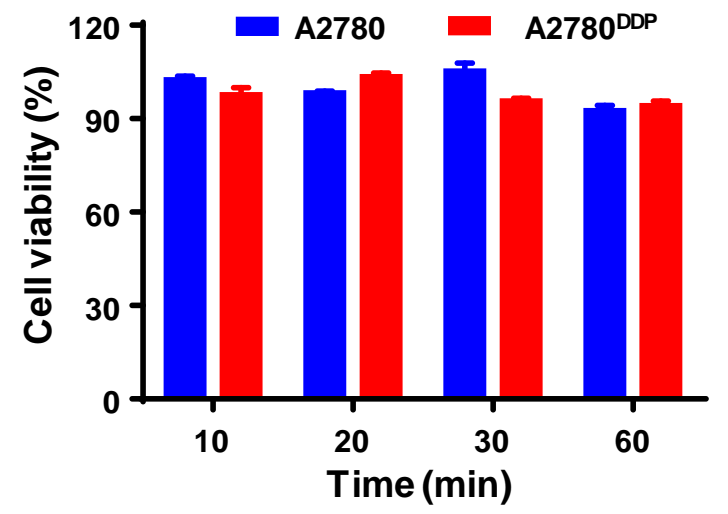

Figure S30. Photo-toxicity evaluation of visible light $\left(430 \mathrm{~nm}, 20 \mathrm{~mW} / \mathrm{cm}^{2}\right)$ against A2780 and A2780 ${ }^{\mathrm{DDP}}$ cells. The cells were irradiated for different time intervals and further incubated for $48 \mathrm{~h}$. 
A

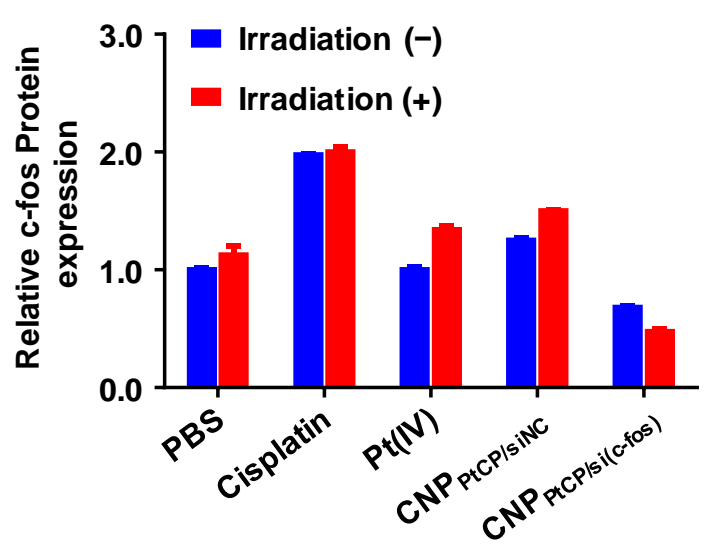

C

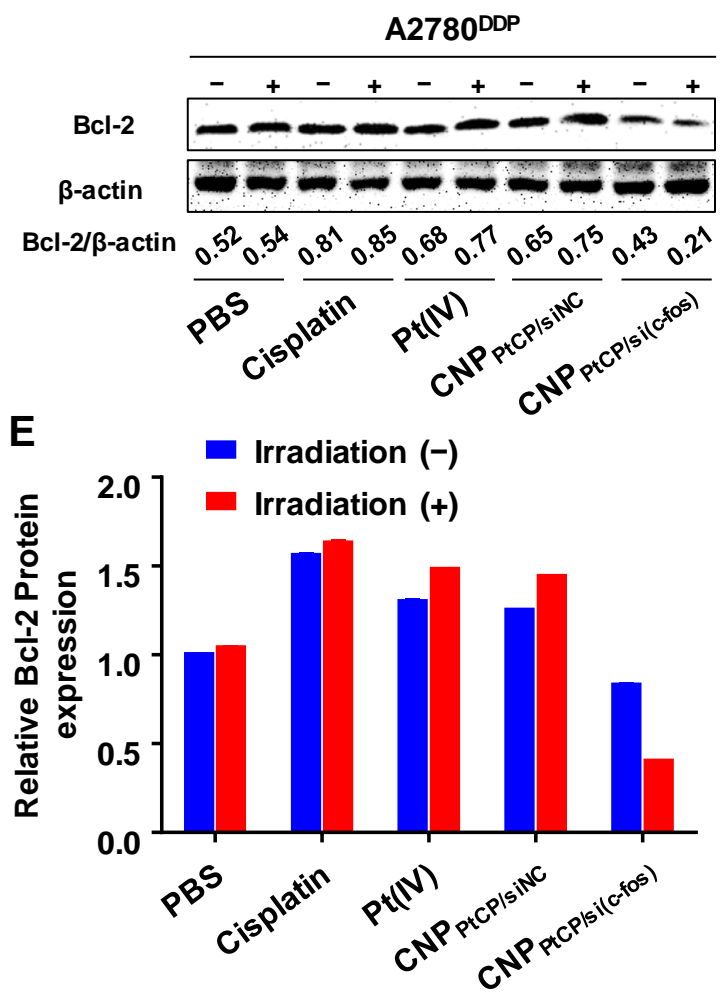

B

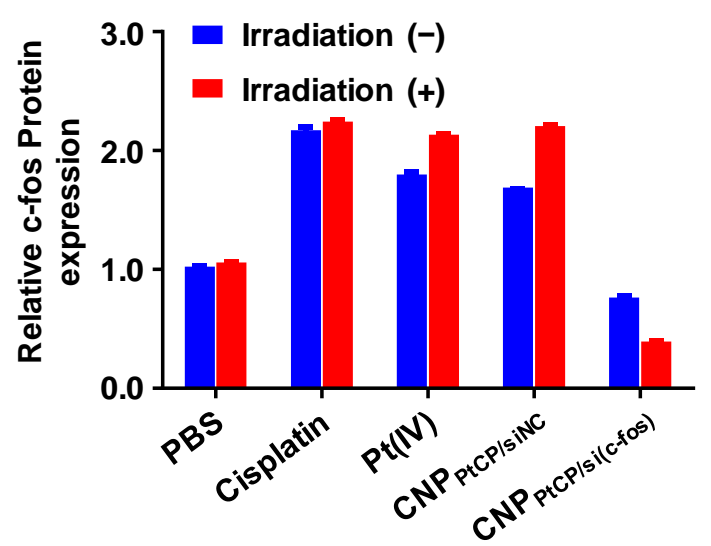

D
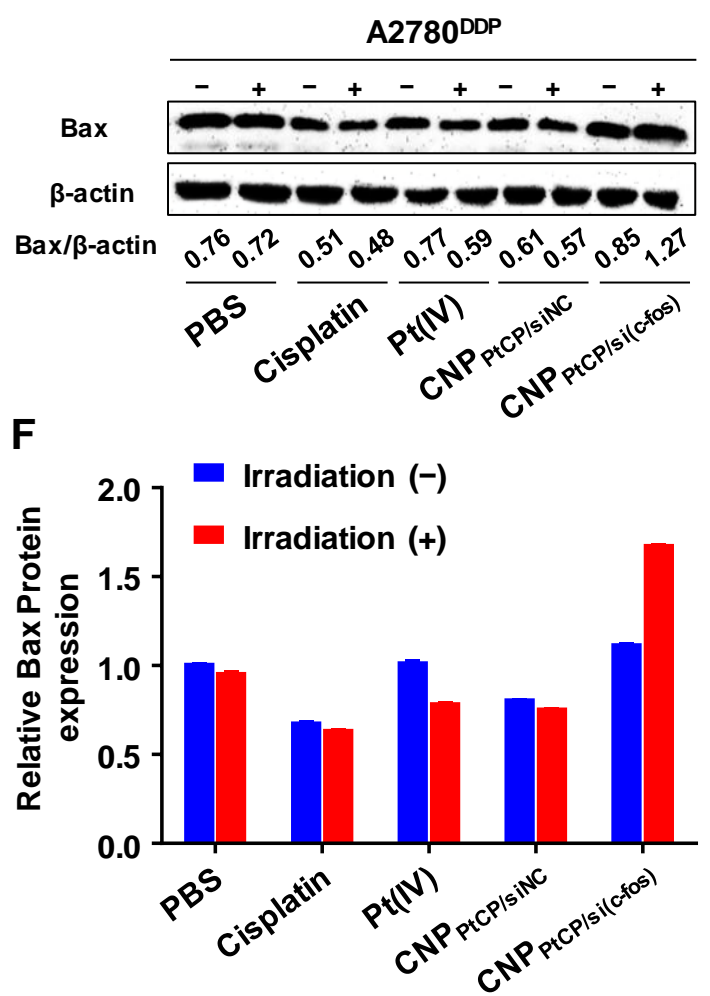

Figure S31. Relative c-fos protein expression levels of (A) A2780 and (B) A2780 ${ }^{\mathrm{DDP}}$. Bcl-2 (C, E) and Bax (D, F) protein expression levels of $\mathrm{A} 2780^{\mathrm{DDP}}$ cells after treatment with different drugs with or without irradiation. "-" indicated in the dark, “+” indicated with irradiation. Light source: $430 \mathrm{~nm}, 20 \mathrm{~mW} / \mathrm{cm}^{2}, 20 \mathrm{~min}$. 


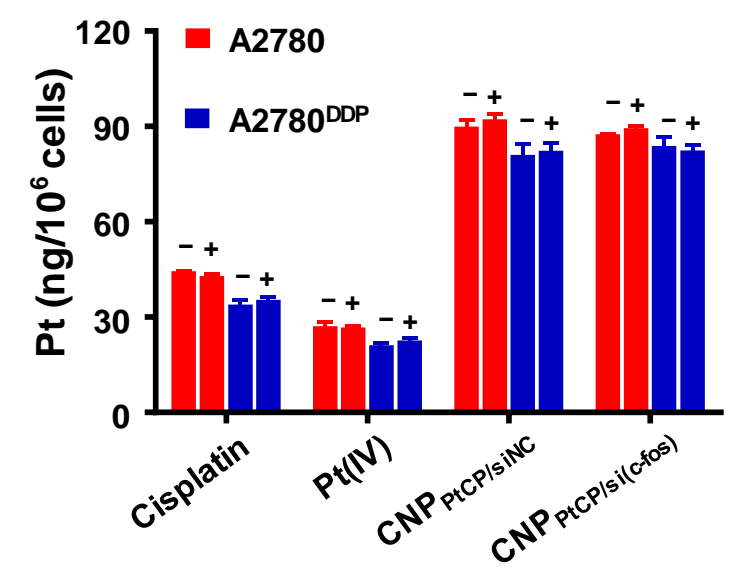

Figure S32. Platinum uptake of A 2780 and A2780 ${ }^{\mathrm{DDP}}$ cells after different treatments. “-” indicated in the dark, “+” indicated with irradiation. Light source: $430 \mathrm{~nm}, 20$ $\mathrm{mW} / \mathrm{cm}^{2}, 20 \mathrm{~min}$. 
A

A2780 Irradiation (-)

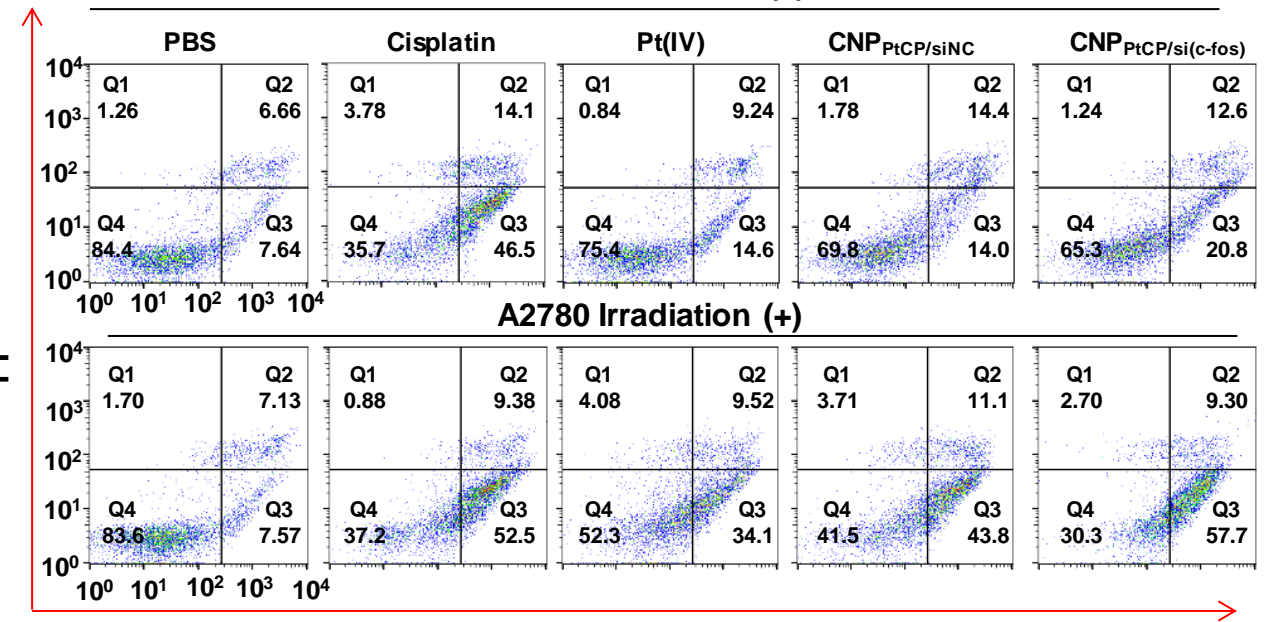

B

Annexin-v-FITC

A2780 DDP Irradiation (-)

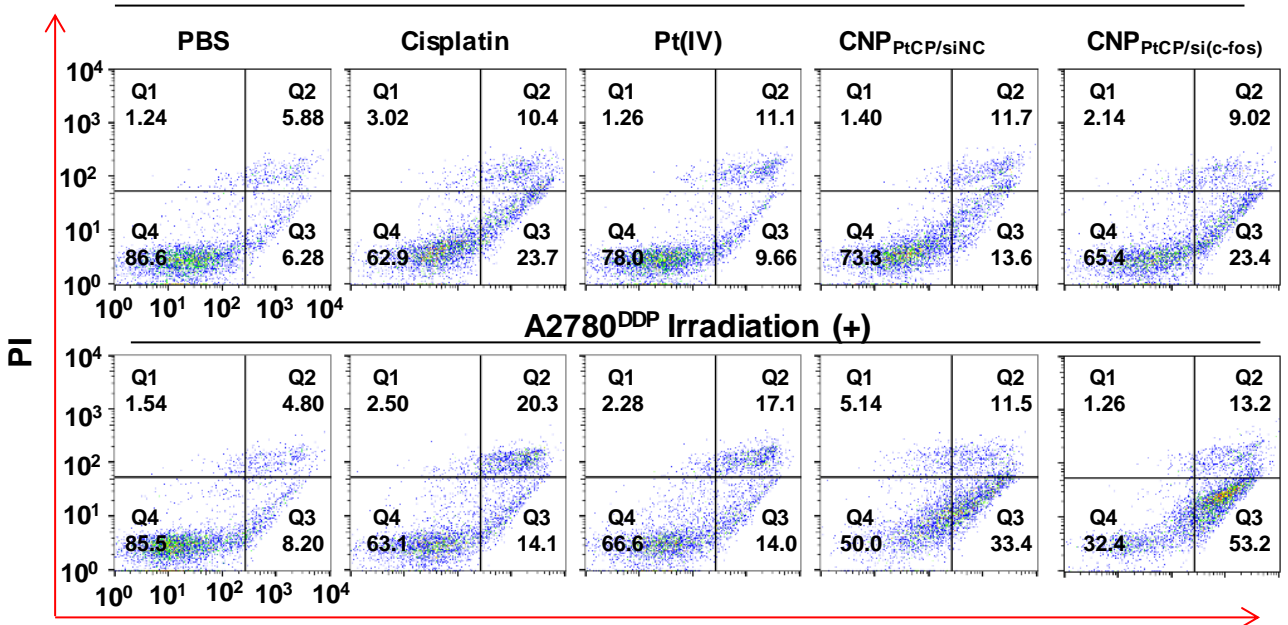

\section{Annexin-v-FITC}

C

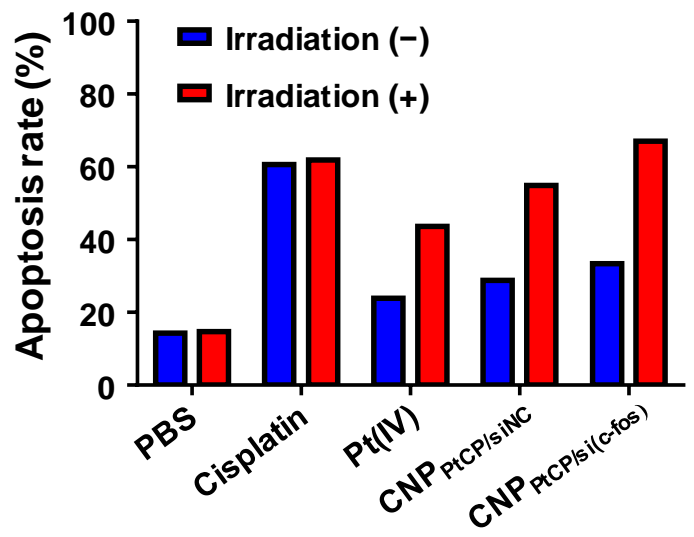

D

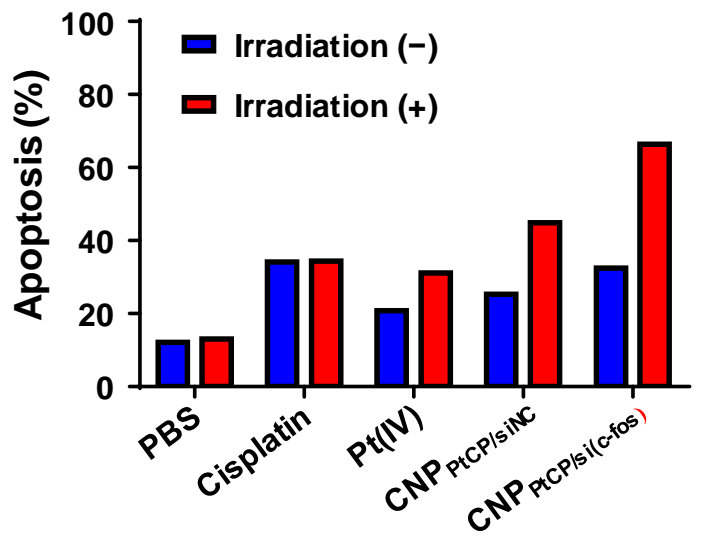

Figure S33. Apoptosis analysis of (A, C) A2780 and (B, D) A2780 ${ }^{\mathrm{DDP}}$ cells after incubation with different drugs for $24 \mathrm{~h}$ with or without irradiation by flow cytometry. “-" indicated in the dark, "+" indicated with irradiation. Light source: $430 \mathrm{~nm}, 20$ $\mathrm{mW} / \mathrm{cm}^{2}, 20 \mathrm{~min}$. 

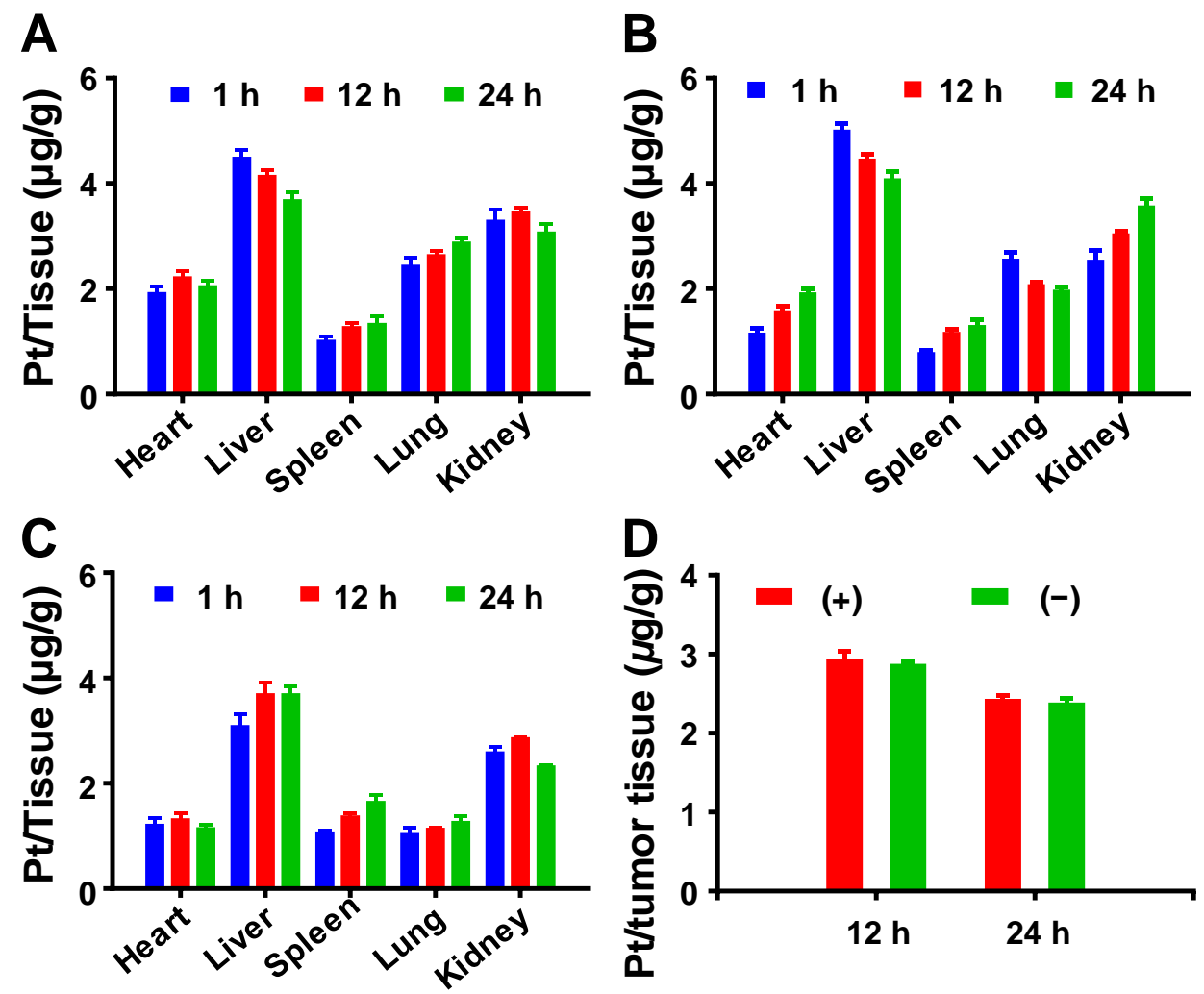

Figure S34. Pt distribution on tumor-bearing mice measured by ICP-MS after intravenous injection of (A) cisplatin, (B) $\mathrm{NP}_{\mathrm{PtCP} / \mathrm{si}(\mathrm{c}-\mathrm{fos})}$ and (C) $\mathrm{CNP}_{\mathrm{PtCP} / \mathrm{si} \text { (c-fos) }}$ for different time intervals. (D) Pt accumulation of tumor tissue after treatment with $\mathrm{CNP}_{\mathrm{PtCP} / \mathrm{si}(\mathrm{c}-\mathrm{fos})}$ for 12 and $24 \mathrm{~h}$ with or without light irradiation. "-" indicates in the dark, “+” indicates with irradiation. Light Source: $430 \mathrm{~nm}, 20 \mathrm{~mW} / \mathrm{cm}^{2}, 30 \mathrm{~min}$. 
A

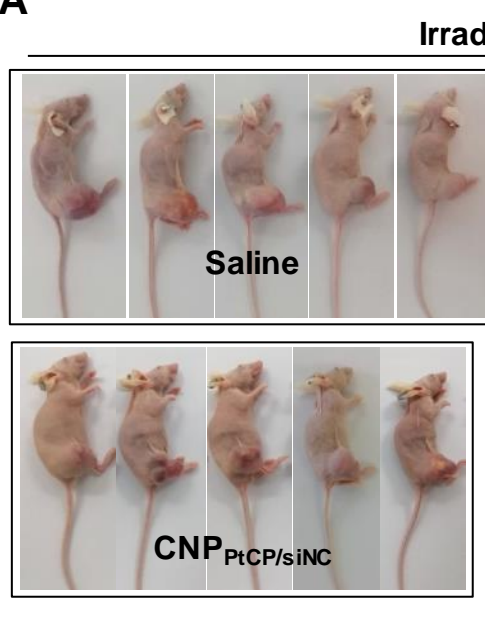

B

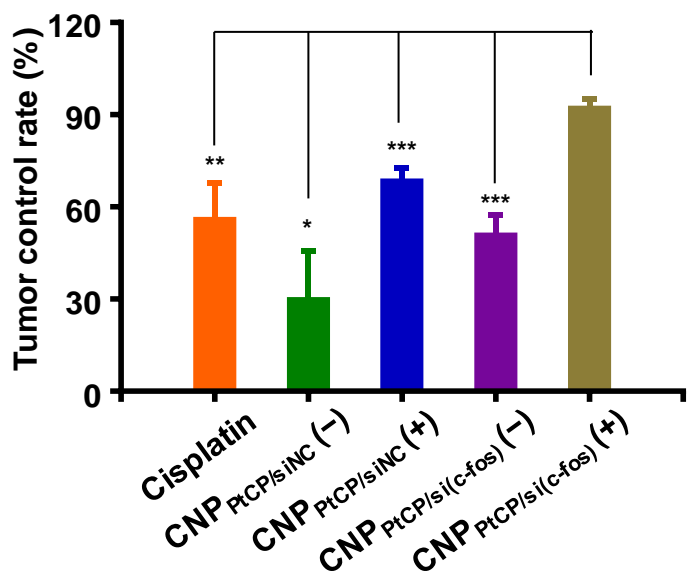

Cisplatin

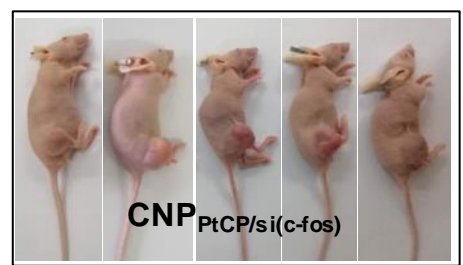

C
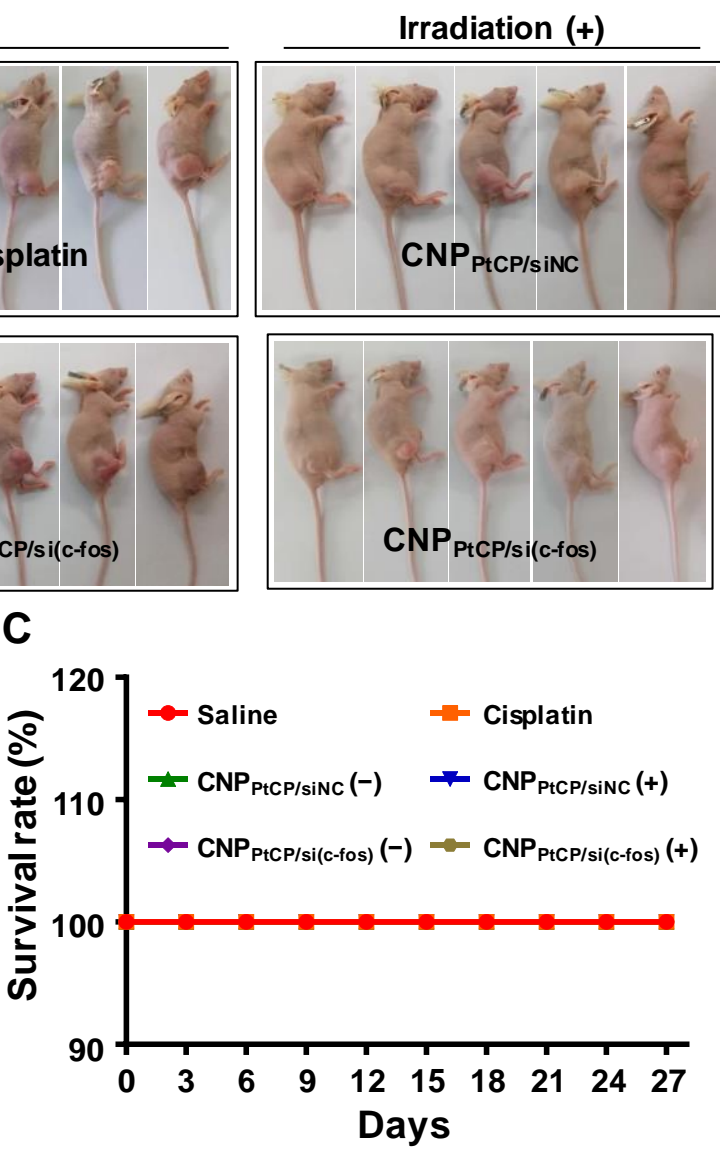

Figure S35. (A) The photographs of tumor-bearing nude mice at the end of the treatment. (B) Tumor control rates and (C) survival rates of different treatment groups. “-" indicated in the dark, "+" indicated with irradiation. Light source: $430 \mathrm{~nm}, 20$ $\mathrm{mW} / \mathrm{cm}^{2}, 30 \mathrm{~min}$. 
A
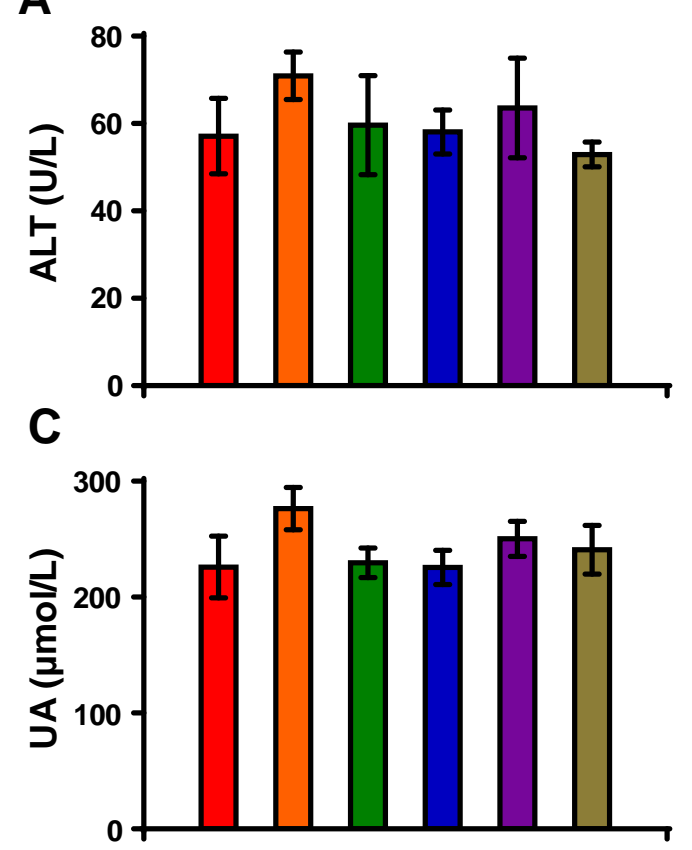

E

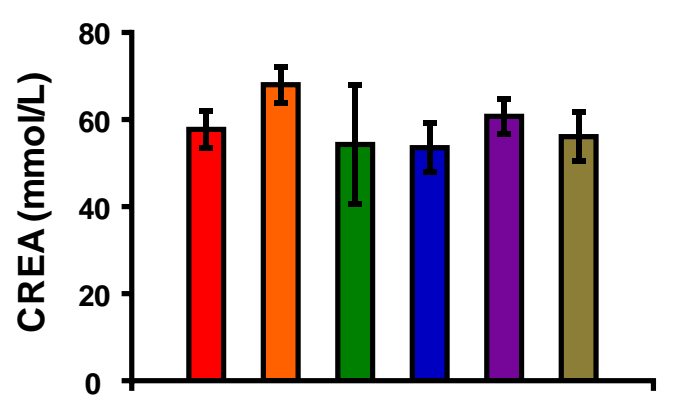

G

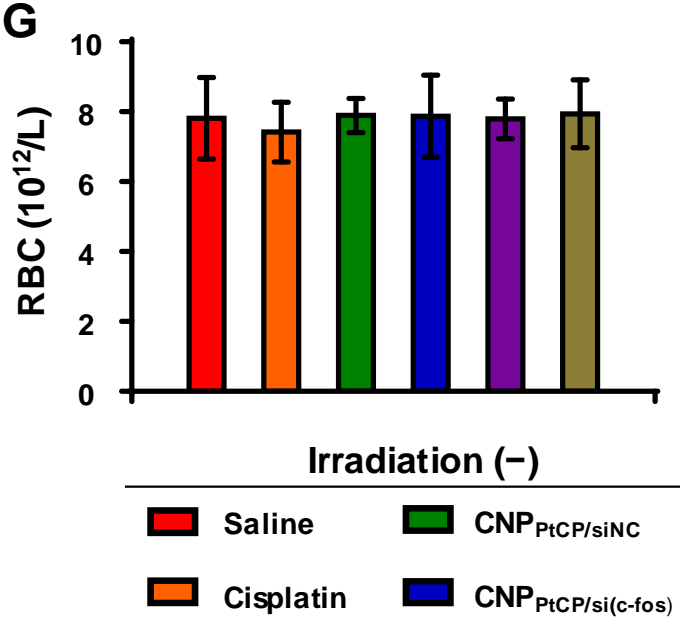

B
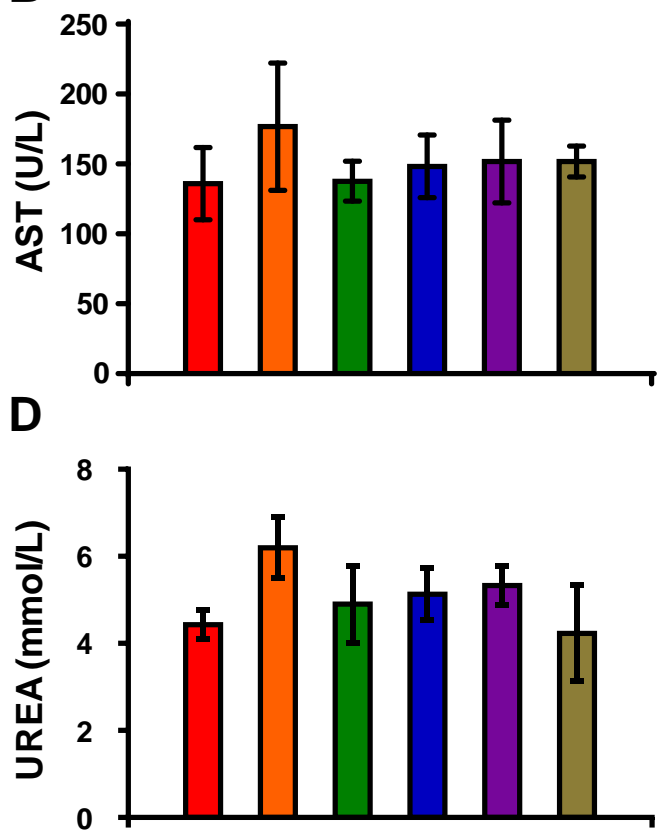

$\mathbf{F}$

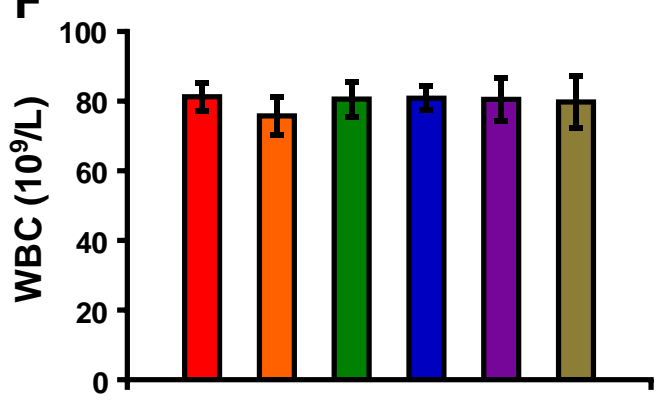

H
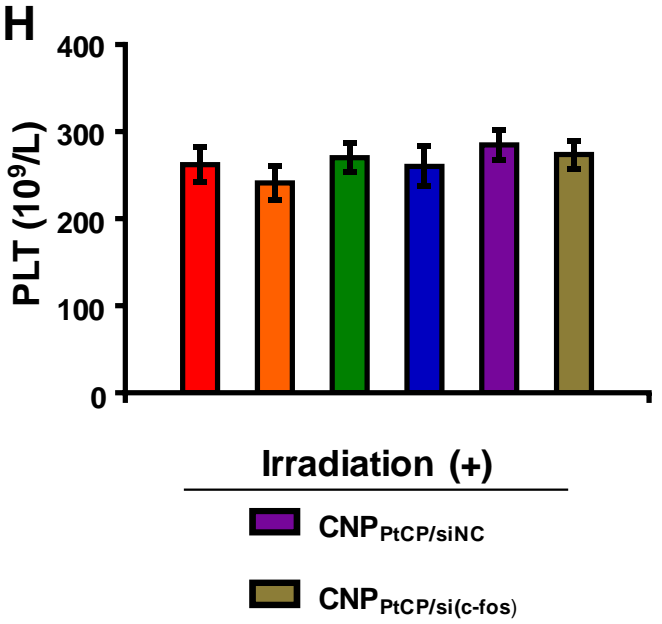

Figure S36. Blood biochemical analysis (A, B, C, D, E) and hematological analysis (F, G, H) of mice after different treatments. "-" indicated in the dark, "+" indicated with irradiation. Light source: $430 \mathrm{~nm}, 20 \mathrm{~mW} / \mathrm{cm}^{2}, 30 \mathrm{~min}$. 


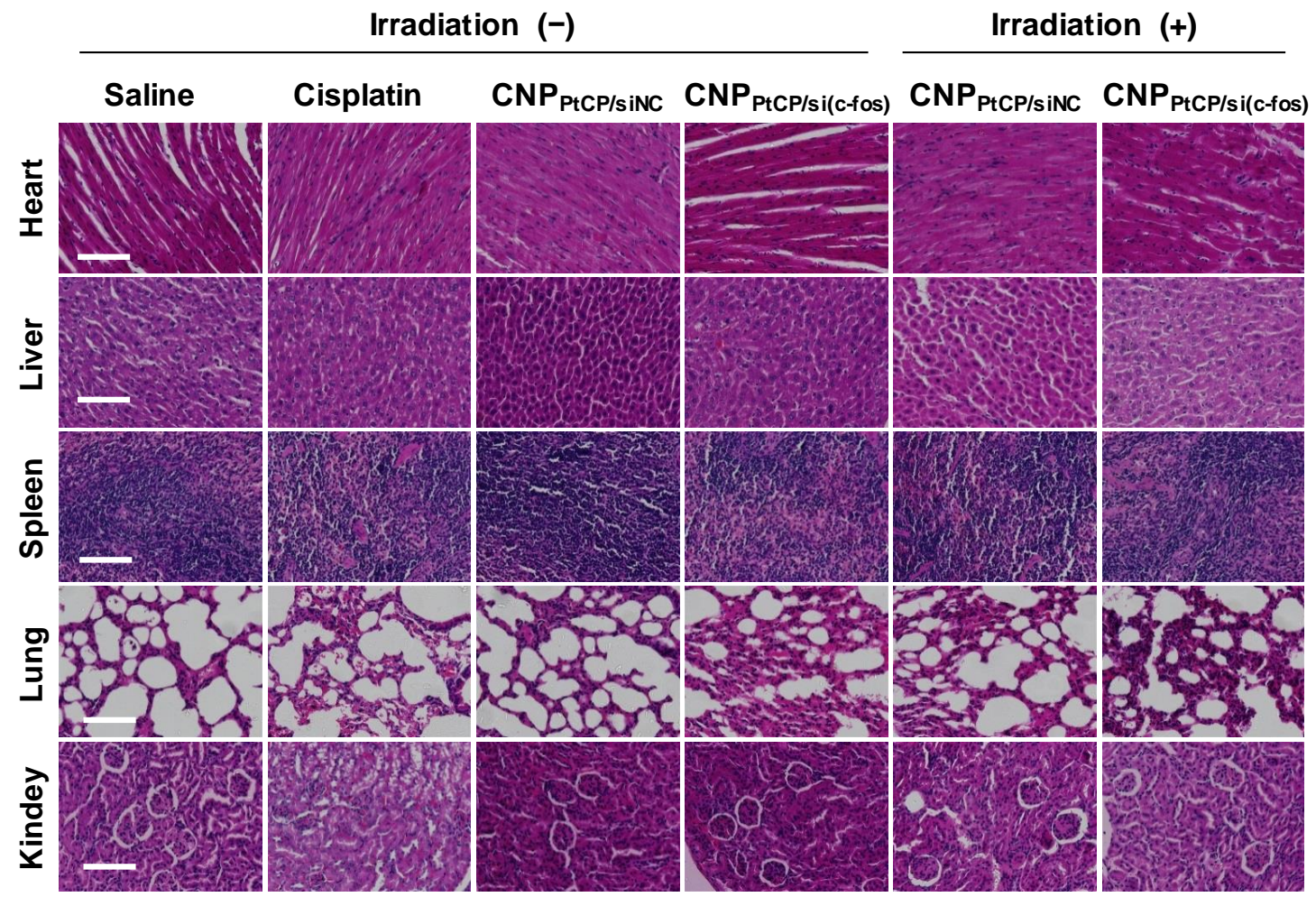

Figure S37. Histological assessment of the main organs with H\&E staining at the end of treatment. "-" indicated in the dark, “+” indicated with irradiation. Scale bar $=100$ $\mu \mathrm{m}$. Light source: $430 \mathrm{~nm}, 20 \mathrm{~mW} / \mathrm{cm}^{2}, 30 \mathrm{~min}$. 


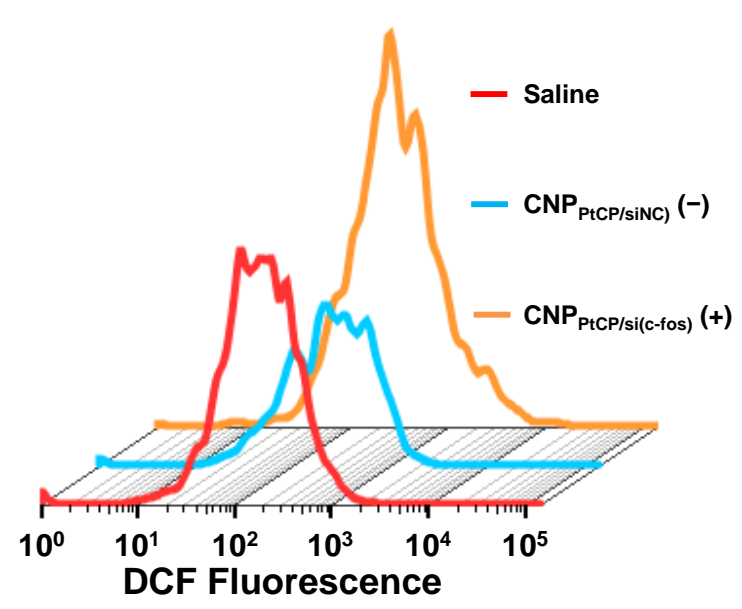

Figure S38. The oxidizing radical levels of tumor tissues analyzed by flow cytometry.

“-” indicated in the dark, “+” indicated with irradiation. Light source: $430 \mathrm{~nm}, 20$ $\mathrm{mW} / \mathrm{cm}^{2}, 30 \mathrm{~min}$. 

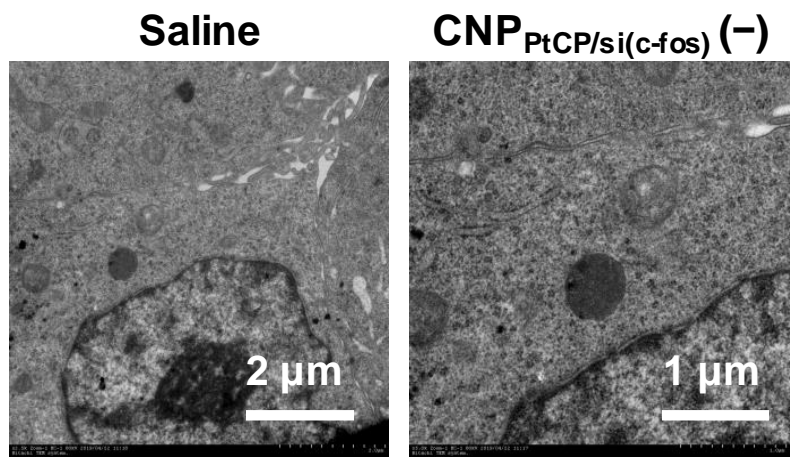

$\mathrm{CNP}_{\mathrm{PtCP} / \mathrm{si}(\mathbf{( - \text { fos }})(+)}$
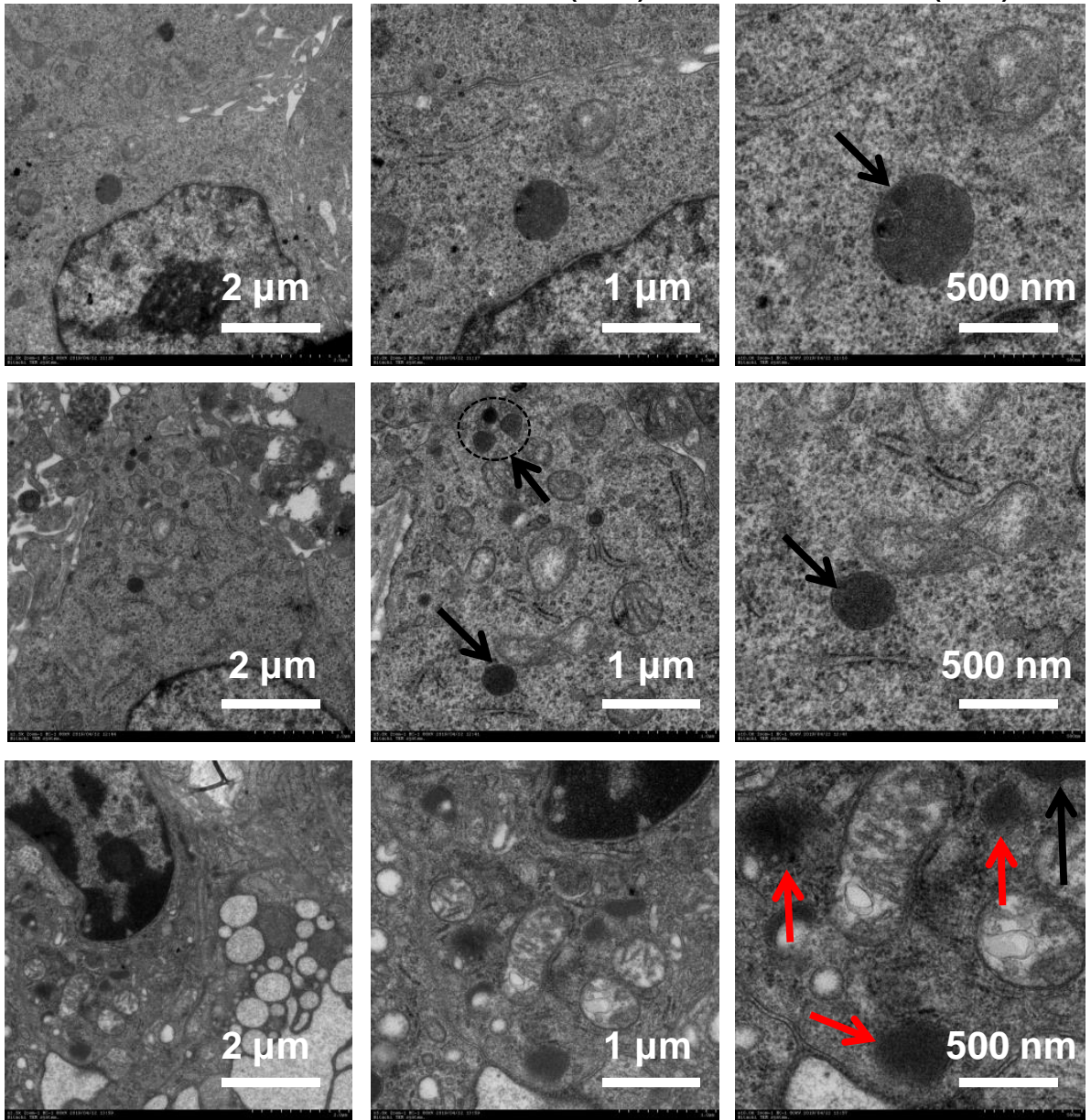

Figure S39. The intracellular endo/lysosomes of tumor tissues observed by TEM

(Black arrows: intact endo/lysosomes; Red arrows: damaged endo/lysosomes). “-” indicated in the dark, "+" indicated with irradiation. Light source: $430 \mathrm{~nm}, 20$ $\mathrm{mW} / \mathrm{cm}^{2}, 30 \mathrm{~min}$. 


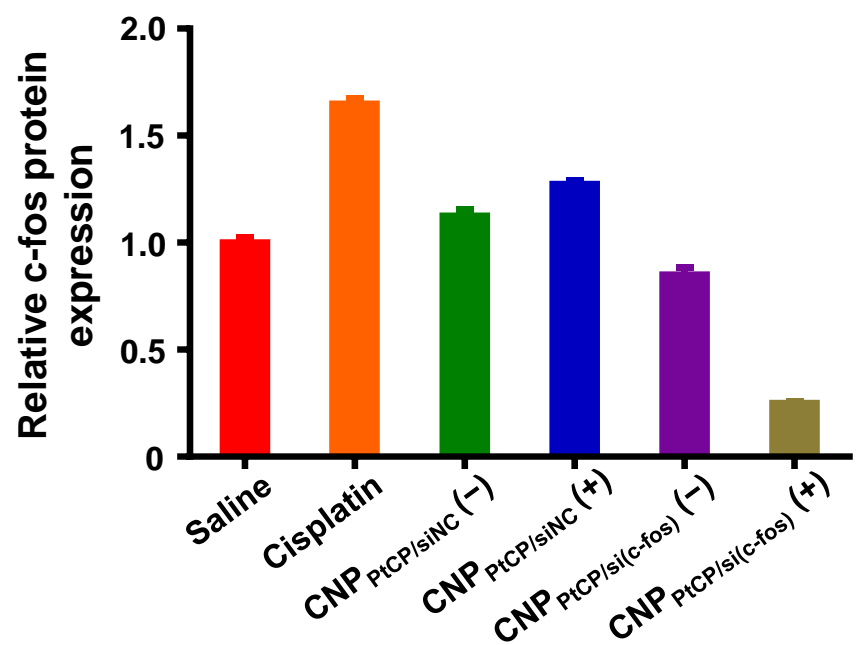

Figure S40. The relative c-fos protein expression levels of tumor tissues after different treatments measured by western blotting assay. "-" indicated in the dark, "+" indicated with irradiation. Light source: $430 \mathrm{~nm}, 20 \mathrm{~mW} / \mathrm{cm}^{2}, 30 \mathrm{~min}$. 
Table S1. Elemental analysis of Pt(IV)

\begin{tabular}{cc} 
& $\mathrm{Pt}(\mathrm{IV})$ \\
\hline $\mathrm{C}$ & $14.55^{\mathrm{a}} / 14.67^{\mathrm{b})}$ \\
$\mathrm{H}$ & $2.45^{\mathrm{a})} / 2.44^{\mathrm{b})}$ \\
$\mathrm{N}$ & $27.22^{\mathrm{a})} / 27.38^{\mathrm{b})}$ \\
\hline
\end{tabular}

${ }^{\text {a) }}$ Found value; ${ }^{\text {b) }}$ Calculated value. 
Table S2. ICP analysis of Pt content in Pt(IV), PtP and PtCP.

\begin{tabular}{cccc}
\hline & Pt(IV) & PtP & PtCP \\
\hline $\mathrm{Pt}$ & $47.52^{\mathrm{a})} / 47.68^{\mathrm{b})}$ & $30.12^{\mathrm{a})} / 31.98^{\mathrm{b})}$ & $16.80^{\mathrm{a})} / 20.44^{\mathrm{b})}$ \\
\hline
\end{tabular}

${ }^{\text {a) }}$ Found value; ${ }^{\text {b) }}$ Calculated value. 
Table S3. Characterization of PtP and PtCP.

\begin{tabular}{cccccc}
\hline Polymer & $\mathrm{Mn} / 10^{3}$ & $\mathrm{Mw} / 10^{3}$ & $\mathrm{PDI}$ & $\mathrm{DP}$ & $\mathrm{OEI}_{1.8 \mathrm{~K}}$ (Number) \\
\hline PtP & 63.4 & 70.7 & 1.11 & 104 & $/$ \\
$\mathrm{PtCP}$ & 99.2 & 113.1 & 1.14 & $/$ & 20 \\
\hline
\end{tabular}


Table S4. The conversion rates of $\mathrm{Pt}(\mathrm{IV})$ and $\mathrm{PtCP}$ after irradiation with different wavelength and time.

Conversion rates $=\left(A_{0}-A_{t}\right) /\left(A_{0}-A_{\infty}\right) * 100 \%$, in which $A_{0}, A_{t}$ and $A_{\infty}$ stand for the absorption value of $\mathrm{Pt}(\mathrm{IV})$ or $\mathrm{PtCP}$ after irradiation for $0, \mathrm{t}$ and totally degraded.

\begin{tabular}{cccc}
\hline \multirow{2}{*}{ Wavelength (nm) } & Time (min) & \multicolumn{2}{c}{ Conversion rates $(\%)$} \\
\cline { 3 - 4 } & & $\operatorname{Pt}(\mathrm{IV})$ & $\mathrm{PtCP}$ \\
\hline \multirow{3}{*}{365} & 10 & 29.0 & 39.8 \\
& 20 & 45.4 & 66.0 \\
& 30 & 56.2 & $/$ \\
\hline \multirow{2}{*}{430} & 10 & 20.9 & 29.1 \\
& 20 & 36.2 & 47.8 \\
& 30 & 48.7 & 61.0 \\
\hline \multirow{3}{*}{530} & 10 & 2.9 & 5.3 \\
& 20 & 4.9 & 9.1 \\
& 30 & 7.3 & 13.5 \\
\hline
\end{tabular}

